\title{
Effects of rainforest transformation systems on carbon cycle and soil fertility
}

\author{
Dissertation \\ to obtain the $\mathrm{Ph}$. D. degree \\ in the International Ph. D. Program for Agricultural Sciences in Goettingen (IPAG) \\ at the Faculty of Agricultural Sciences, \\ Georg-August-University Göttingen, Germany
}

presented by

Thomas Guillaume

born in Lausanne, Switzerland

Göttingen, October 2015 
Supervisor: Prof. Dr. Yakov Kuzyakov. Department of Soil Science of Temperate Ecosystems, and Department of Agricultural Soil Science, Georg-August-University of Göttingen

Co-supervisor: Prof. Dr. Daniela Sauer. Department of Physical Geography, Georg-AugustUniversity of Göttingen

Examiner: Prof. Dr. Dirk Hölscher. Department of Tropical Silviculture and Forest Ecology, Georg-August-University of Göttingen 


\section{Table of Contents}

\section{Contents}

I Table of Contents............................................................................................................................. i

II List of Figures ............................................................................................................................. iv

III List of Tables.............................................................................................................. vi

IV Abbreviations .................................................................................................................................... vii

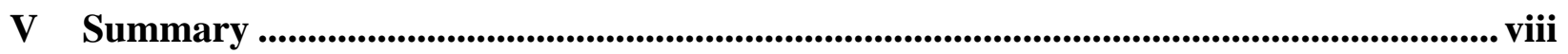

1 General Introduction............................................................................................................... 1

2 Objectives and Methodology ....................................................................................................... 6

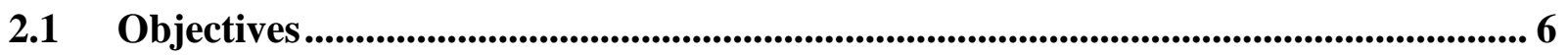

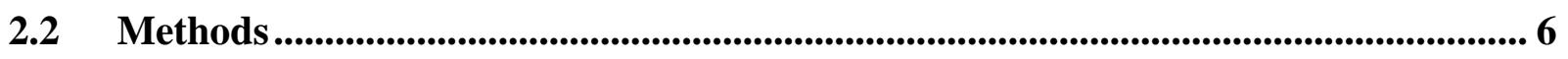

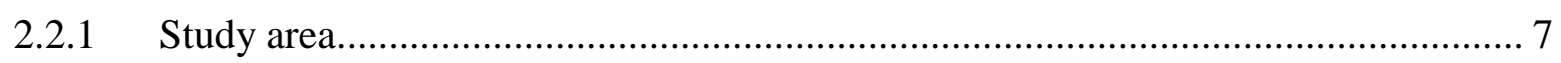

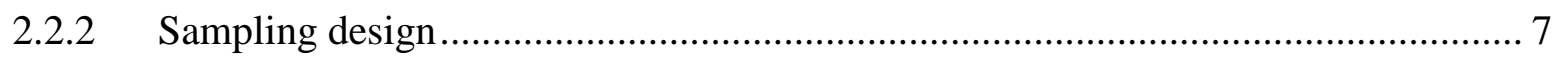

3 Publications and Manuscripts ................................................................................................. 10

3.1 Study 1 Soil degradation in oil palm and rubber plantations under land resource scarcity .................................................................................................................................... 10

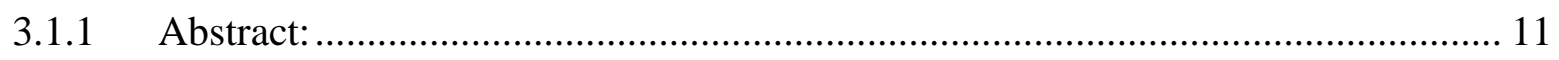

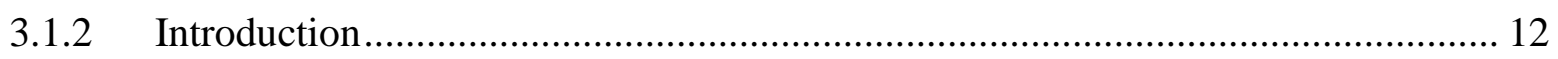

3.1.3 Materials and Methods.............................................................................. 14

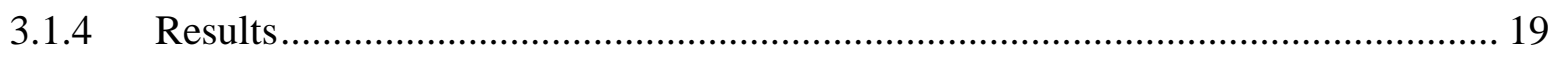

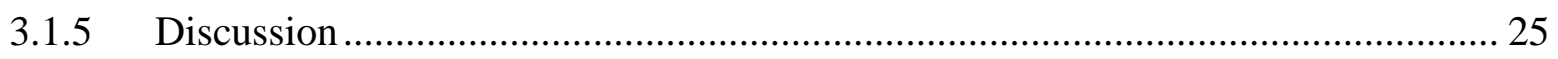

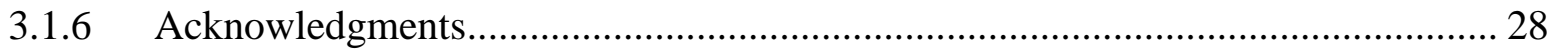

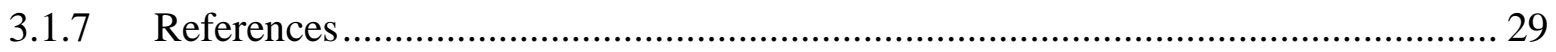

3.2 Study 2 Losses of soil carbon by converting tropical forest to plantations: Erosion and decomposition estimated by $\delta^{13} \mathrm{C}$..........................................................................3 34

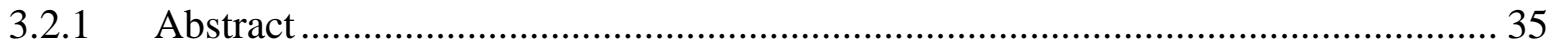




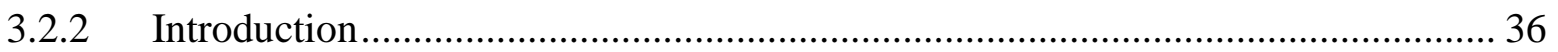

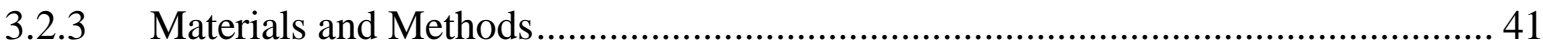

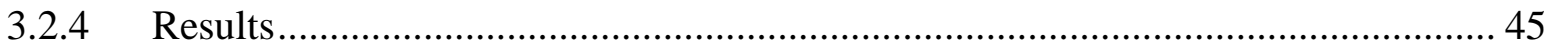

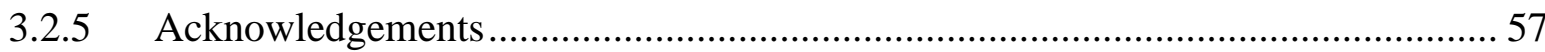

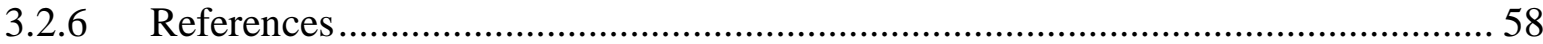

3.3 Study 3 New approach for sensitivity of soil fertility indicators to land-use changes: Theory and examples from conversion of Indonesian rainforest to plantations ..

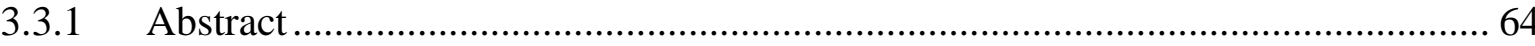

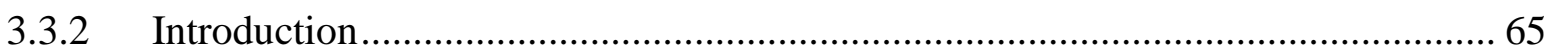

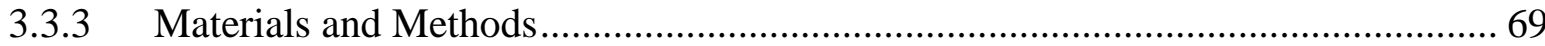

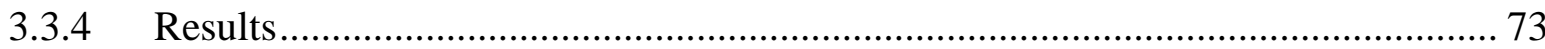

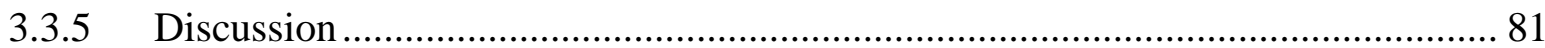

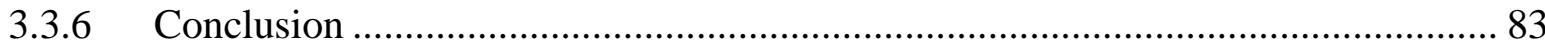

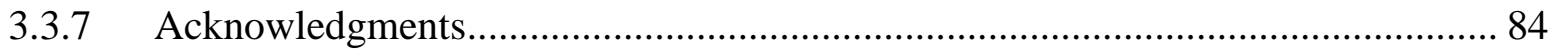

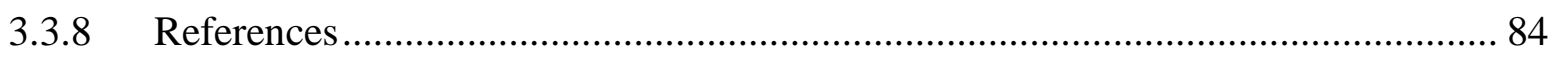

4 Additional Studies............................................................................................................ 92

4.1 Study 4 Chemical characterization of soil organic matter ............................................ 92

4.1.1 Fourier transform infrared spectroscopy ………................................................ 92

4.1.2 Excitation-emission fluorescence spectroscopy …………………………........... 95

4.1.3 Rock-Eval pyrolysis ...................................................................................... 98

4.2 Study 5 Microbial response to easily available $C$ input............................................... 101

4.3 Study 6 Carbon translocation between topsoil and subsoil by dissolved organic matter ................................................................................................................................................................. 107

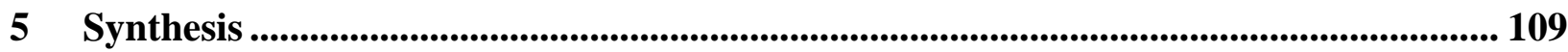

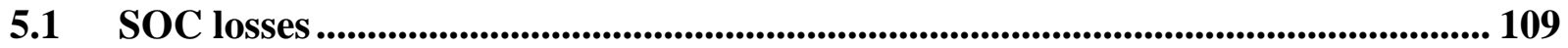

5.2 Soil fertility............................................................................................................................ 114

5.3 Is oil palm the worst? .......................................................................................................... 116

6 References.................................................................................................................................... 118

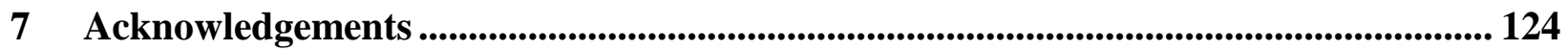

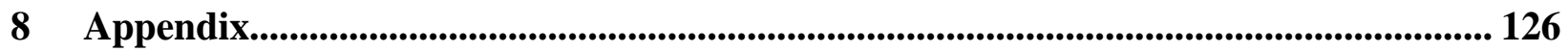




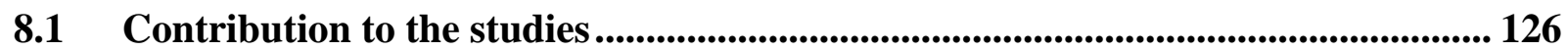

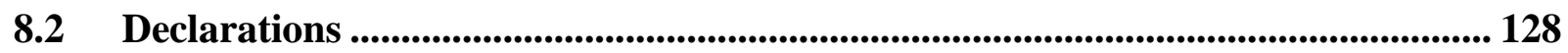

8.3 Curriculum vitae ........................................................................................................... 129 


\section{List of Figures}

Figure 1-1: Land-use types in Jambi province (Sumatra) ................................................. 2

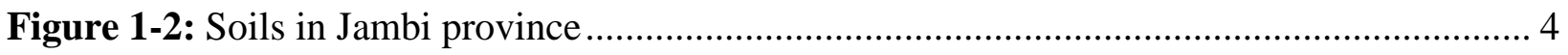

Figure 2-1: Schematic overview of the problematics, general objectives and aims of single studies. 9

Figure 3-1: Map of the Jambi province with the proportion of rubber and oil palm adoption by farmers in the selected villages. 15

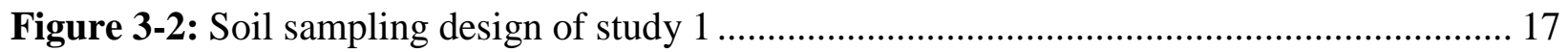

Figure 3-3: C content distribution of the 207 plantations...................................................... 19

Figure 3-4: Distributions of $\mathrm{C}$ content and bulk density in mineral soils under three land-use types: extensive and intensive rubber, and oil palm plantations.

Figure 3-5: Distributions of $\mathrm{C}$ content and bulk density in mineral soils under intensive rubber and oil palm plantations in regencies of Muaro Jambi and Batanghari. 22

Figure 3-6: Heterogeneity of soil properties within oil palm plantations. 23 Figure 3-7: Impact of forest conversion on the $\mathrm{C}$ content and $\delta^{13} \mathrm{C}$ distributions in the soil depths (ab); separated by decomposition (a) and erosion (b). 37

Figure 3-8: Carbon and nitrogen contents in the Ah horizons under (Fo) forest, (JR) jungle rubber, $(\mathrm{Ru})$ rubber and $(\mathrm{OP})$ oil palm plantations in Harapan and Bukit regions. 45

Figure 3-9: Soil characteristic distributions with soil depth. 46

Figure 3-10: Soil erosion in the four replicate soils under jungle rubber, rubber and oil palm plantations in Harapan region. 49

Figure 3-11: Relation between $\delta^{13} \mathrm{C}$ and the logarithm of $\mathrm{C}$ content. ................................... 51

Figure 3-12: Effect of erosion and decomposition on the $\mathrm{C}$ content and the $\delta^{13} \mathrm{C}$ of the $\mathrm{Ah}$ horizons under rubber and oil palm plantations, depending on the $\mathrm{C}$ input from leaf litter........ 56

Figure 3-13: Concept of sensitivity of soil fertility indicators to SOC losses (or other main variables) by land-use changes.

Figure 3-14: Decrease of soil fertility indicators per land-use type .................................... 74

Figure 3-15: Sensitivity of microbial activity indices by land-use type............................... 76 
Figure 3-16: Logarithmic relationship between basal respiration and $\mathrm{C}$ content. 77

Figure 3-17: Sensitivity of soil fertility indicators to SOM losses (a, b) and the coupling of indictors with basal respiration $(\mathrm{c}, \mathrm{d})$. 78

Figure 4-1: Comparison of absorption spectrums obtained by ATR and Trans modes on the same sample (Ah horizon of the forest site BF2). 93

Figure 4-2: SOM recalcitrance measured by aliphatic / aromatic ratio .................................. 94

Figure 4-3: Comparison of absorption spectrums obtained by Trans and DRIFT mode. 95

Figure 4-4: Location of EEM peaks and their associated organic compounds separated in five regions. 96

Figure 4-5: EEMs of DOM and WEDOM from the topsoil and subsoil of the forest site HF2.. 97

Figure 4-6: Principal component analysis on the Ah horizon from the four land-use types in Harapan region separated by variables obtained from the RE pyrolysis.

Figure 4-7: Experimental design of the incubation, describing the treatments and measurements done at three time points. 101

Figure 4-8: Respiration rates during the first 20 days of soil incubation. ............................. 103

Figure 4-9: Recovery of ${ }^{14} \mathrm{C}$ in SOM pools. 104

Figure 4-10: Substrate induced respiration (cumulative C-C02) during 24 hours after substrate addition. 105

Figure 4-11: $\mathrm{K}_{2} \mathrm{SO}_{4}$-extractable DOC after 8, 71 and 156 days of incubation of soils under forest (Fo), jungle rubber (JR), oil palm (OP) and rubber $(\mathrm{Ru})$ plantations. 106

Figure 4-12: Yearly average of DOC concentration in the top soil and subsoil under forest, jungle rubber, rubber and oil palm plantations. 108

Figure 5-1: Aboveground and belowground carbon stocks in forest (Fo), jungle rubber (JR), rubber $(\mathrm{R})$ and oil palm (OP) plantations. 109

Figure 5-2: Synthesis of the main findings. 111

Figure 5-3: Net primary production in the land-use types. 115 


\section{List of Tables}

Table 2-1. New approaches developed in the thesis .......................................................... 8

Table 3-1. Soil properties under extensive rubber (ER), intensive rubber (IR) and oil palm (OP)

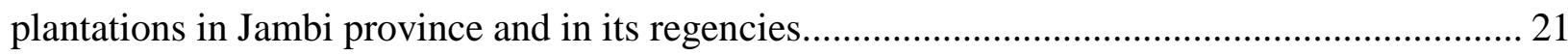

Table 3-2. Carbon stocks $\left(\mathrm{Mg} \mathrm{C} \mathrm{ha}^{-1}\right)$ in four land-use types of Harapan and Bukit regions...... 47 Table 3-3. Parameters of the fitted power functions of $\mathrm{C}$ content and $\delta^{13} \mathrm{C}$ with depth in forest

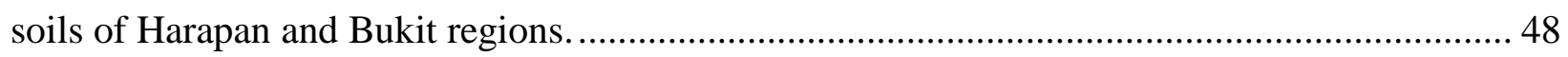

Table 3-4. Average parameters of the linear regression of $\delta^{13} \mathrm{C}$ with the log-transformed $\mathrm{C}$ content per land-use type in Harapan region. ................................................................... 50

Table 3-5. Soil properties and processes under forest, extensive rubber plantations (jungle

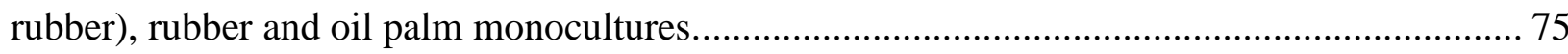

Table 3-6. Linear and non-linear regressions between indicators and SOM as independent variable, and between the basal respiration and indicators as independent variables. 79 


\section{Abbreviations}

$\begin{array}{ll}\text { BasResp/BR: } & \text { basal respiration } \\ \text { Cmic: } & \text { microbial biomass } \\ \text { CUE: } & \text { Carbon use efficiency } \\ \text { DOC: } & \text { Dissolved organic carbon } \\ \text { DOM: } & \text { Dissolved organic matter } \\ \text { EEM: } & \text { greenhouse gas emission } \\ \text { GHGE: } & \text { light fraction } \\ \text { LF: } & \text { Net primary production } \\ \text { NPP: } & \text { acid phosphatase activity } \\ \text { Phos: } & \text { Substrate induced respiration } \\ \text { SIR: } & \text { soil organic carbon } \\ \text { SOC: } & \text { soil organic mater } \\ \text { SOM: } & \text { water extractable dissolved organic matter } \\ \text { WEDOM: } & \end{array}$

$\underline{\text { Site acronyms: }}$

First letter: region; $\mathrm{H}=$ Harapan / B = Bukit

Second letter: land-use type; $\mathrm{F}=$ forest $/ \mathrm{J}=$ jungle rubber $/ \mathrm{O}=$ oil palm $/ \mathrm{R}=$ rubber

Number: replicate site 


\section{Summary}

Agriculture faces the challenge of producing, in the first half of the 21st century, a similar amount of calories to those produced during the last 400 years, while also reducing its negative environmental impacts, such as greenhouse gas emissions and soil fertility losses. Agricultural intensification in the tropics has been achieved at the expense of rainforest. Thus, tropical regions such as Sumatra, that have experienced extensive deforestation in the past, are close to a complete exhaustion of easily accessible forest. Jambi Province, located in Central Sumatra, has experienced a four-fold increase of the area under oil palm plantation in the last 20 years. Landuse changes in tropical ecosystems leads to major modifications of biogeochemical cycles. The decrease of soil organic carbon (SOC) following the conversion of natural forest to plantations raises major concerns about soil functions that regulate global climate and support plant growth. This thesis aims at assessing the impacts of land-use changes in a tropical region suffering from land scarcity on two soil functions provided by SOC; C sequestration and soil fertility.

In a survey of randomly-selected plantations over the Jambi province, the soil degradation under rubber plantations of various land-use intensities and oil palm plantations was assessed by measuring the $\mathrm{C}$ and $\mathrm{N}$ content, and bulk density in the topsoil. The $\mathrm{C}$ content under rubber plantations was half of the $\mathrm{C}$ content under forests in Jambi province. On average, soils under oil palm were more degraded than under rubber plantations. Because the oil palm boom started when the lowland of Jambi province had already experienced extensive deforestation, oil palm plantations were frequently established either on soils degraded by previous use or on peat soils and in riparian areas. Nevertheless, the structure and management of oil palm plantations led to a further degradation between oil palms row and trees.

In order to separate the land-use effect from the history of the plantations, SOC losses were quantified in a space-for-time substitution approach with forest sites as references. SOC losses under plantations were strong in the topsoil. Dissolved organic carbon concentrations under oil palm were higher than under other land-uses, but no differences in SOC were observed in the subsoil of any of the plantation types. The SOC losses in the topsoil were highest under rubber 
and oil palm monocultures. Due to low ground protection from canopy and litter layers, soil erosion, estimated by a shift of $\delta^{13} \mathrm{C}$ values in the subsoil of plantations, was especially high in these two intensive plantations. According to the ${ }^{13} \mathrm{C}$ enrichment of SOC, the SOC turnover was not affected by forest conversion to rubber plantations. Therefore, the SOC stocks decreased because of reduced $\mathrm{C}$ input from the vegetation in rubber plantations, and of additional erosional losses in rubber monocultures. The ${ }^{13} \mathrm{C}$ enrichment of SOC suggested that the turnover was slower under oil palm plantations due to a depletion of the labile SOM pool resulting from the absence of leaf litter input.

The decrease of SOM availability under plantations, and especially oil palm, was confirmed by various techniques. Not only was the quantity of labile pools, such as dissolved organic carbon or the light fraction, lower, but also the quality of SOM. The latter was assessed by the aliphatic/aromatic ratio, the H/C ratio or the SOM thermal stability. The decrease of SOM availability was indicated by a decrease of microbial activity under plantations. Nonetheless, the microbial activity was resistant to the decrease of SOM and labile pools. The resistance of microbial activity showed a threshold at a $\mathrm{C}$ content similar to the average $\mathrm{C}$ content under intensive rubber plantations where microbial activity decreased faster than the SOC losses. Despite that the mechanisms leading to this resistance have not been assessed yet, the nutrient enrichment of SOM under plantations could support microbial activity up to a threshold where C becomes the limiting factor.

In conclusion, forest conversion to plantation led to a strong decrease of SOC in the topsoil. However, the SOC losses were relatively small in comparison to the $\mathrm{C}$ losses from the plant biomass. Nevertheless, the decrease of SOC had strong impacts on all indicators of soil fertility (microbial biomass, basal respiration, phosphatase activity, DOC, light fraction, SOM chemical and thermal stability, $\mathrm{N}$ content and available $\mathrm{P}$ ). The level of soil degradation in Jambi province and the establishment of new plantations on soils with high SOC stocks are raising major concerns about the sustainability of agricultural intensification in the tropics. Therefore, management practices should be improved to mitigate soil erosion and provide higher $\mathrm{C}$ input from the biomass in order to maintain soil functions. 


\section{General Introduction}

\section{Agricultural intensification}

The global demand for agricultural products such as food, feed, fibers and biofuel is projected to increase strongly in the coming decades, driven mainly by population growth, change in diet and increasing incomes (Tilman et al., 2001; Garnett et al., 2013; Keating et al., 2014). To respond to this increasing demand, agriculture faces the challenge of producing, in the first half of the 21 st century, the same amount of calories that was produced during the last 400 years (Keating \& Carberry, 2010). Simultaneously, agriculture must reduce its negative environmental impacts, such as greenhouse gas emissions, degradation of ecosystem fertility and biodiversity losses.

\section{Deforestation in Indonesia}

During the "green revolution", food production was doubled by improving crop varieties, intensifying land use and converting natural ecosystems into agroecosystems (Stevenson et al., 2013). Between 1980 and 2000, agricultural land increased by more than 100 million ha in tropical regions. This expansion was mostly achieved at the expense of intact (55\%) or disturbed (28\%) tropical forests (Gibbs et al., 2010). Although Brazil has been the historical leader of tropical deforestation, the last decade showed a decreasing trend of the deforestation rate there (Hansen et al., 2013). In contrast, deforestation continues to accelerate in Indonesia, which became the world leader of deforestation in 2012 (Margono et al., 2014). The three biggest Indonesian islands (Kalimantan, Sumatra and Papua) have experienced varying degrees of ecosystem transformation. With only $9 \%$ of lowland forest cover left in 2012, Sumatra is at the final stage of natural ecosystem transformation, when easily accessible forest have been transformed and new agricultural land is established in marginal areas, such as mountain or wetland forests. Between 2000 and 2012, forest losses were higher in wetlands than in lowlands on Sumatra (Margono et al., 2014). The near exhaustion of accessible forested land is also indicated by the fact that the new industrial concessions in forested area are five times smaller in Sumatra compared to in Kalimantan and Papua (Abood et al., 2015). In contrast, deforestation is 
only at a nascent stage in Papua, where forests still cover $86 \%$ of the island. Forest losses in absolute or relative values, and the ratio of forest losses in wetland and lowland decrease in the same order: Sumatra > Kalimantan > Papua (Margono et al., 2014). The main drivers of deforestation in Indonesia are the pulp, timber, mining, rubber and oil palm industries (Abood et al., 2015). Indonesia is the second largest producer of natural rubber (3.5 million ha) and the largest producer of oil palm (7.1 million ha) in the world (FAOSTAT). Smallholder farmers account for $40 \%$ of the oil palm production and almost all of the rubber production in Indonesia (Euler et al., 2015). The pressure on Indonesian forest will continue to increase because the Indonesian government is planning to reach a target of 18 million hectares under oil palm cultivation by 2020 (Tarigan et al., 2015).

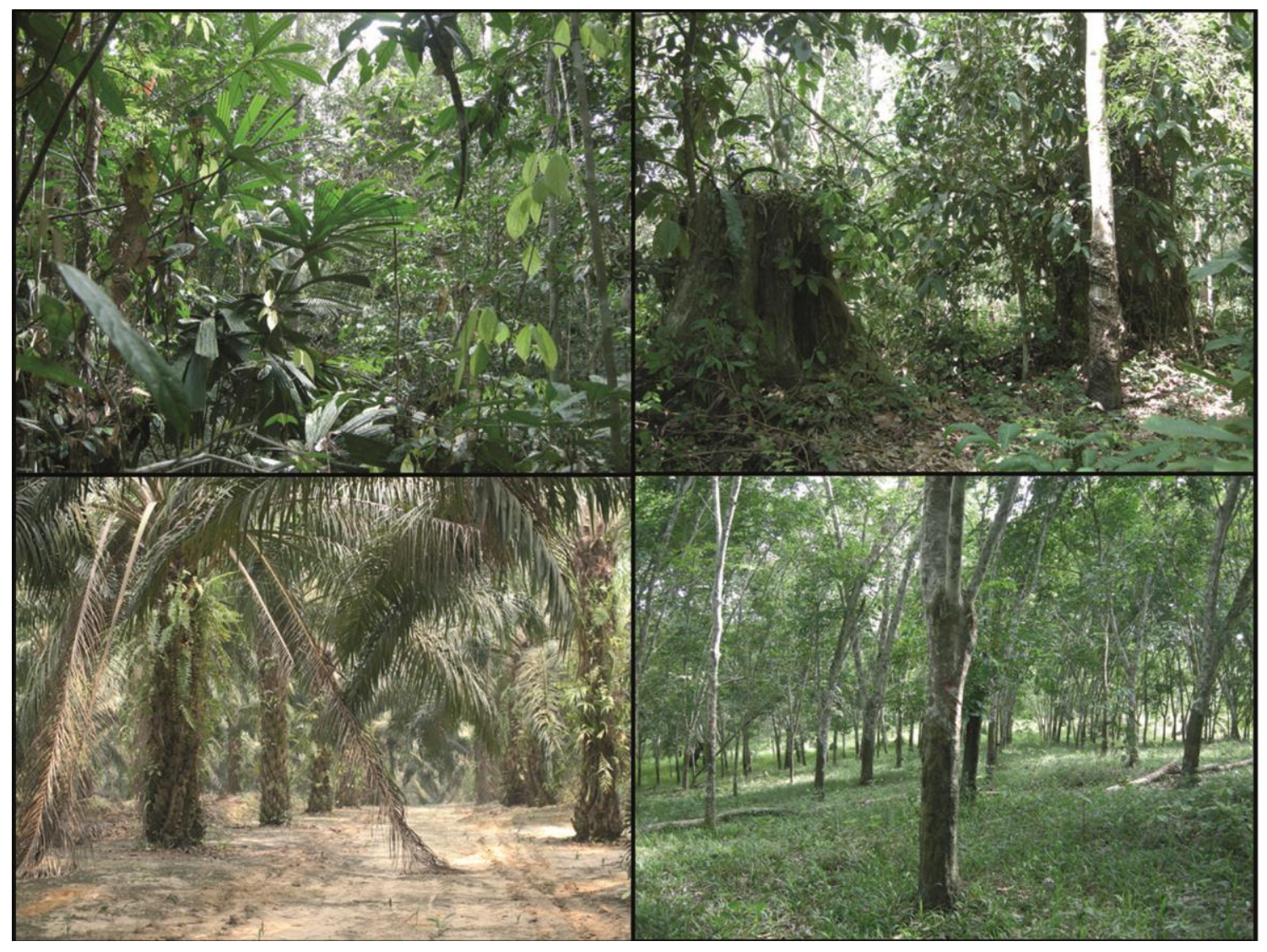

Figure 1-1: Land-use types in Jambi province (Sumatra)

Forest (top left), jungle rubber (top right), oil palm (bottom left) and rubber (bottom right) monocultures 


\section{Functions of soil organic carbon}

In the last decades land-use changes have been associated with extensive soil degradation (Amundson et al., 2015), resulting in a decrease of the soil functions that provide ecosystem services (Haygarth \& Ritz, 2009). Among the various soil properties affected by land-use change, the decrease of soil organic carbon (SOC) raises major concerns about soil functions that regulate global climate and support plant growth. With $2300 \mathrm{Gt} \mathrm{C}$ in the uppermost $3 \mathrm{~m}$, SOC is the largest terrestrial C pool in exchange with the biological $(560 \mathrm{Gt})$ and atmospheric $(760 \mathrm{Gt})$ C pools (Jobbágy \& Jackson, 2000; Lal, 2004). Thirty percent of the world's total SOC is stored in tropical soils (Jobbágy \& Jackson, 2000). Therefore, a small decrease of the tropical SOC pool can significantly contribute to the increase of the atmospheric $\mathrm{CO}_{2}$ concentration. However, because the effect on SOC stocks of tropical forest conversion to perennial crops remains unclear, the soil $\mathrm{CO}_{2}$ emissions are not included when budgeting the greenhouse gas emissions resulting from this land-use change (Lasco et al., 2006). Indeed, despite the large-scale extension of rubber and oil palm plantations, studies on these land-use types are underrepresented in the literature compared to studies on forest conversion to pasture or cropland (Powers et al., 2011).

SOC is associated with most properties and functions related to soil fertility. Indeed, the chemical energy stored in the covalent bonds between $\mathrm{C}$ atoms of the soil organic matter (SOM) and plant litter is the primary energy resource for organisms involved in nutrient recycling and soil structuration. Additionally, C is the main element (around 50\%) of SOM and forms the molecular frameworks on which SOM nutrients are bound. Furthermore, SOM adsorbs nutrients and so prevents nutrient losses by leaching. Nutrient recycling between the biomass and the SOM is a critical process in heavily-weathered soil because of the low nutrient concentration of the soil mineral matrix. Indeed, the main limiting factor of the primary production and SOM decomposition in tropical forests is phosphorus (Vitousek, 1984; Cleveland et al., 2006). Finally, the positive effect of SOM on soil structure reduces erosion and increases water storage, water filtration and groundwater recharge (Bronick \& Lal, 2005). Consequently, SOC is considered as an "umbrella" property of soil fertility because a decrease in SOC results in a decrease of the other properties that influence soil fertility. Finally, SOM is positively correlated with crop yield (Lal, 2006). 


\section{Mechanisms of SOC losses}

Similarly to any pool, a disequilibrium of the SOC pool results from unbalanced C inputs and outputs. Even though old-growth forest soils can act as a C sink in the long-term (Zhou et al., 2006), SOC under forest is considered to be in a steady state over time scales relevant for landuse changes (decades). Because of a high SOC turnover in the tropics, SOC pools react quickly to any changes in biophysical conditions subsequent to land-use change (Trumbore, 1993). The majority of SOC losses after tropical forest conversion to rubber or oil palm plantations happen during the first 5 to 10 years and the SOC pool is close to equilibrium around 20 years after conversion (de Blécourt et al., 2013; van Straaten et al., 2015).

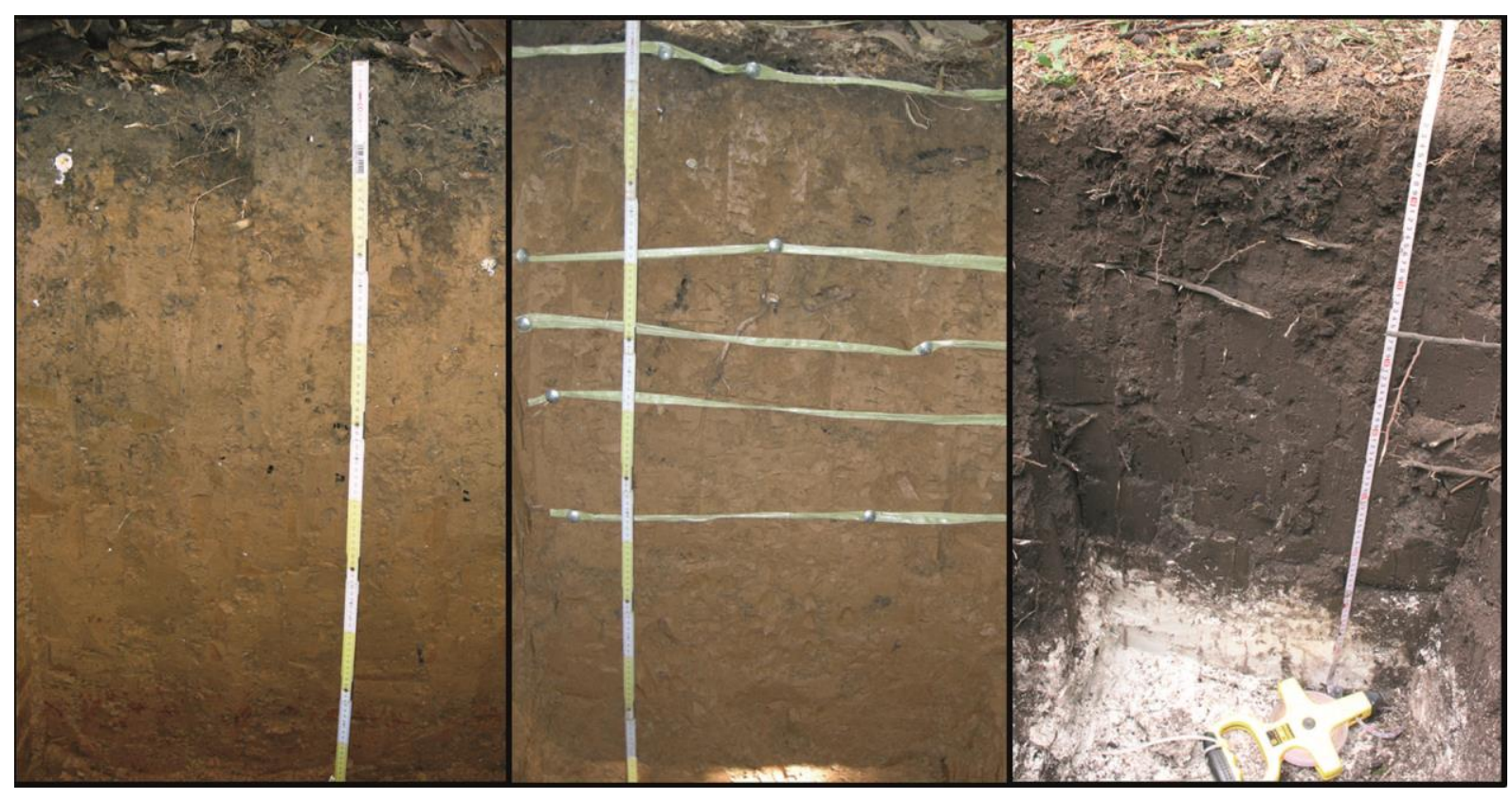

Figure 1-2: Soils in Jambi province

Left: loam Acrisol (plot HR2); Middle: clay Acrisol (plot BJ3); Right: mineral soil with high C content (12\% in the top $5 \mathrm{~cm}$ ) in riparian area (bottom slope in plantation PTPN6)

The decrease of SOC after land-use change occurs by a combination of various mechanisms. Firstly, the $\mathrm{C}$ input to the soil is generally lower in agroecosystems. For instance, the net primary production (NPP) remaining in oil palm and rubber plantations after harvesting is reduced by $50 \%$ in both plantation types, relative to natural forest. All compartments (litter production, root production, stem production) are affected similarly (Kotowska et al., 2015). However, in contrast to rubber plantations, the leaf litter $\mathrm{C}$ input is not spread homogenously in oil palm plantations. 
Instead, dead leaves are piled in specific locations. Consequently, the soil receives a negligible amount of aboveground $\mathrm{C}$ input in most of the oil palm plantation area. Secondly, the SOC decomposition rate can be enhanced by 1) an increase of nutrient availability either from biomass burning and decomposition during the plantation establishment or from fertilization during plantation maturation, or 2) an increase of SOC availability due to a decrease of physical protection following, for instance, aggregate destabilization (Six et al., 2002). Finally, SOC can be exported from the agroecosystem by soil erosion or dissolved organic C (DOC) leaching (Lal, 2001).

\section{Challenges related to SOC losses}

In order to sustain or increase agricultural production, agroecosystem resource-use efficiency must be enhanced to avoid a negative feedback on production due to the decrease of SOC (Keating et al., 2010). Therefore, quantifying SOC losses due to land-use changes and understanding the processes involved are the initial steps to improve management practices in order to increase agroecosystem efficiency. Nonetheless, these initial steps are not sufficient to motivate stakeholder adoption of new management practices. Their costs and benefits have to be evaluated in the same balance alongside the socio-economic costs and benefits. In order to achieve this goal, 1) changes in SOC have to be quantitatively related to the changes in functions, 2) functions have to be quantitatively related to socio-economic costs and benefits, and 3) efficient methods to monitor the impacts of land-use change have to be developed in order to evaluate management practices in a routine way 


\section{Objectives and Methodology}

\subsection{Objectives}

This thesis aims to assess the functions of SOC in tropical agroecosystems and the function resistance to lowland rainforest conversion to rubber and oil palm plantations. Because of the multiple functions associated with SOC, the thesis focuses on the $\mathrm{C}$ sequestration and soil plant growth supporting functions. We hypothesized that SOC would decrease in the topsoil after forest conversion due to an increase of SOC decomposition rate and soil erosion. However, SOC would accumulate in the subsoil because of an increase of dissolved organic carbon leaching. SOC losses in the topsoil would be associated with a decrease of soil fertility and plantation productivity. Finally, biological indicators of soil fertility would be more sensitive to SOC losses than chemical indicators.

Therefore, the objectives were the following:

(1) To determine the extent of soil degradation (SOC losses and soil compaction) under rubber and oil palm at the plantation and regional scales

(2) To quantify SOC losses after forest conversion to oil palm and rubber plantations

(3) To identify the mechanisms involved in SOM losses

(4) To assess the SOM availability for microorganisms after forest conversion

(5) To quantify the sensitivity of indicators of soil fertility to SOM losses

(6) To quantify the impact of soil degradation on plantation productivity

\subsection{Methods}

The research was integrated in the collaborative research center (CRC 990): "Ecological and Socioeconomic Functions of Tropical Lowland Rainforest Transformation Systems (Sumatra, Indonesia)". According to the funding proposal, the project aimed at "providing knowledgebased guidelines on how to protect and enhance the ecological functions and services of tropical 
forests, forest remnants and agricultural transformation systems at a landscape scale, while improving human welfare at the same time". The project consisted in 24 subprojects divided in three groups: environmental processes (group A), biota and ecosystem services (group B) and human dimensions (group C). The variety of scientific disciplines in this project was a unique opportunity to establish links between soil properties and their functions for human welfare.

\subsubsection{Study area}

The research was conducted in Jambi province (Sumatra, Indonesia). The province has a tropical humid climate $\left(27^{\circ} \mathrm{C} ; 2200 \mathrm{~mm}\right.$ yr-1; 110- $260 \mathrm{~mm}$ month-1) with a rainy season lasting from October to April. The western part of the province is a mountainous area, whose altitude exceeds $1000 \mathrm{~m}$. The majority of the province area lay on the peneplain. This undulating landscape rarely reaches a higher altitude than $200 \mathrm{~m}$ a.s.l. The landscape on the east side, from Jambi city to the sea, gradually changes from well-drained lowland to wetland areas composed of forested peatlands and mangroves. Acrisols of various textures and clay accumulation intensities are the most common soils found in the peneplain. Rubber cultivation was introduced by the Dutch at the beginning of the 20th century. Rubber trees were cultivated as agroforest (jungle rubber). An intensification of rubber cultivation started in the 70s with a large-scale extension of rubber tree monocultures. The oil palm boom started in the late 80s. Nowadays, Jambi province is the 5th biggest producer of oil palm and the 3rd for natural rubber in Indonesia.

\subsubsection{Sampling design}

Soil samples were collected using two sampling designs. (1) The sampling followed the design of the $\mathrm{C}$ group (human dimension). Villages from five lowland regencies of Jambi province were selected according to the household survey design. In collaboration with the subproject C01, 207 extensive rubber, intensive rubber or oil palm plantations were selected within the villages. In each plantation, soil samples $(0-5 \mathrm{~cm})$ were collected beside trees, within rows and in inter rows of the plantations. Additionally, $\mathrm{C} 01$ gathered information on the management and the yield of each plantation. These samples were used for the first study. (2) The sampling followed the design of the A and B group. Two regions with different soil texture were selected; the Bukit region (clay Acrisols) and the Harapan region (loam Acrisols). All A and B group subproject used the same $50 * 50 \mathrm{~m}$ plots that were established in four replicate sites of forest, jungle rubber, 
rubber and oil palm plantations in each region. Soil samples were collected by horizons in one pit per plot. These soil samples were used in all studies except the first study. Finally, the soil solution was collected at two depths $(15$ and $75 \mathrm{~cm})$ during one year in two replicate sites of each land-use type in the Harapan region.

Table 2-1. New approaches developed in the thesis

\begin{tabular}{|c|c|c|}
\hline Objective & Method & Application/Validation \\
\hline $\begin{array}{l}\text { Objective (2); } \\
\text { Study } 2 \\
\text { Quantification } \\
\text { of soil erosion }\end{array}$ & $\begin{array}{l}\text { Depth distribution of } \delta^{13} \mathrm{C} \text { values } \\
\text { Calculating depth shift (erosion) from } \delta^{13} \mathrm{C} \text { values } \\
\text { shift between forest and plantation subsoils } \\
\mathbf{1}^{\text {st }} \text { step: Estimating the parameters of an } \\
\text { exponential function describing the } \delta^{13} \mathrm{C} \text { values } \\
\text { depth distribution under forest } \\
\mathbf{2}^{\text {nd }} \text { step: calculating the original depth (according } \\
\text { to their } \delta^{13} \mathrm{C} \text { value) of samples collected under } \\
\text { plantation using parameters estimated under forest }\end{array}$ & $\begin{array}{l}\text { Applicable if the subsoil is not } \\
\text { affected by the land-use change, } \\
\text { and when the } \delta^{13} \mathrm{C} \text { values can be } \\
\text { described by a function. The } \\
\text { method can be validated by } \\
\text { applying it in a site where the } \\
\text { erosion was monitored by other } \\
\text { methods }\end{array}$ \\
\hline $\begin{array}{l}\text { Objective (2); } \\
\text { Study } 2 \\
\text { Assessing } \\
\text { changes in SOC } \\
\text { turnover }\end{array}$ & $\begin{array}{l}{ }^{13} \mathrm{C} \text { enrichment of SOC } \\
\text { There is a linear relationship between the logarithm } \\
\text { of } \mathrm{C} \text { content and the } \delta^{13} \mathrm{C} \text { value in undisturbed well- } \\
\text { drained soil. Changes in SOC turnover in } \mathrm{Ah} \\
\text { horizons are indicated by a deviation of the } \mathrm{Ah} \\
\text { horizon from the linear relationship estimated from } \\
\text { the subsoil. SOC less enriched in }{ }^{13} \mathrm{C} \text { than expected } \\
\text { from their C content indicates a decrease of } \\
\text { decomposition rate, and vice versa. }\end{array}$ & $\begin{array}{l}\text { Applicable if the subsoil is not } \\
\text { affected by the land-use change. } \\
\text { Method not validated yet. Mass } \\
\text { balance modeling showed that } \\
\text { SOC }{ }^{13} \mathrm{C} \text { enrichment depends on } \\
\text { decomposition rate (Acton et } \\
\text { al., 2013). Basal respiration } \\
\text { results were in agreement with } \\
\text { the hypothesis of lower turnover } \\
\text { under oil palm }\end{array}$ \\
\hline $\begin{array}{l}\text { Objective (5); } \\
\text { Study } 3 \\
\text { Sensitivity of } \\
\text { soil fertility } \\
\text { indicators }\end{array}$ & 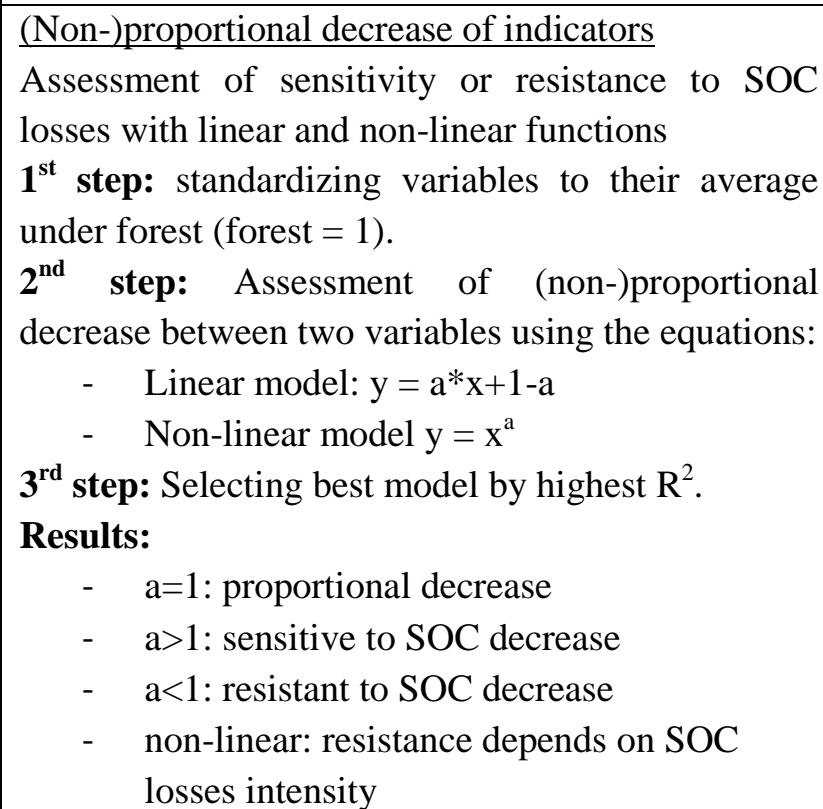 & $\begin{array}{l}\text { Fully applicable if there is a } \\
\text { gradient of land-use intensity } \\
\text { (e.g. of SOC losses). } \\
\text { Applicable for any soil } \\
\text { property, process or functions } \\
\text { that can reach zero; otherwise } \\
\text { the standardization must be } \\
\text { adapted (e.g. for C/N ratio). The } \\
3^{\text {rd }} \text { step is more efficient if soils } \\
\text { with low SOC values are } \\
\text { included. The determination of } \\
\text { (non-)linearity is fundamental to } \\
\text { determine thresholds in soil } \\
\text { functioning and to adapt land- } \\
\text { use intensity accordingly. }\end{array}$ \\
\hline
\end{tabular}




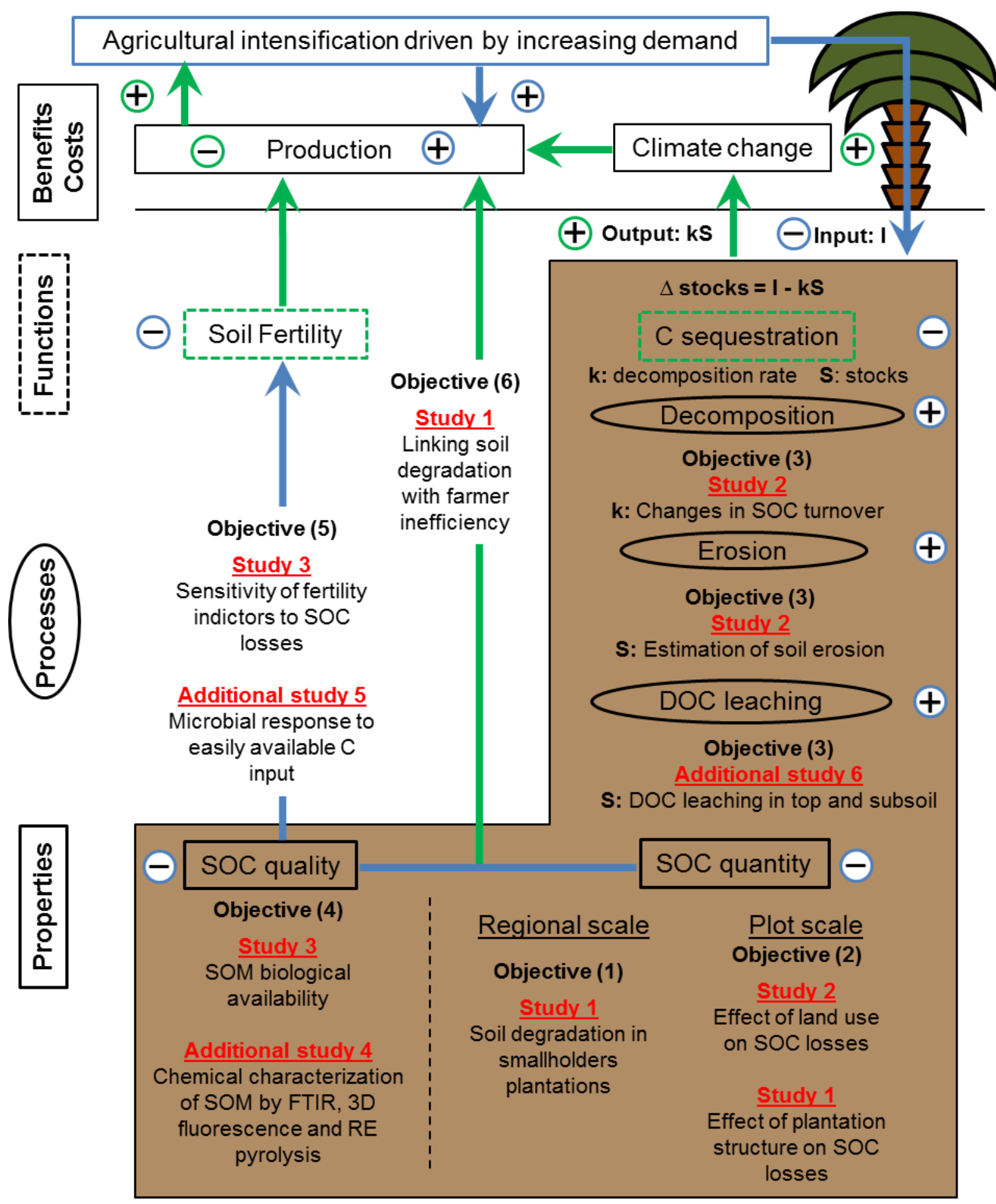

Impact of agricultural intensification on soil functions

Feedback from the soil

Figure 2-1: Schematic overview of the problematics, general objectives and aims of single studies. The figure should be entered from the box "agricultural intensification", following the blue arrows. 


\section{Publications and Manuscripts}

\subsection{Study 1}

\section{Soil degradation in oil palm and rubber plantations under land resource scarcity}

Thomas Guillaume ${ }^{1 *}$, Anna Mareike Holtkamp², Muhammad Damris ${ }^{3}$, Bernhard Brümmer ${ }^{2}$, Yakov Kuzyakov ${ }^{1}$

${ }^{1}$ Department of Soil Science of Temperate Ecosystems, and Department of Agricultural Soil Science, Georg-August-University of Göttingen, Germany

${ }^{2}$ Department of Agricultural Economics and Rural Development, Georg-August-University of Göttingen, Germany

${ }^{3}$ Faculty of Engineering, University of Jambi, Indonesia

Status: Submitted to Global Change Biology since 08.10.2015

*Corresponding Author:

Georg-August-University of Göttingen

Department of Soil Science of Temperate Ecosystems

Büsgenweg 2

37077 Göttingen, Germany

Tel. + 495513922061 Fax + 49551393310 ,

email: thoguillaume@gmail.com 


\subsubsection{Abstract:}

Tropical regions experiencing extensive transformation of natural ecosystems, such as Sumatra, are close to complete exhaustion of available land. Agroecosystems strongly modify water and nutrient cycles, leading to losses of soil fertility, $\mathrm{C}$ sequestration and biodiversity. Although large companies are the main drivers of deforestation, smallholders account for $40 \%$ of the oil palm and the majority of the rubber production in Indonesia. Here, we assess the extent and mechanisms of soil degradation under smallholder oil palm and rubber plantations in Jambi province of Sumatra, illustrating a new stage of tropical agricultural intensification that is achieved by land-use intensification rather than by conversion of natural ecosystems. The topsoil properties ( $\mathrm{C}$ and $\mathrm{N}$ contents, $\mathrm{C}$ stocks, $\mathrm{C} / \mathrm{N}$ ratio, bulk density) in 207 plantations were determined beside trees, inside rows and interrows. Soils under oil palms were on average more degraded than under rubber, showing lower $\mathrm{C}$ content and stocks, lower $\mathrm{N}$ and higher bulk density. While soil properties were homogenous under rubber, two opposite trends were observed under oil palm plantations: the majority of soils had $<2.2 \% \mathrm{C}$, but about one fifth of the plantations had $>9 \% \mathrm{C}$. This resulted from the establishment of oil palms under conditions of land scarcity. Because the oil palm boom started when rubber was already well-established, oil palms were frequently planted in marginal areas, such as peatlands or riparian areas (high C) or soils degraded by previous use (low $\mathrm{C}$ ). The management of oil palms led to subsequent soil degradation, especially in interrows. Considering that $10 \%$ of soils under oil palms have $<1 \% \mathrm{C}$, intensive plantations will experience further soil degradation. This challenges the sustainability of tropical agricultural intensification. Because Sumatra is a pioneer of tropical land-use change, this should be regarded as a threat that other tropical regions will face in future. 


\subsubsection{Introduction}

Agricultural intensification in response to an increasing demand for food, feed, timber and biofuel has led to extensive conversion of natural ecosystems to agroecosystems (Tilman et al., 2001; Lambin \& Meyfroidt, 2011). In tropical regions, new agricultural lands were gained mostly at the expense of forested land (Gibbs et al., 2010), resulting in a strong decrease of tropical forest area worldwide (Hansen et al., 2013). In 2012, Indonesia became the main deforestation hotspot, with a higher rate than Brazil (Margono et al., 2014). However, the loss of forests is not a new trend in Indonesia. Sumatra Island had already lost almost half of its forest cover by 1985 (Laumonier et al., 2010). Out of the three biggest Indonesian islands (Sumatra, Kalimantan and Papua), Sumatra is the one where deforestation is most advanced, with only $9 \%$ of lowland forest cover left in 2012 (Margono et al., 2014). Because most of the easily accessible forest on Sumatra had already been transformed before 2000, new agricultural land was mainly established in marginal areas, such as wetlands or hilly landscapes (Miettinen et al., 2012a; Margono et al., 2014). The exhaustion of easily accessible forest on Sumatra is also indicated by forested area under new industrial concession five times lower compared to Kalimantan, or Papua where deforestation is at a nascent stage (Abood et al., 2015). The main drivers of deforestation in Indonesia are the pulp, timber, mining, rubber and oil palm industries (Abood et al., 2015). While extensive rubber cultivation started at the beginning of the 20th century (Feintrenie et al., 2010), the oil palm boom started only in the late 1980s with an increase from 1 million ha in 1990 to 7.1 million ha in 2013 (FAOSTAT).

Smallholder farmers play an important and increasing role in oil palm production, already accounting for $40 \%$ of total Indonesian production (Euler et al., 2015a). While rubber and oil palm cultivation has a positive impact on smallholder farmers' livelihoods (Euler et al., 2015b), they are associated with extensive ecosystem degradation (Wilcove \& Koh, 2010; Barnes et al., 2014). A reduced net primary production (Kotowska et al., 2015), very high soil erosion (Guillaume et al., 2015), the use of fertilizers (Allen et al., 2015) and soil compaction are threats to soil fertility. In fact, various studies have reported a strong decrease of soil organic carbon (SOC) after conversion to plantations, with most of the losses from the topsoil (de Blécourt et al., 2013; Guillaume et al., 2015; van Straaten et al., 2015). Aside from its role in C sequestration, SOC is an important indicator of soil fertility in the heavily-weathered soils common in the tropics. Because of nutrient leaching in the tropics, nutrient recycling between the vegetation and 
the organic matter in the topsoil is the main source of nutrients to sustain plant growth (Vitousek, 1984). An large decrease of SOC under rubber and oil palm plantations would, therefore, raise major concerns about the sustainability of such land-use types in the tropics (Lal, 2010).

Sumatra Island is a pioneer region for tropical land-use changes. Therefore, it is a relevant model to assess the impacts of agricultural intensification on soil degradation in the tropics since these will be observed on Sumatra before other locations. Consequently, the experiences from this region could be of relevance for tropical regions, such as Kalimantan, Papua or Central Africa in order to mitigate the environmental cost of tropical forest conversion to agroecosystems. The objectives of this study were 1) to assess the soil quality under smallholders' rubber and oil palm plantations in the Jambi province, a province in Sumatra with one of the most advanced transformation of natural ecosystems, 2) to assess differences in the degradation of soils between plantation types and 3) to assess the soil heterogeneity within plantations resulting from smallscale management practices. 


\subsubsection{Materials and Methods}

\section{Study area}

The study was conducted in the lowland (peneplain) of Jambi province, located in central Sumatra, Indonesia. The entire region has a tropical humid climate $\left(27^{\circ} \mathrm{C} ; 2200 \mathrm{~mm} \mathrm{yr}-1 ; 110-\right.$ $260 \mathrm{~mm}$ month-1) with a rainy season lasting from October to April. Acrisols are the dominant soil type in the lowland of Jambi province, but peats (Histosols) are frequent in landscape depressions and in the vicinity of the east coast (Ishizuka et al., 2005; Hooijer et al., 2010). Jambi province is the 5th largest producer of oil palm and the 3rd largest for rubber in Indonesia (Schwarze et al., 2015). Oil palm cultivation by smallholders in Jambi Province started in the late 1980s, when rubber was already a well-established cash crop, occupying 510,000 ha in 1996 (Gatto et al., 2015). While the area under rubber increased by 27\% from 1996 to 2011, the area under oil palm almost quadrupled during that time, reaching 580,000 ha. During the 1980s and 1990s, the Indonesian government favored the establishment of oil palms by smallholder farmers through various so-called "transmigration programs" and collaboration with private companies (McCarthy \& Cramb, 2009). Nowadays, however, smallholder adoption mainly occurs independently. While the area under oil palm is still increasing, the adoption rate by farmers reached a peak in 2007 and has declined since then (Euler et al., 2015a). Oil palm cultivation is not spread evenly across the province (Fig. 3-1). Because the harvested fresh fruit bunches have to be processed within 1-2 days to maintain good product quality, the cultivation of oil palm is constrained by the location of the palm oil mills and the quality of infrastructure such as roads. The regency of Muaro Jambi, the closest to the province's capital, has the largest area under oil palm and the largest number of mills (Euler et al., 2015). 


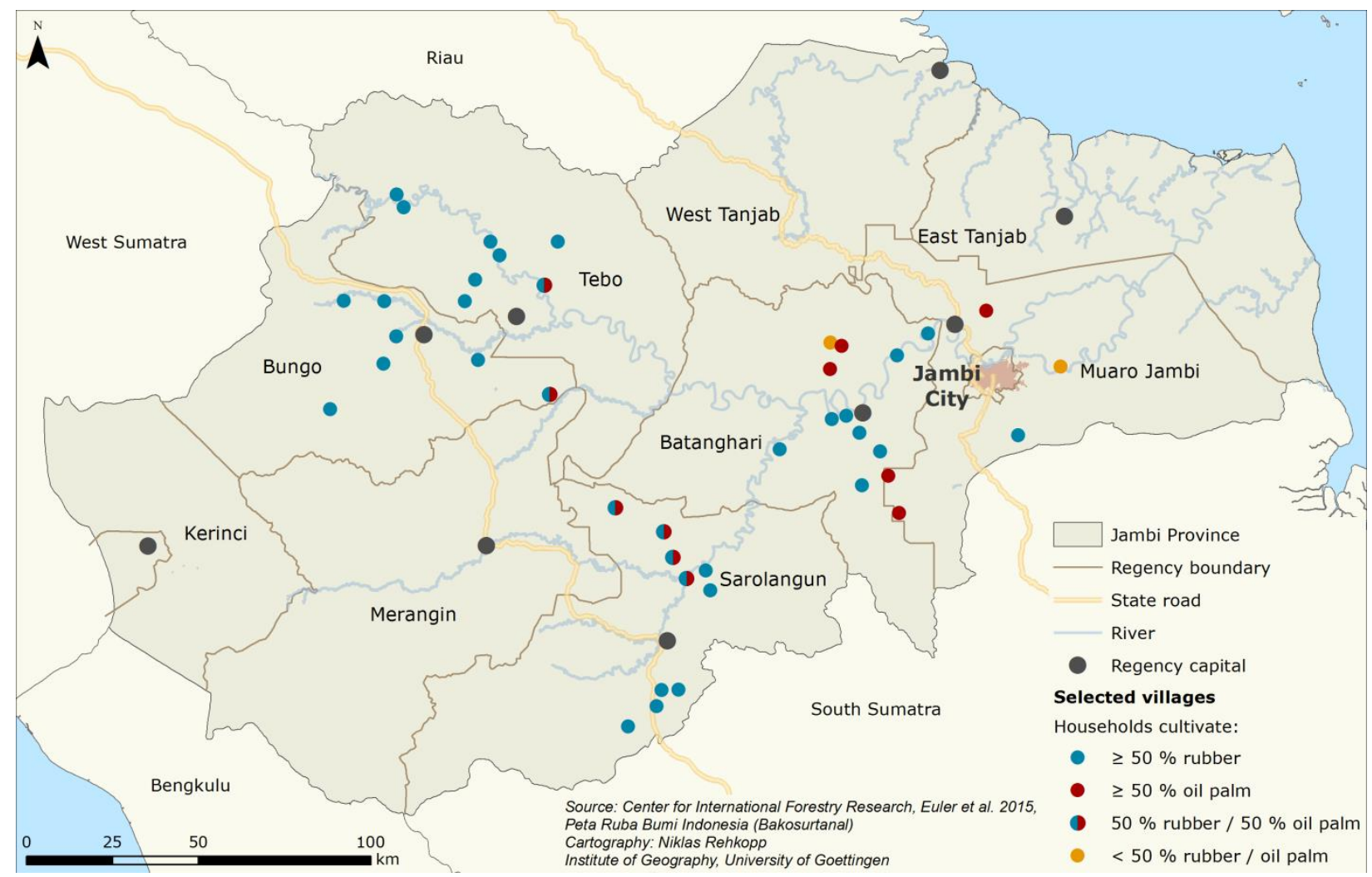

Figure 3-1: Map of the Jambi province with the proportion of rubber and oil palm adoption by farmers in the selected villages.

Map is reproduced from Faust et al. (2013). Adoption data from household survey conducted by (Euler et al., 2015a).

\section{Plantation selection}

Five major lowland regencies (Bungo, Batanghari, Muaro Jambi, Sarolangun and Tebo) covering half of the 53,000 km2 of the Province were purposely selected, because they include most of the smallholder oil palm producers in the province (Euler et al., 2015a). To capture the plantation diversity of the province, a random sampling approach was used to select four districts per regency and two villages per district, for a total of 40 villages (Faust et al., 2013). In each village, one third of the farmers were selected randomly for a total of 207 plantations sampled, including 16 extensive rubber, 146 intensive rubber and 45 oil palm plantations (Table 3-1). The lower number of sampled oil palm compared to sampled rubber plantations $(30 \%)$ corresponded to the difference in the surface area allotted to each plantation type (36\%), as observed in a larger survey of 100 villages of the Jambi Province (Schwarze et al., 2015). 82\% of the sampled oil palm plantations were located in the regencies of Batanghari and Muaro Jambi. This reflected the 
high oil palm adoption rates observed in these two regencies (Euler et al., 2015a). The oil palm plantations of Sarolangun, however, might have been slightly under-represented, because the oil palm adoption rate was found to be intermediate between those in Muaro Jambi and Batanghari.

\section{Plantation characteristics}

All plantations were smallholder plantations. According to a larger survey, the average area cultivated per farm was 3.6 ha for oil palm and 2.9 ha for rubber (Schwarze et al., 2015). With an average age of 11 years, oil palm plantations were younger than rubber plantations (17 years). Management was more intense in oil palm plantations. Fertilizers and herbicide were applied in 78 and $81 \%$, respectively, of the oil palm plantations, while they were used in only 28 and $49 \%$ of the rubber plantations. Moreover, when used, farmers invest three times more for application of fertilizers and herbicides per ha of oil palm than per ha of rubber (Schwarze et al., 2015). The amount of labor per ha is lower for oil palm than for rubber plantations (which are commonly tapped every two days), but the labor requirements are much less evenly distributed over time, and peak at the harvesting dates, usually twice a month. Generally, dead oil palm fronds are collected and piled every 2 to 3 interrows, and residues from oil palm bunches or fruit are not spread on the plantations.

\section{Soil sampling and analysis}

Soil samples were collected in representative areas away from the edges of the plantations, i.e. roads, harvesting paths, etc. were avoided. To assess the effects of the structure of oil palm plantations on the soil, samples were collected in four operational zones of each plantation (Fig. 3-2): beside a tree (within $30 \mathrm{~cm}$ ); directly between two trees of the same row (the maximum distance from tree effects inside a row); in the interrow between two trees; and at the midpoint between four trees (the maximum distance from tree effects in the interrow). Because of the absence of structure in extensive rubber plantations, and to keep the same sampling design, samples from extensive rubber plantations were collected at each corner of a 5-by-5 meter square, where one corner was located at the base of a rubber tree. Soil samples were collected with a $3.8 \mathrm{~cm}$ diameter ring from 0 to $5 \mathrm{~cm}$ depth, because most of the $\mathrm{C}$ losses are located in the topsoil (Guillaume et al., 2015). The collected soil was air-dried, sieved at $2 \mathrm{~mm}$ to remove 
coarse-root residues, oven-dried at $105{ }^{\circ} \mathrm{C}$ and weighed to calculate bulk density. Carbon and $\mathrm{N}$ contents of ground soil were measured at the Georg-August University of Göttingen using an elemental analyser (Eurovector).

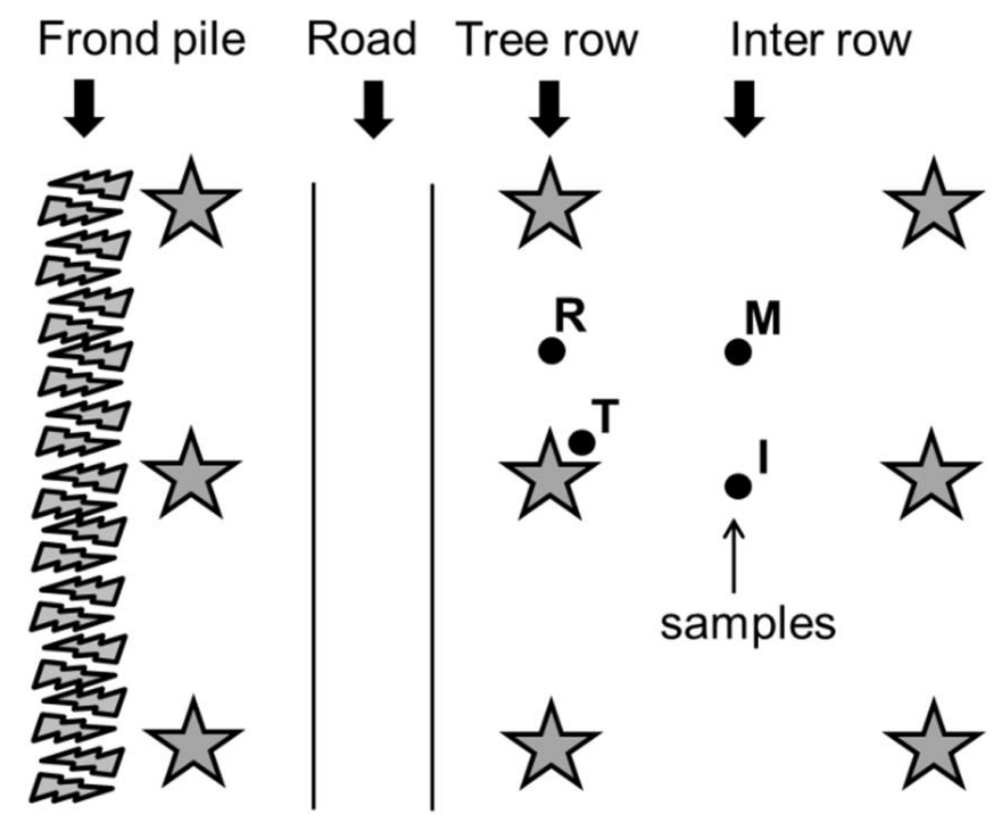

Figure 3-2: Soil sampling design of study 1

In oil palm plantations, frond piles, roads and other disturbed locations were avoided to ensure sampling representativeness. In each rubber and oil palm plantation, samples were collected close trees (T), in the rows between two trees (R), in the interrows between two trees (I) or at the midpoint between four trees (M). This sampling design allowed investigation of the small scale spatial distribution of soil properties within the plantations.

\section{Statistics}

All statistical analyses were performed using the open source software $\mathrm{R}$ version 3.2.2. Differences in the $\mathrm{C}$ and $\mathrm{N}$ contents and $\mathrm{C}$ stocks, $\mathrm{C} / \mathrm{N}$ ratio and bulk density of mineral soils $(<$ $14 \%$ ) between plantation types or between regencies were tested by the Kruskal-Wallis test because of unequal samples sizes and non-normal distributions. Due to missing values for bulk density, three rubber and four oil palm plantations were not included when testing bulk density and stocks. The difference in soil properties between plantation types (the median of all possible differences between a sample from one plantation type and a sample from a second plantation type) and their confidence intervals were estimated by Mann-Whitney $U$ tests (function wilcox.test in R). Kolmogorov-Smirnov tests (function Ks.test in R) were used to assess the similarity of the soil properties under rubber and oil palm plantations of Muaro Jambi. The 
heterogeneity of soil properties ( $\mathrm{C}$ and $\mathrm{N}$ content, $\mathrm{C}$ stocks, $\mathrm{C} / \mathrm{N}$ ratio and bulk density) within each plantation was tested separately for each plantation type by a linear mixed effects model (function lme in R) including the four operational zones as fixed factors and the plantation as a random effect. Except for bulk density, all values were log-transformed to reach variance homogeneity and normality for residuals and for the random effect. Five plantations under intensive rubber and one under extensive rubber, having extreme values in one or more locations of one or more soil properties, were not included. Seven oil palm plantations with high variability of one or more soil properties were analyzed separately. Because of non-normal distributions, medians instead of means were used. If not specified, discussed differences are significant at least at a p-value $<0.05$. 


\subsubsection{Results}

\section{Soil characteristics under plantations}

The 828 soil samples covered the full range of $\mathrm{C}$ content in soil: from purely mineral $(<0.1 \% \mathrm{C})$ to purely organic (60\% C) soils (Fig. 3-3). The lowest mean C content of a plantation, however, was $0.59 \%$ in the top $5 \mathrm{~cm}$ of the soil. Despite the fact that the plantations were located mostly on mineral soil with low C content (median: 3.7\%, Table 3-1), organic soils, as defined by the World Reference Base ( $\geq 20 \% \mathrm{C}$ ), were found under five out of the 45 oil palm plantations and three out of 146 rubber plantations.

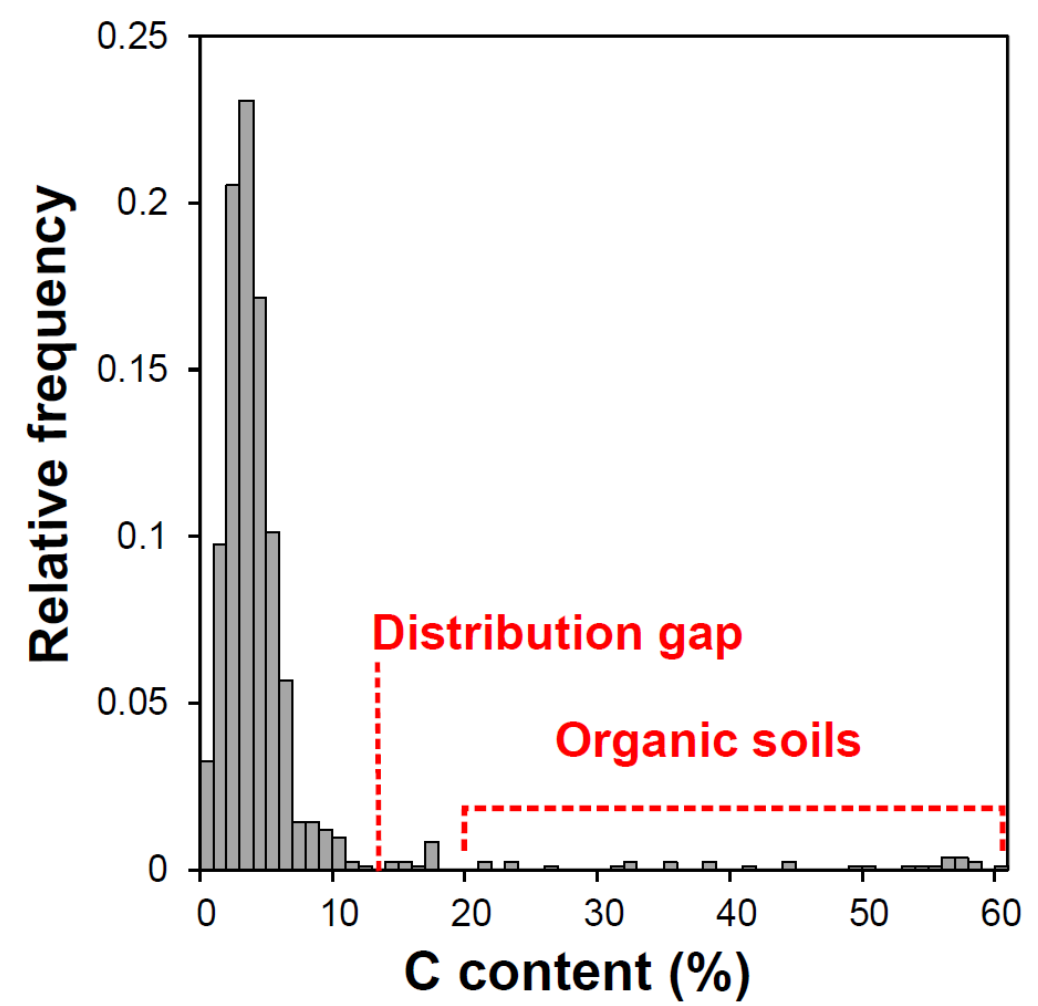

Figure 3-3: C content distribution of the 207 plantations.

The soils above $20 \%$ C content were considered as organic soils (IUSS Working Group WRB, 2014). Because of a distribution gap between 13 and $14 \% \mathrm{C}$ content, the soils above this threshold were not included when comparing land-use types. Soils above $14 \% \mathrm{C}$ content were found only under intensive rubber (3\% of soils) and oil palm (13\% of soils).

The distribution of $\mathrm{C}$ content in mineral soils had a gap with a distinct group of 12 mineral soil samples from two oil palm and five rubber plantations having a high $\mathrm{C}$ content (from 14 to $18 \%$ ). The maximum $\mathrm{C}$ content did not exceed $6.3 \%$ under extensive rubber plantations. The distribution of $\mathrm{C}$ content in mineral soils $(<14 \% \mathrm{C})$ was different between plantation types. The 
C content and bulk density were normally distributed among extensive rubber plantations (Fig. 3-4) with similar median $\left(3.5 \% \mathrm{C} ; 0.89 \mathrm{~g} \mathrm{~cm}^{-3}\right)$ and mean (Table 3-1). Intensive and extensive rubber plantations did not differ in their $\mathrm{C}$ and $\mathrm{N}$ contents, but intensive rubber plantations had higher bulk densities, resulting in higher $\mathrm{C}$ stocks in the top $5 \mathrm{~cm}$ of soils (Table 3-1). Furthermore, soils under intensive rubber showed a larger variation in $\mathrm{C}$ content and bulk density distributions. The $\mathrm{C}$ content was not normally distributed; values were slightly skewed to low $\mathrm{C}$ content with a median $(3.7 \% \mathrm{C})$ lower than the mean $(4.0 \% \mathrm{C})$. The variability and the skewness of the $\mathrm{C}$ content and bulk density distribution were much stronger under oil palm (Fig. $3-4)$. Soils having either low $\mathrm{C}$ content $(<2 \% \mathrm{C})$ and high bulk density $\left(>1.2 \mathrm{~g} \mathrm{~cm}^{-3}\right.$ ) or high $\mathrm{C}$ content (> 9\% C) and low bulk density $\left(<0.8 \mathrm{~g} \mathrm{~cm}^{-3}\right)$ were much more frequent under oil palm than under rubber plantations. Consequently, the $\mathrm{C}$ content under oil palms was significantly lower than under intensive

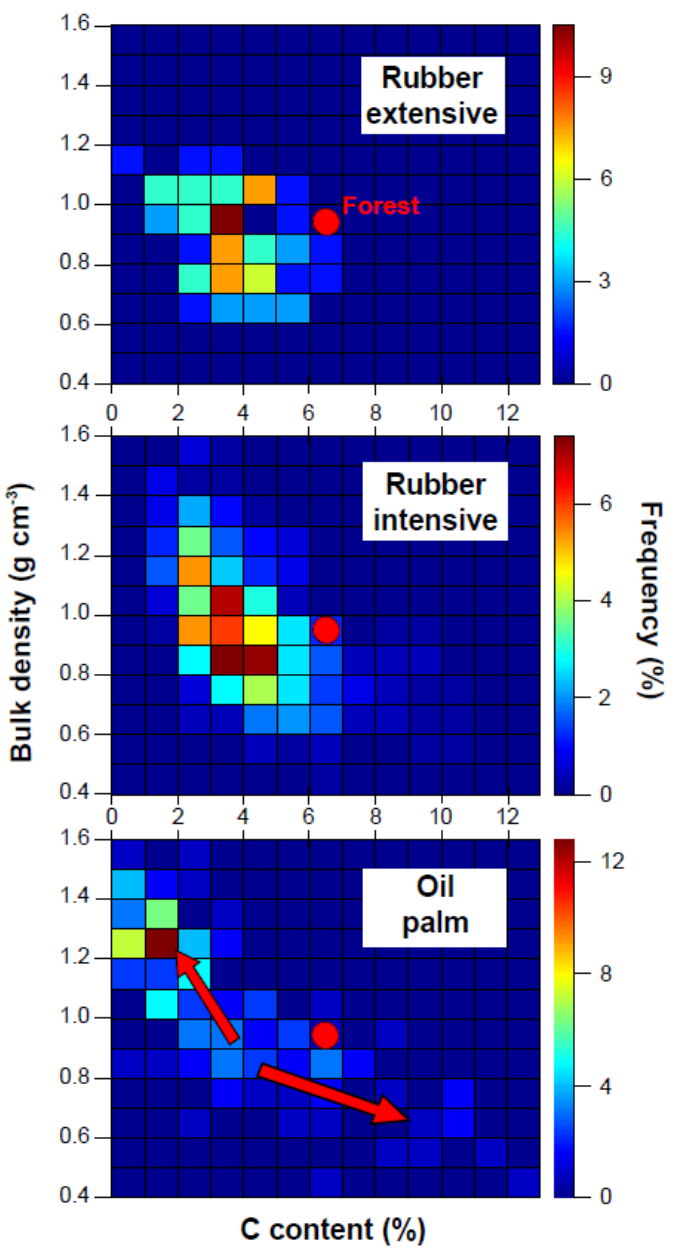

Figure 3-4: Distributions of $\mathrm{C}$ content and bulk density in mineral soils under three landuse types: extensive and intensive rubber, and oil palm plantations.

rubber (-1.3\%; CI: $-1.6,-1 \%)$ and under extensive rubber (-1.1\%; CI: $-1.5,-0.6)$; only $10 \%$ of the intensive rubber plantations had a lower $\mathrm{C}$ content than the median $\mathrm{C}$ content under oil palm. Oil palm also had lower $\mathrm{N}$ content and $\mathrm{C}$ stocks, but higher bulk density compared to rubber plantations (Table 3-1).

Intensive rubber plantations were distributed fairly uniformly across the five regencies (Table 31). The strongest differences between median soil parameters of the regencies did not exceed $0.9 \% \mathrm{C}$ content, $0.05 \% \mathrm{~N}$ content and $0.11 \mathrm{~g} \mathrm{~cm}^{-3}$, indicating limited variability in $\mathrm{C}, \mathrm{N}$ and bulk density under intensive rubber plantations between regencies (Table 3-1). $82 \%$ of oil palm plantations were located in two regencies: Muaro Jambi (23 plantations) and Batanghari (14 plantations). 
Table 3-1. Soil properties under extensive rubber (ER), intensive rubber (IR) and oil palm (OP) plantations in Jambi province and in its regencies.

\begin{tabular}{|c|c|c|c|c|c|c|c|c|}
\hline \multirow[t]{2}{*}{$\begin{array}{l}\text { Province/ } \\
\text { Regency }\end{array}$} & \multirow[t]{2}{*}{$\begin{array}{c}\text { Land } \\
\text { use }\end{array}$} & \multicolumn{2}{|c|}{ plantations ${ }^{1}$} & \multirow{2}{*}{$\begin{array}{l}\mathrm{C} \\
\%\end{array}$} & \multirow{2}{*}{$\begin{array}{l}\mathrm{N} \\
\%\end{array}$} & \multirow[t]{2}{*}{$\mathrm{CN}$} & \multirow{2}{*}{$\begin{array}{l}\text { Bulk density } \\
\qquad \mathrm{g} \mathrm{cm}^{-3}\end{array}$} & \multirow{2}{*}{$\begin{array}{c}\text { SOC stocks } \\
\mathrm{kg} \mathrm{m}^{-2}\end{array}$} \\
\hline & & MS & OS & & & & & \\
\hline \multirow{3}{*}{$\begin{array}{l}\text { Jambi } \\
\text { province } \\
(656 ; 55)^{3}\end{array}$} & ER & 16 & - & $\begin{array}{c}3.5^{4} \mathrm{~b}^{5} \\
(3.6 ; 1.2)\end{array}$ & $\begin{array}{c}0.27 \mathrm{~b} \\
(0.29 ; 0.10)\end{array}$ & $\begin{array}{c}12.1 \mathrm{a} \\
(12.4 ; 2.3)\end{array}$ & $\begin{array}{c}0.89 \mathrm{a} \\
(0.89 ; 0.15)\end{array}$ & $\begin{array}{c}1.5 \mathrm{a} \\
(1.6 ; 0.5)\end{array}$ \\
\hline & IR & 139 & 7 & $\begin{array}{c}3.7 \mathrm{~b} \\
(4.0 ; 1.6)\end{array}$ & $\begin{array}{c}0.29 \mathrm{~b} \\
(0.31 ; 0.12)\end{array}$ & $\begin{array}{c}12.6 \mathrm{a} \\
(13.0 ; 2.5)\end{array}$ & $\begin{array}{c}0.95 \mathrm{~b} \\
(0.97 ; 0.21)\end{array}$ & $\begin{array}{c}1.8 \mathrm{~b} \\
(1.9 ; 0.6)\end{array}$ \\
\hline & OP & 38 & 7 & $\begin{array}{c}2.2 \mathrm{a} \\
(3.1 ; 2.6) \\
\end{array}$ & $\begin{array}{c}0.16 \mathrm{a} \\
(0.23 ; 0.17)\end{array}$ & $\begin{array}{c}12.7 \mathrm{a} \\
(13.3 ; 3.4) \\
\end{array}$ & $\begin{array}{c}1.10 \mathrm{c} \\
(1.07 ; 0.25)\end{array}$ & $\begin{array}{c}1.3 \mathrm{a} \\
(1.5 ; 0.9) \\
\end{array}$ \\
\hline \multirow[t]{3}{*}{$\begin{array}{l}\text { Sarolangun } \\
(141 ; 10)\end{array}$} & ER & 3 & - & $\begin{array}{c}3.0 \\
(3.2 ; 1.1)\end{array}$ & $\begin{array}{c}0.27 \\
(0.29 ; 0.10)\end{array}$ & $\begin{array}{c}10.8 \\
(10.9 ; 0.8)\end{array}$ & $\begin{array}{c}0.88 \\
(0.87 ; 0.16)\end{array}$ & $\begin{array}{c}1.3 \\
(1.3 ; 0.3)\end{array}$ \\
\hline & IR & 36 & 3 & $\begin{array}{c}3.3 \mathrm{~A} \\
(3.8 ; 1.9)\end{array}$ & $\begin{array}{c}0.27 \mathrm{AB} \\
(0.30 ; 0.12)\end{array}$ & $\begin{array}{c}12.1 \mathrm{~A} \\
(12.8 ; 3.0)\end{array}$ & $\begin{array}{c}0.93 \mathrm{AB} \\
(0.93 ; 0.23)\end{array}$ & $\begin{array}{c}1.6 \mathrm{~A} \\
(1.7 ; 0.7)\end{array}$ \\
\hline & OP & 3 & 1 & $\begin{array}{c}3.8 \\
(3.6 ; 1.6)\end{array}$ & $\begin{array}{c}0.27 \\
(0.27 ; 0.12)\end{array}$ & $\begin{array}{c}12.7 \\
(13.2 ; 1.7)\end{array}$ & $\begin{array}{c}1.07 \\
(1.02 ; 0.19)\end{array}$ & $\begin{array}{c}1.7 \\
(1.7 ; 0.7)\end{array}$ \\
\hline \multirow[t]{3}{*}{$\begin{array}{l}\text { Batanghari } \\
(113 ; 8)\end{array}$} & ER & 4 & - & $\begin{array}{c}3.2 \\
(2.9 ; 1.1)\end{array}$ & $\begin{array}{c}0.23 \\
(0.21 ; 0.07)\end{array}$ & $\begin{array}{c}13.3 \\
(12.6 ; 3.2)\end{array}$ & $\begin{array}{c}0.89 \\
(0.88 ; 0.15)\end{array}$ & $\begin{array}{c}1.2 \\
(1.2 ; 0.4)\end{array}$ \\
\hline & IR & 27 & - & $\begin{array}{l}3.6 \mathrm{~b}, \mathrm{AB} \\
(3.8 ; 1.3)\end{array}$ & $\begin{array}{c}0.28 \mathrm{~b}, \mathrm{AB} \\
(0.30 ; 0.12)\end{array}$ & $\begin{array}{l}12.5 \mathrm{a}, \mathrm{AB} \\
(12.7 ; 1.8)\end{array}$ & $\begin{array}{c}0.98 \mathrm{a}, \mathrm{AB} \\
(0.97 ; 0.19)\end{array}$ & $\begin{array}{l}1.7 \mathrm{~b}, \mathrm{AB} \\
(1.7 ; 0.4)\end{array}$ \\
\hline & OP & 14 & - & $\begin{array}{c}1.1 \mathrm{a} \\
(1.5 ; 1.4)\end{array}$ & $\begin{array}{c}0.09 \mathrm{a} \\
(0.11 ; 0.06) \\
\end{array}$ & $\begin{array}{c}12.3 \mathrm{a} \\
(13.3 ; 4.9)\end{array}$ & $\begin{array}{c}1.23 \mathrm{~b} \\
(1.19 ; 0.20)\end{array}$ & $\begin{array}{c}0.7 \mathrm{a} \\
(0.8 ; 0.6) \\
\end{array}$ \\
\hline \multirow{3}{*}{$\begin{array}{l}\text { Muaro } \\
\text { Jambi } \\
(151 ; 8)\end{array}$} & ER & - & - & - & - & - & - & - \\
\hline & IR & 12 & 3 & $\begin{array}{l}3.2 \mathrm{a}, \mathrm{AB} \\
(3.6 ; 1.4)\end{array}$ & $\begin{array}{c}0.27 \mathrm{a}, \mathrm{A} \\
(0.27 ; 0.08)\end{array}$ & $\begin{array}{c}13.4 \mathrm{a}, \mathrm{B} \\
(13.6 ; 3.4)\end{array}$ & $\begin{array}{c}0.99 \mathrm{a}, \mathrm{B} \\
(1.01 ; 0.18)\end{array}$ & $\begin{array}{l}1.7 \mathrm{a}, \mathrm{AC} \\
(1.8 ; 0.7)\end{array}$ \\
\hline & OP & 17 & 6 & $\begin{array}{c}3.3 \mathrm{a} \\
(4.5 ; 3.0) \\
\end{array}$ & $\begin{array}{c}0.32 \mathrm{a} \\
(0.33 ; 0.19) \\
\end{array}$ & $\begin{array}{c}13.2 \mathrm{a} \\
(13.3 ; 2.4)\end{array}$ & $\begin{array}{c}0.97 \mathrm{a} \\
(0.99 ; 0.26) \\
\end{array}$ & $\begin{array}{c}1.7 \mathrm{a} \\
(1.9 ; 0.7) \\
\end{array}$ \\
\hline \multirow[t]{3}{*}{$\begin{array}{l}\text { Tebo } \\
(105 ; 12)\end{array}$} & $\overline{\text { ER }}$ & 1 & - & $\begin{array}{c}5.0 \\
(5.1 ; 0.4)\end{array}$ & $\begin{array}{c}0.39 \\
(0.38 ; 0.08)\end{array}$ & $\begin{array}{c}12.2 \\
(13.7 ; 3.2)\end{array}$ & $\begin{array}{c}0.83 \\
(0.83 ; 0.11)\end{array}$ & $\begin{array}{c}2.0 \\
(2.1 ; 0.3)\end{array}$ \\
\hline & IR & 41 & 1 & $\begin{array}{c}4.0 \mathrm{BC} \\
(4.2 ; 1.7)\end{array}$ & $\begin{array}{c}0.32 \mathrm{BC} \\
(0.32 ; 0.12)\end{array}$ & $\begin{array}{c}12.9 \mathrm{~B} \\
(13.2 ; 2.2)\end{array}$ & $\begin{array}{c}0.97 \mathrm{~B} \\
(1.01 ; 0.20)\end{array}$ & $\begin{array}{c}1.9 \mathrm{C} \\
(2.0 ; 0.6)\end{array}$ \\
\hline & OP & 1 & - & $\begin{array}{c}2.2 \\
(2.3 ; 0.5)\end{array}$ & $\begin{array}{c}0.20 \\
(0.21 ; 0.04)\end{array}$ & $\begin{array}{c}11.2 \\
(11.1 ; 0.3)\end{array}$ & - & - \\
\hline \multirow[t]{3}{*}{$\begin{array}{l}\text { Bungo } \\
(146 ; 17)\end{array}$} & ER & 8 & - & $\begin{array}{c}4.0 \\
(3.9 ; 1.1)\end{array}$ & $\begin{array}{c}0.30 \\
(0.31 ; 0.09)\end{array}$ & $\begin{array}{c}12.4 \\
(12.7 ; 1.8)\end{array}$ & $\begin{array}{c}0.97 \\
(0.92 ; 0.15)\end{array}$ & $\begin{array}{c}1.8 \\
(1.8 ; 0.5)\end{array}$ \\
\hline & IR & 23 & - & $\begin{array}{c}4.1 \mathrm{C} \\
(4.4 ; 1.5)\end{array}$ & $\begin{array}{c}0.32 \mathrm{C} \\
(0.35 ; 0.12)\end{array}$ & $\begin{array}{c}12.7 \mathrm{~B} \\
(12.8 ; 2.1)\end{array}$ & $\begin{array}{c}0.88 \mathrm{~A} \\
(0.90 ; 0.22)\end{array}$ & $\begin{array}{c}1.8 \mathrm{BC} \\
(1.9 ; 0.6)\end{array}$ \\
\hline & OP & 3 & - & $\begin{array}{c}2.2 \\
(2.6 ; 0.9)\end{array}$ & $\begin{array}{c}0.16 \\
(0.19 ; 0.07) \\
\end{array}$ & $\begin{array}{c}13.7 \\
(13.5 ; 0.8)\end{array}$ & $\begin{array}{c}1.17 \\
(1.07 ; 0.21)\end{array}$ & $\begin{array}{c}1.3 \\
(1.3 ; 0.2)\end{array}$ \\
\hline
\end{tabular}

1 Number of plantations on mineral soils (MS; < 14\% C) and organic soils (OS > 14\% C) 2 Stocks from $0-5 \mathrm{~cm} 3$ Total number of villages and districts in the province or regencies (Source: Badan Pusat Statistik, Jakarta) 4 Median (mean; standard deviation) 5 lower case letters indicate significant differences $(\mathrm{p}<0.05)$ between land-use types (Kriskal-Wallis test) or between oil palm and intensive rubber in Batanghari and Muaro Jambi (Mann-Whitney U tests). Upper case letters indicate significant differences in soil properties between regencies (Kriskal-Wallis test)

Although the soil properties under rubber plantations in the regencies of Batanghari and Muaro Jambi were homogenous, the soils under oil palm plantations in Batanghari showed on average lower $\mathrm{C}$ content $(-2.2 \% \mathrm{C})$ and stocks $\left(-1.0 \mathrm{~kg} \mathrm{C} \mathrm{m}^{-2}\right)$, and higher bulk density $\left(+0.26 \mathrm{~g} \mathrm{~cm}^{-3}\right)$ compared to Muaro Jambi (Fig. 3-5). The median soil properties were similar in both plantation 
types in Muaro Jambi. However, this was not because the soils were similar, but rather because of the presence under oil palms of either degraded soils or soils with high $\mathrm{C}$ contents and low bulk densities. In contrast, soils with high $\mathrm{C}$ contents were rare under the oil palm plantations in Batanghari, and the degraded soils had even lower $\mathrm{C}$ contents and higher bulk densities than in Muaro Jambi, indicating great variability of soil conditions under oil palms at the regency level.

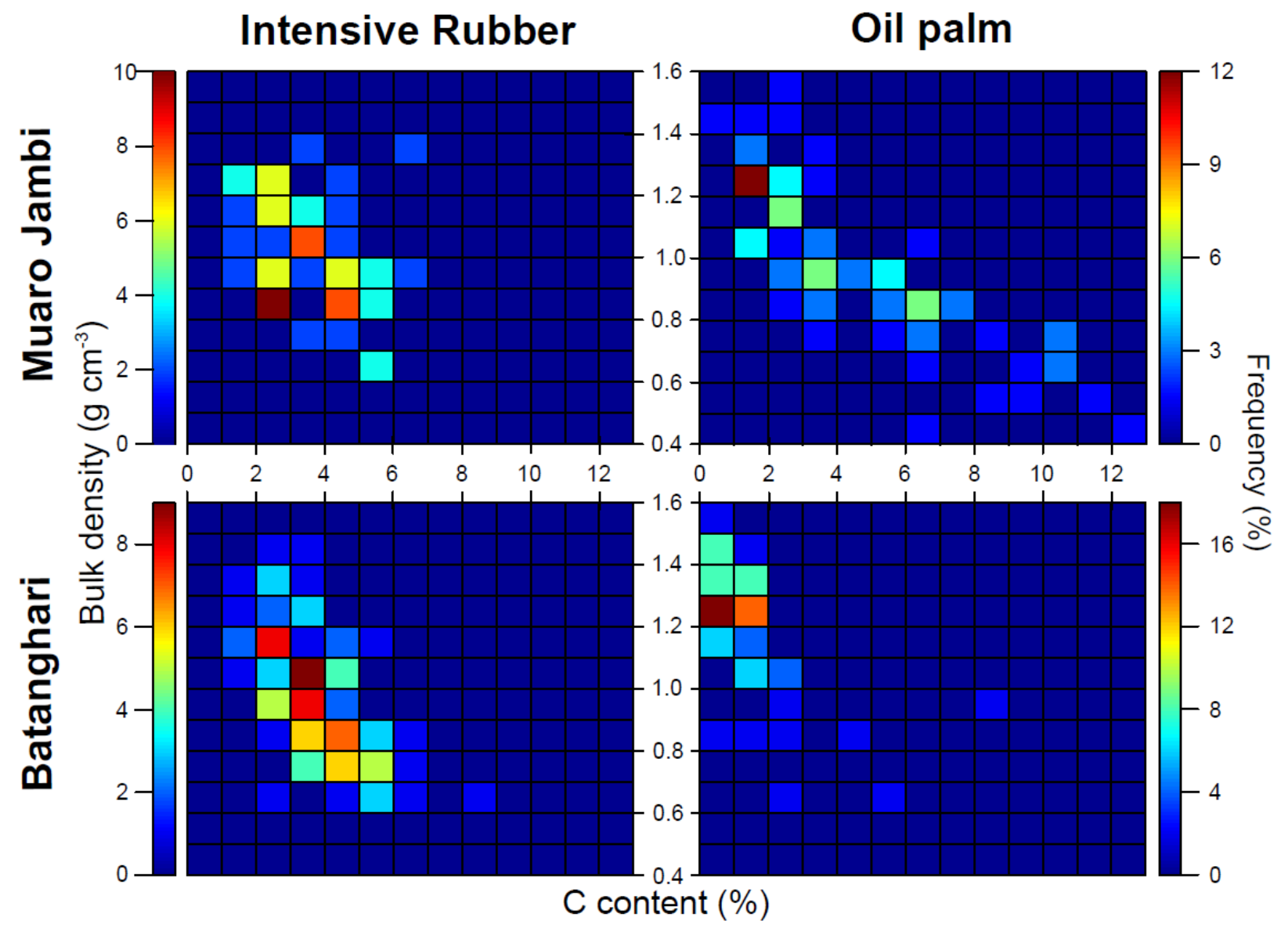

Figure 3-5: Distributions of $\mathrm{C}$ content and bulk density in mineral soils under intensive rubber and oil palm plantations in regencies of Muaro Jambi and Batanghari.

In summary, soils under extensive and intensive rubber plantations were similar and did not differ strongly between the regencies of Jambi province. The main differences consisted in wider distributions of soil properties under intensive rubber plantations. Further, higher bulk density resulted in higher $\mathrm{C}$ stocks in the upper $5 \mathrm{~cm}$ under intensive compared to extensive plantations. In contrast, soils under oil palm plantations were more heterogeneous with a higher frequency of soils with either low or high $\mathrm{C}$ content and bulk density. In conclusion, soils under oil palm 
plantations were on average more degraded (lower C content and stocks, and higher bulk density) than under rubber plantations.

\section{Spatial heterogeneity within plantations}

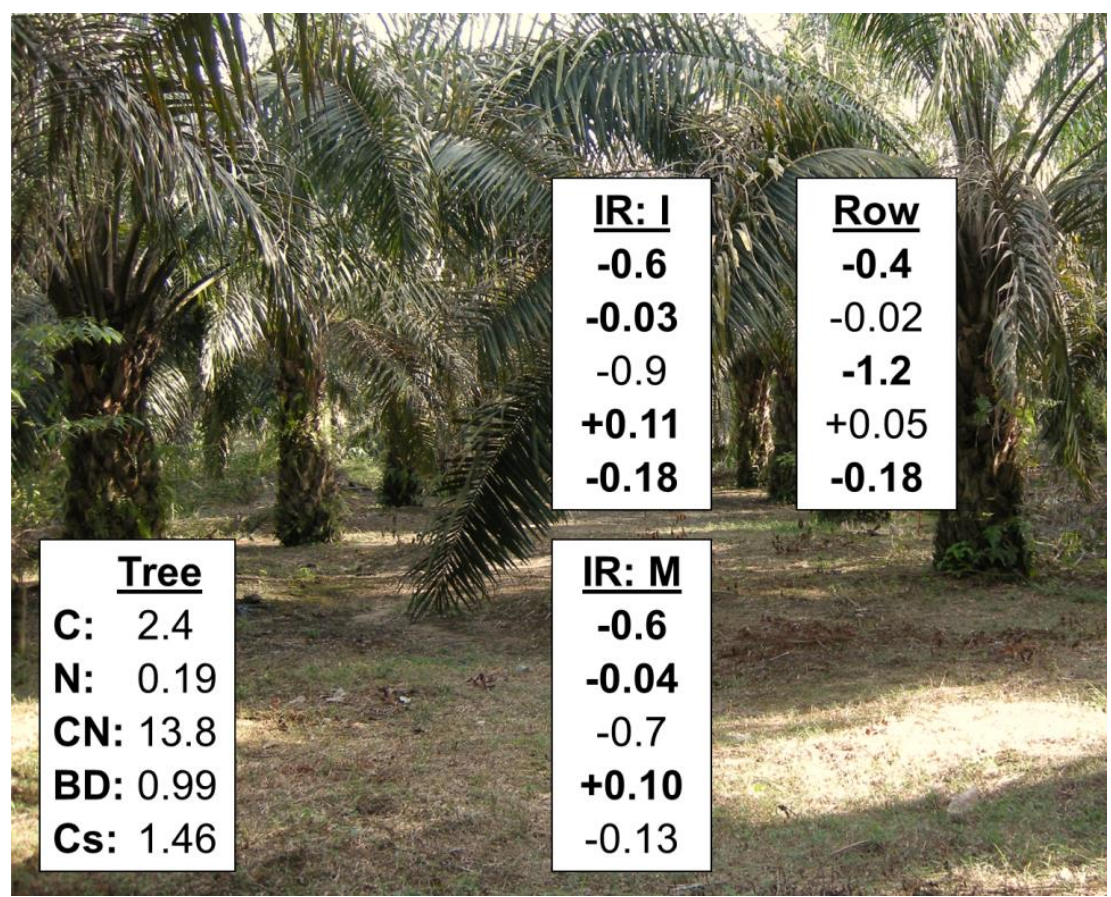

Figure 3-6: Heterogeneity of soil properties within oil palm plantations.

The $\mathrm{C}$ content (C:\%), $\mathrm{N}$ content $(\mathrm{N}: \%), \mathrm{C} / \mathrm{N}$ ratio $(\mathrm{C} / \mathrm{N})$, bulk density (BD: $\mathrm{g} \mathrm{cm}-3)$ and SOC stocks $(\mathrm{Cs}: \mathrm{kg} \mathrm{m}-2)$ at $0-5 \mathrm{~cm}$ depth beside the trees are presented against the difference of the soil properties in rows and inter-rows between two trees (IR:I) and between four trees (IR:M). Bold values indicate significant differences $(\mathrm{p}<0.05$, linear mixed effect model) between the soil beside trees and the other locations.

Only oil palm plantations showed differences in the soil properties depending on the sampling location i.e. beside trees, in rows, in interrows between trees or at the midpoint between four trees (Fig. 3-6). The soil properties under intensive and extensive rubber plantations were homogenous. According to the standard deviation of the $\mathrm{C}$ content between sampling locations (SD: $1.4 \%$ ), the probability (power) to detect a difference in $\mathrm{C}$ content of $0.3 \%$ between two locations in the intensive rubber plantations was $80 \%$. While the $\mathrm{C}$ contents beside trees and at the midpoint between four trees under rubber did not differ more than $0.2 \pm 0.1 \%$, this difference under oil palm plantations reached $0.6 \pm 0.2 \%$. Under oil palm plantations, the soil beside trees had higher $\mathrm{C}$ and $\mathrm{N}$ contents, higher $\mathrm{C}$ stocks, higher $\mathrm{C} / \mathrm{N}$ ratio and lower bulk density than in interrows (Fig. 3-6). The soil properties of the two locations in interrows (between trees or at the 
midpoint between four trees) were similar. The soil in oil palm rows tended to be less degraded than in the interrows, but these differences were not significant. The seven oil palm plantations with high soil variability did not show any trends relating to plantation structure. Thus, the oil palm plantations showed a high heterogeneity of soil conditions not only between plantations, but also within a single plantation. 


\subsubsection{Discussion}

The $\mathrm{C}$ content in the top $5 \mathrm{~cm}$ (Ah horizon) of well-drained soils from four tropical forest units in Jambi province ranged from 5.3 to 9\% (Ishizuka et al., 2005; Guillaume et al., 2015). Therefore, the majority of plantations had less than half of the topsoil $\mathrm{C}$ content under forest (3.7 for intensive, $3.5 \%$ for extensive rubber and $2.2 \%$ for oil palm). On the other hand, $19 \%$ of oil palm plantations and $3 \%$ of intensive rubber plantations had a $\mathrm{C}$ content higher than the range found under forest.

\section{High C content under plantations}

The plantations with high soil $\mathrm{C}$ content were most likely established on peats or on soils experiencing regular waterlogging conditions. Since the late 90s, peatland deforestation driven by smallholders in Sumatra and Jambi province in particular has been observed by satellite imagery (Miettinen et al., 2012b; Lee et al., 2014). While none of the extensive rubber plantations were established on such soils, it was a common practice for oil palm and a rare practice for intensive rubber plantations. Extensive rubber was the initial type of plantation to be developed in the province and nowadays new plantations are rarely established (Feintrenie et al., 2010). Prior to land scarcity, farmers most likely selected well-drained sites with high C content and fertility, resulting in a narrow range of $\mathrm{C}$ content under extensive rubber. In contrast, oil palm cultivation by smallholders started when rubber was already a well-established cash crop, and unutilized land was scarce. Indeed, the intensification of rubber cultivation had already reached its peak before the oil palm boom. Since 1996, the area under rubber has increased by only a quarter, while the area under oil palm quadrupled (Euler et al., 2015a). Therefore, the scarcity of unutilized land pushed farmers to establish oil palm plantations in marginal areas, such as peat or riparian zones, more frequently than in the past. Indeed, nearly all industrial plantations on peatlands were established in the last 20 years (Miettinen et al., 2012a). Large wetland clearing on Sumatra was attributed to an expansion by private companies from lowland to wetland regions (Margono et al., 2014). Our study shows that a similar trend operates at the smallholder level. Furthermore, this expansion is not only into wetland regions, but also into marginal riparian sites within landscapes dominated by well-drained soils, which has not been taken into account by studies using satellite imagery. 


\section{Low $C$ content under plantations}

Despite the fact that oil palm cultivation was not necessarily associated with higher soil degradation than rubber cultivation, highly degraded soils with low $\mathrm{C}$ content and high bulk density were an exception under rubber, but frequent under oil palms. In contrast to oil palms, the introduction of rubber cultivation resulted in similar soil degradation all over Jambi province, including Batanghari and Muaro Jambi regencies, which account for $82 \%$ of the sampled oil palm plantations. The impact of the land-use type (rubber and oil palm) on the SOC was compared in Indonesia, Cameroon and Peru, on plantations with similar soils and land-use history, and compared with forest sites as references (Allen et al., 2015; Guillaume et al., 2015; van Straaten et al., 2015). While the SOC losses were high and tended to be higher under oil palm plantations, the difference between plantation types was small and generally not significant. Therefore, a high frequency of oil palm soils in an advanced degraded stage is explained by their frequent establishment on soils already degraded by previous use. Indeed, while smallholders' oil palm plantations are not substituting for intensive rubber plantations because of the income loss during the conversion period (Euler et al., 2015a), they are frequently established on extensive rubber or fallow land (Gatto et al., 2015). Therefore, the scarcity of unutilized land resources during the oil palm boom not only led farmers in the Jambi province to establish new plantations on soils with high $\mathrm{C}$ content but also on already degraded soils.

\section{Impact of land-use type}

The land-use intensity in rubber plantations had no effect on the SOC quantity and quality, but only on the soil compaction. Higher bulk densities under intensive rubber in Jambi Province were previously reported (Allen et al., 2015). They are explained by greater soil erosion due to reduced groundcover (Guillaume et al., 2015) and by increased soil compaction by more intense trampling due to the higher rubber tree density and harvesting frequency.

The high variability of the initial soil conditions of oil palm plantations hides the effect of the plantation type. Nevertheless, independently of the initial soil conditions, the specific structure and management of oil palm plantations resulted in additional $\mathrm{C}$ losses and soil compaction in the inter rows and, to a lesser extent, in the rows. Various mechanisms explain a more negative impact and a higher soil heterogeneity under oil palm than under rubber plantations: i) despite 
similar net primary production remaining in both plantation types (Kotowska et al., 2015), the concentration of leaf litter $\mathrm{C}$ in frond piles slightly increases the SOC stocks in this location (Haron et al., 1998; Carron et al., 2015), but leaves the majority of the plantation area with only the root-derived $\mathrm{C}$. Thus, ii) the increasing distance from the trees results in a decrease of rootderived C input, and hence of SOC (Frazão et al., 2013). Additionally, iii) soil erosion is the most common mechanism of SOC loss in oil palm plantations (Gharibreza et al., 2013; Guillaume et al., 2015). Erosion is more intense in inter rows because of reduced canopy cover and higher runoff intensity after strong rainfall events. Furthermore, in the oil palm plantations, farmers use trucks or pickups for collecting the fresh fruit bunches, increasing the soil compaction in inter rows. In contrast, no heavy vehicles are used in rubber plantations.

Further studies focusing on the site history, establishment and management practices of the plantations are necessary to disentangle the influential factors and their relative impacts on soil quality under oil palm plantations, as well as their variability between regencies. The trend towards agricultural intensification on peatland, riparian zones or degraded soils confirms the land scarcity already observed in 1) an increasing proportion of wetland forest loss, as revealed by satellite images (Margono et al., 2014), 2) a decrease of forest area under concessions (Abood et al., 2015) and 3) a decrease of oil palm adoption rate by farmers (Euler et al., 2015a).

\section{Environmental impacts}

The Jambi province illustrates a new stage of agricultural intensification in the tropics, in which agricultural intensification is achieved mostly by land-use intensification, rather than by conversion of natural ecosystems to agroecosystems (Gibbs et al., 2010). Converting the remaining forests in marginal areas such as peatlands or riparian areas is a regression in terms of agricultural resource-use efficiency. Because of the large amount of $\mathrm{C}$ stored in such soils (Hooijer et al., 2010), the greenhouse gas emissions per area are much higher than for the conversion of well-drained mineral soils (Carlson et al., 2012). The increasing area of tropical peatland converted to plantations and the related concerns about greenhouse gas emissions have been underlined by numerous studies (Hergoualc'h \& Verchot, 2011; Hirano et al., 2012; Miettinen et al., 2012a; Melling et al., 2013; Nurulita et al., 2014). The increasing conversion of mineral soils with high $\mathrm{C}$ content in riparian areas, however, is a new trend underlined by this 
study that exacerbates the challenges of mitigating greenhouse gas emissions from land-use change.

The $\mathrm{C}$ content and compaction in the majority of oil palm plantations is a source of concern. The microbial activity under oil palm, intensive and extensive rubber plantations in the regency of Batanghari was resistant to SOC losses down to $2.7 \% \mathrm{C}$, but strongly decreased below this threshold (Guillaume et al., 2016). Although this threshold might change depending on soil type, the majority of soil under oil palm was far below this limit. Furthermore, a bulk density of $1.3 \mathrm{~g}$ cm-3 is close to that in Bt horizons, i.e. horizons of clay accumulation in the subsoil (Allen et al., 2015), where water percolation is strongly reduced, further increasing the risk of erosion through runoff and decreasing groundwater recharge (Bruijnzeel, 2004). Thus, we observed a strong loss of ecosystem services (C sequestration, water storage and infiltration, nutrient cycling) in soils under oil palm. After the disturbance induced by land-use change, the $\mathrm{C}$ content should stabilize to reach a new equilibrium corresponding to the new biophysical conditions in the plantations (Smith et al., 2012; de Blécourt et al., 2013; van Straaten et al., 2015). Considering the high frequency of soils with less than $1 \% \mathrm{C}$ content, the soils degradation has not stabilized yet. The erosion observed in mature plantations (Gharibreza et al., 2013) and the re-establishment of new plantations on previously degraded soils might prevent a replenishment of the SOC stocks. This raises major concerns about the sustainability of tropical agricultural intensification and the success of the 2nd oil palm generation that is now starting after some 30 years of oil palm

cultivation on Sumatra Island. Tropical agricultural intensification in the context of land scarcity has not only a global negative impact associated with losses of carbon sequestration in soil and high greenhouse gas emissions, but also a local negative impact associated with the loss of soil fertility. Because the Sumatra Island and especially the Jambi province are the pioneers of landuse change in Indonesia, with high land scarcity, the results are highly relevant not only regionally, but should be regarded as threats that the islands of Kalimantan and Papua, as well as many other tropical regions, will face in the near future.

\subsubsection{Acknowledgments}

This study was funded by the Deutsche Forschungsgemeinschaft (DFG) in the framework of the collaborative German - Indonesian research project CRC990. This study was conducted using samples collected based on collection permit No. S.305/KKH-2/2013 recommended by the 
Indonesian Institute of Sciences (LIPI) and issued by the Ministry of Forestry (PHKA). We thank the village leaders and the plot owners for granting us access to and use of their properties, the Indonesian assistants for their help in collecting and preparing samples. We thank Vijesh Krishna for providing information on the villages in the province, Niklas Rehkopp for providing the province map and Kyle Mason for its comments on the manuscript.

\subsubsection{References}

Abood S a., Lee JSH, Burivalova Z, Garcia-Ulloa J, Koh LP (2015) Relative contributions of the logging, fiber, oil palm, and mining industries to forest loss in Indonesia. Conservation Letters, 8, 58-67.

Allen K, Corre MD, Tjoa A, Veldkamp E (2015) Soil Nitrogen-cycling responses to conversion of lowland forests to oil palm and rubber plantations in Sumatra, Indonesia. PLoS ONE, 10, e0133325.

Barnes AD, Jochum M, Mumme S, Haneda NF, Farajallah A, Widarto TH, Brose U (2014) Consequences of tropical land use for multitrophic biodiversity and ecosystem functioning. Nature Communications, 5, 1-7.

De Blécourt M, Brumme R, Xu J, Corre MD, Veldkamp E (2013) Soil Carbon Stocks Decrease following Conversion of Secondary Forests to Rubber (Hevea brasiliensis) Plantations. PLoS ONE, 8, e69357.

Bruijnzeel LA (2004) Hydrological functions of tropical forests: Not seeing the soil for the trees? Agriculture, Ecosystems and Environment, 104, 185-228.

Carlson KM, Curran LM, Asner GP, Pittman AM, Trigg SN, Marion Adeney J (2012) Carbon emissions from forest conversion by Kalimantan oil palm plantations. Nature Climate Change, 3, 283-287.

Carron MP, Auriac Q, Snoeck D et al. (2015) Spatial heterogeneity of soil quality around mature oil palms receiving mineral fertilization. European Journal of Soil Biology, 66, 24-31.

Euler M, Schwarze S, Siregar H, Qaim M (2015a) Oil palm expansion among smallholder farmers in Sumatra, Indonesia. EFForTS Discussion Paper series 8, Georg-AugustUniversität, Göttingen, Germany. 
Euler M, Krishna V, Schwarze S, Siregar H, Qaim M (2015b) Oil palm adoption, household welfare and nutrition among smallholder farmers in Indonesia. EFForTS Discussion Paper series 12, Georg-August-Universität, Göttingen, Germany.

FAOSTAT Production / Crops: Oil, palm fruit.

Faust H, Schwarze S, Beckert B et al. (2013) Assessment of socio-economic functions of tropical lowland sampling framework and methodological approach. EFForTS Discussion Paper series 1, Georg-August-Universität, Göttingen, Germany.

Feintrenie L, Schwarze S, Levang P (2010) Are local people conservationists? Analysis of transition dynamics from agroforests to monoculture plantations in Indonesia. Ecology and Society, 15, 37.

Frazão LA, Paustian K, Pellegrino Cerri CE, Cerri CC (2013) Soil carbon stocks and changes after oil palm introduction in the Brazilian Amazon. GCB Bioenergy, 5, 384-390.

Gatto M, Wollni M, Qaim M (2015) Oil palm boom and land-use dynamics in Indonesia: The role of policies and socioeconomic factors. Land Use Policy, 46, 292-303.

Gharibreza M, Raj JK, Yusoff I, Othman Z, Tahir WZWM, Ashraf MA (2013) Land use changes and soil redistribution estimation using $137 \mathrm{Cs}$ in the tropical Bera Lake catchment, Malaysia. Soil and Tillage Research, 131, 1-10.

Gibbs HK, Ruesch a S, Achard F, Clayton MK, Holmgren P, Ramankutty N, Foley J a (2010) Tropical forests were the primary sources of new agricultural land in the 1980s and 1990s. Proceedings of the National Academy of Sciences of the United States of America, 107, 16732-16737.

Guillaume T, Damris M, Kuzyakov Y (2015) Losses of soil carbon by converting tropical forest to plantations: Erosion and decomposition estimated by $\delta 13 \mathrm{C}$. Global Change Biology, $21,3548-3560$.

Hansen MC, Potapov PV, Moore R, Hancher M, Turubanova SA, Tyukavina A (2013) HighResolution Global Maps of 21st Century Forest Cover Change. Science, 342, 850-853. 
Haron K, Brookes PC, Anderson JM, Zakaria ZZ (1998) Microbial biomass and soil organic matter dynamics in oil palm (Elaeis guineensis jacq.) plantations, West Malaysia. Soil Biology and Biochemistry, 30, 547-552.

Hergoualc'h K, Verchot LV (2011) Stocks and fluxes of carbon associated with land use change in Southeast Asian tropical peatlands: A review. Global Biogeochemical Cycles, 25, 1-13.

Hirano T, Segah H, Kusin K, Limin S, Takahashi H, Osaki M (2012) Effects of disturbances on the carbon balance of tropical peat swamp forests. Global Change Biology, 18, 3410-3422.

Hooijer a., Page S, Canadell JG, Silvius M, Kwadijk J, Wösten H, Jauhiainen J (2010) Current and future CO 2 emissions from drained peatlands in Southeast Asia. Biogeosciences, 7, $1505-1514$.

Ishizuka S, Iswandi A, Nakajima Y, Yonemura S, Sudo S, Tsuruta H, Murdiyarso D (2005) The variation of greenhouse gas emissions from soils of various land-use/cover types in Jambi province, Indonesia. Nutrient Cycling in Agroecosystems, 71, 17-32.

IUSS Working Group WRB (2014) World reference base for soil resources 2014, Vol. 106. FAO, Rome, 1-191 pp.

Kotowska MM, Leuschner C, Triadiati T, Meriem S, Hertel D (2015) Quantifying above- and belowground biomass carbon loss with forest conversion in tropical lowlands of Sumatra (Indonesia). Global Change Biology, 10.1111/gcb.12979.

Lal R (2010) Enhancing Eco-efficiency in Agro-ecosystems through Soil Carbon Sequestration. Crop Science, 50, 120-131.

Lambin EF, Meyfroidt P (2011) Global land use change, economic globalization, and the looming land scarcity. Proceedings of the National Academy of Sciences of the United States of America, 108, 3465-3472.

Laumonier Y, Uryu Y, Stüwe M, Budiman A, Setiabudi B, Hadian O (2010) Eco-floristic sectors and deforestation threats in Sumatra: identifying new conservation area network priorities for ecosystem-based land use planning. Biodiversity and Conservation, 19, 1153-1174. 
Lee JSH, Abood S, Ghazoul J, Barus B, Obidzinski K, Koh LP (2014) Environmental impacts of large-scale oil palm enterprises exceed that of smallholdings in Indonesia. Conservation Letters, 7, 25-33.

Margono BA, Potapov P V., Turubanova S, Stolle F, Hansen MC (2014) Primary forest cover loss in Indonesia over 2000-2012. Nature Climate Change, 4, 730-735.

McCarthy JF, Cramb RA (2009) Policy narratives, landholder engagement, and oil palm expansion on the Malaysian and Indonesian frontiers. Geographical Journal, 175, 112-123.

Melling L, Yun Tan CS, Goh KJ, Hatano R (2013) Soil microbial and root respirations from three ecosystems in tropical peatland of sarawak, Malaysia. Journal of Oil Palm Research, $25,44-57$.

Miettinen J, Hooijer A, Shi C et al. (2012a) Extent of industrial plantations on Southeast Asian peatlands in 2010 with analysis of historical expansion and future projections. GCB Bioenergy, 4, 908-918.

Miettinen J, Hooijer A, Wang J, Shi C, Liew SC (2012b) Peatland degradation and conversion sequences and interrelations in Sumatra. Regional Environmental Change, 12, 729-737.

Nurulita Y, Adetutu EM, Kadali KK, Zul D, Mansur A a., Ball AS (2014) The assessment of the impact of oil palm and rubber plantations on the biotic and abiotic properties of tropical peat swamp soil in Indonesia. International Journal of Agricultural Sustainability, 13, 150166.

Schwarze S, Euler M, Gatto M et al. (2015) Rubber vs. oil palm: an analysis of factors influencing smallholders' crop choice in Jambi, Indonesia. EFForTS Discussion Paper series 11, Georg-August-Universität, Göttingen, Germany.

Smith DR, Townsend TJ, Choy AWK, Hardy ICW, Sjögersten S (2012) Short-term soil carbon sink potential of oil palm plantations. GCB Bioenergy, 4, 588-596.

Van Straaten O, Corre MD, Wolf K, Tchienkoua M, Cuellar E, Matthews RB, Veldkamp E (2015) Conversion of lowland tropical forests to tree cash crop plantations loses up to onehalf of stored soil organic carbon. Proceedings of the National Academy of Sciences, 112, 9956-9960. 
Tilman D, Fargione J, Wolff B et al. (2001) Forecasting agriculturally driven global environmental change. Science, 292, 281-284.

Vitousek PM (1984) Litterfall, Nutrient Cycling, and Nutirent Limitation in Tropical Forests. Ecology, 65, 285-298.

Wilcove DS, Koh LP (2010) Addressing the threats to biodiversity from oil-palm agriculture. Biodiversity and Conservation, 19, 999-1007. 


\subsection{Study 2}

\section{Losses of soil carbon by converting tropical forest to plantations: Erosion and decomposition estimated by $\delta^{13} \mathrm{C}$}

Thomas Guillaume $^{1 *}$, Damris Muhammad ${ }^{2}$, Yakov Kuzyakov $^{1}$

${ }^{1}$ Department of Soil Science of Temperate Ecosystems, and Department of Agricultural Soil

Science, Georg-August-University of Göttingen, Germany

${ }^{2}$ Faculty of Engineering, University of Jambi, Indonesia

Status: published in Global Change Biology

Guillaume T, Damris M, Kuzyakov Y (2015) Losses of soil carbon by converting tropical forest to plantations: Erosion and decomposition estimated by $\delta^{13} \mathrm{C}$. Global Change Biology, 21, $3548-3560$.

*Corresponding Author:

Georg-August-University of Göttingen

Department of Soil Science of Temperate Ecosystems

Büsgenweg 2

37077 Göttingen, Germany

Tel. + 495513922061 Fax + 49551393310 ,

email: thoguillaume@gmail.com 


\subsubsection{Abstract}

Indonesia lost more tropical forest than all of Brazil in 2012, mainly driven by the rubber, oil palm and timber industries. Nonetheless, the effects of converting forest to oil palm and rubber plantations on soil organic carbon (SOC) stocks remain unclear. We analyzed SOC losses after lowland rainforest conversion to oil palm, intensive rubber and extensive rubber plantations in Jambi province on Sumatra Island. The focus was on two processes: 1) erosion and 2) decomposition of soil organic matter. Carbon contents in the Ah horizon under oil palm and rubber plantations were strongly reduced: up to $70 \%$ and $62 \%$, respectively. The decrease was lower under extensive rubber plantations (41\%). On average, converting forest to plantations led to a loss of $10 \mathrm{Mg} \mathrm{C} \mathrm{ha}^{-1}$ after about 15 years of conversion. The $\mathrm{C}$ content in the subsoil was similar under the forest and the plantations. We therefore assumed that a shift to higher $\delta^{13} \mathrm{C}$ values in plantation subsoil corresponds to the losses from the upper soil layer by erosion. Erosion was estimated by comparing the $\delta^{13} \mathrm{C}$ profiles in the soils under forest and under plantations. The estimated erosion was the strongest in oil palm $(35 \pm 8 \mathrm{~cm})$ and rubber $(33 \pm 10$ $\mathrm{cm})$ plantations. The ${ }^{13} \mathrm{C}$ enrichment of SOC used as a proxy of its turnover indicates a decrease of SOC decomposition rate in the Ah horizon under oil palm plantations after forest conversion. Nonetheless, based on the lack of $\mathrm{C}$ input from litter, we expect further losses of SOC in oil palm plantations, which are a less sustainable land-use compared to rubber plantations. We conclude that $\delta^{13} \mathrm{C}$ depth profiles may be a powerful tool to disentangle soil erosion and SOC mineralization after the conversion of natural ecosystems conversion to intensive plantations when soils shows gradual increase of $\delta^{13} \mathrm{C}$ values with depth. 


\subsubsection{Introduction}

Tropical rainforest area is decreasing worldwide through deforestation and transformation into agricultural systems. Between 1985 and 2007, Sumatra Island (Indonesia) lost half of its remaining natural rainforest, which currently covers a mere $30 \%$ of the island (Laumonier et al., 2010; Wilcove \& Koh, 2010). In 2012, the area of natural rainforest loss was higher in Indonesia than in Brazil (Margono et al., 2014). This deforestation is still ongoing, mainly driven by the oil palm, rubber, mining, timber and pulp industries (Laumonier et al., 2010; Abood et al., 2014). The present study is motivated by the need to quantify soil organic carbon (SOC) stocks changes after tropical forest conversion and to elucidate the involved processes.

Land-use changes in tropical ecosystems lead to major modifications of soil properties and processes (Ross, 1993; McGrath et al., 2001). Among them, loss of SOC is a well-known consequence of converting natural forest to agricultural land (van Noordwijk et al., 1997; Don et al., 2011). Nevertheless, the magnitude, rates and even the direction of the changes in SOC depend on the type of conversion and are still unclear (Guo \& Gifford, 2002; Don et al., 2011; Ziegler et al., 2012). Generalization is difficult due to bias in the locations and conversion types studied (Powers et al., 2011). The authors stressed that the conversion of forest to tree plantations is strongly underrepresented despite the increasing plantation area. Studies on the conversion of lowland tropical forest to rubber and oil palm plantations showed contrasting results with regard to SOC. Significant decreases of SOC under rubber plantations were reported down to $1 \mathrm{~m}$ depth (de Blécourt et al., 2013; Chiti et al., 2014) or only in the topsoil (Schroth et al., 2002; Chiti et al., 2014). In contrast, (Frazão et al., 2013) reported no differences or even slightly higher SOC stocks under oil palm plantations than in the surrounding forest.

Two groups of processes explain the possible reduction of SOC after land-use change (Fig. 3-7): 1) modification of the SOC turnover rate by decreasing the $C$ input or increasing $S O C$ decomposition, and 2) erosion of the C-rich surface layer (Lal, 2001; Don et al., 2011). Forest conversion to plantation reduces the $\mathrm{C}$ input from the above- and belowground litters (Powers, 2004). The decomposition of SOC is enhanced by nutrient release from the dead or burnt biomass and by the labile organic matter released from disturbed soil aggregates during the plantation establishment (Berhe et al., 2007). Soil erosion is strongly increased when forest is 
converted to agricultural land (Islam \& Weil, 2000; Sidle et al., 2006), especially when the soil protective cover (litter layer and canopy) is removed (Ross \& Dykes, 1996).

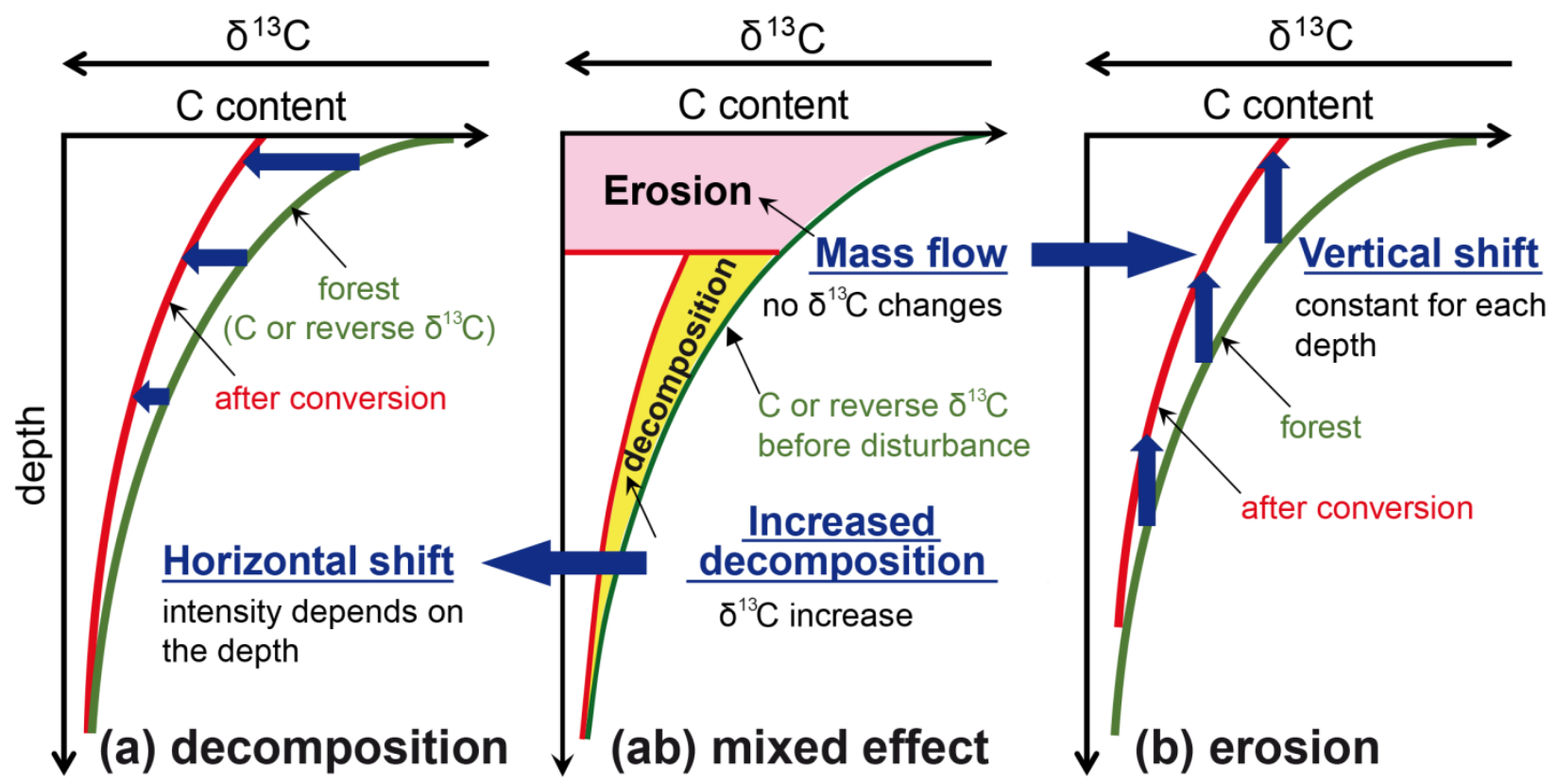

Figure 3-7: Impact of forest conversion on the $\mathrm{C}$ content and $\delta^{13} \mathrm{C}$ distributions in the soil depths (ab); separated by decomposition (a) and erosion (b).

Decomposition of SOC directly affects its isotopic composition. Firstly, kinetic fractionation occurs because reaction rates are slower for heavy isotopes (e.g. ${ }^{13} \mathrm{C}$ ) than for lighter isotopes (e.g. ${ }^{12} \mathrm{C}$ ), enriching the remaining SOC with heavy isotopes. Isotopic composition is expressed in $\delta$ notation:

$\delta(\% 0)=\left(\frac{R_{\text {sample }}}{R_{\text {standard }}}-1\right) * 1000$

where $\mathrm{R}$ is the molar ratio of heavy to light isotope of the sample or the international PDB limestone standard. Accordingly, ${ }^{13} \mathrm{C}$ enrichment leads to less negative $\delta^{13} \mathrm{C}$ values.

In natural systems, kinetic fractionation leads to a substrate ${ }^{13} \mathrm{C}$ enrichment. This follows a linear function with the logarithm of the fraction of the remaining initial substrate according to a Rayleigh distillation (Mariotti et al., 1981). Secondly, preferential substrate decomposition of substances with different isotopic composition might affect the bulk SOC isotopic signature (Werth \& Kuzyakov, 2010). Individual substances in a plant can differ up to 9\%o (Hobbie \& Werner, 2004). This process, however, should mostly work against a ${ }^{13} \mathrm{C}$ enrichment because 
easily available substances such as glucose are enriched in ${ }^{13} \mathrm{C}$ compared to more refractory substances such as lignin (Hobbie \& Werner, 2004). Despite uncertainties about the mechanisms leading to fractionation during microbial metabolism (Brüggemann et al., 2011), a review by Werth \& Kuzyakov (2010) shows a mean enrichment of $1.2 \%$ in microbial biomass compared to the bulk SOC. The $\delta^{13} \mathrm{C}$ increase during SOC maturation is roughly proportional to the number of cycles in which $\mathrm{C}$ is metabolized by microorganisms (Gunina \& Kuzyakov, 2014).

In general, the $\delta^{13} \mathrm{C}$ increases with soil depth, whereas $\mathrm{C}$ content decreases (Natelhoffer \& Fry, 1988; Balesdent et al., 1993; Garten Jr et al., 2000; Wynn et al., 2005). Various mechanisms were suggested to explain this relative enrichment (Natelhoffer \& Fry, 1988; Balesdent et al., 1993; Ehleringer et al., 2000). The root-to-shoot ratio increases with soil depth, which might enrich SOC with ${ }^{13} \mathrm{C}$ because roots are on average enriched in ${ }^{13} \mathrm{C}$ by $1.2 \%$ compared to shoots (Werth \& Kuzyakov, 2010). The other potential mechanisms are related to the increasing average age of SOC with increasing soil depth (Trumbore, 2000). Decomposition is more advanced in older SOC, leading to a more intense kinetic fractionation with depth. Nonetheless, preferential substrate decomposition should lead to a depletion of ${ }^{13} \mathrm{C}$ with soil depth. Physical mixing favors the migration of smaller and more strongly decomposed SOC particles down the soil profile. This leads to a higher proportion of older and more decomposed SOC in deeper horizons. Finally, changes over time in the litter $\delta^{13} \mathrm{C}$ values would produce a similar trend in the depth profile because SOC is older in deeper soil layers. The Suess effect describes the dilution of ${ }^{13} \mathrm{CO}_{2}$ in the atmosphere due to the burning of fossil fuel (depleted in ${ }^{13} \mathrm{C}$ ) since the Industrial Revolution (Suess, 1955). The maximal amplitude in the soil was 1.1\%o in 1980 (Friedli et al., $1986)$, but is currently around $1.6 \%$.

Garten Jr et al. (2000) found an empirical linear relation between the ${ }^{13} \mathrm{C}$ enrichment and the logtransformed $\mathrm{C}$ content $(\log \mathrm{SOC})$ in well-drained undisturbed soils. Further studies correlated the slope of the regression, termed $\beta$, with SOC turnover (Garten Jr., 2006) or proxies of SOC turnover, e.g. mean annual temperature (MAT) (Garten Jr et al., 2000; Garten Jr., 2006; Campbell et al., 2009; Acton et al., 2013), litter C/N ratio (Garten Jr et al., 2000; Garten Jr., 2006) and soil texture (Powers \& Schlesinger, 2002; Wynn et al., 2005; Acton et al., 2013). More negative $\beta$ (steeper slopes) were associated with higher turnover rates. Studies modeled, using the Rayleigh distillation equation, the depth trend of $\delta^{13} \mathrm{C}$ values in terms of the remaining 
SOC fraction instead of the C content (Wynn et al., 2005, 2006; Garten Jr., 2006; Diochon \& Kellman, 2008). Finally, $\beta$ values were modeled by isotopic mass balance using the Rayleigh distillation equation and incorporating decomposition rate and physical mixing of SOC (Acton $e t$ al., 2013). Only few studies have investigated the effect of soil disturbance on the $\beta$ value (Wynn et al., 2005, 2006; Diochon \& Kellman, 2008; Campbell et al., 2009). Campbell et al. (2009), however, pointed to the potential of comparative studies on disturbed and undisturbed soil to investigate the effect of land-use changes on SOC, and Wynn et al. (2006) hypothesized the effect of decomposition and erosion on the $\beta$ value.

Erosion has no direct impact on the $\delta^{13} \mathrm{C}$ value because soil particles are mechanically transported without any differentiation between ${ }^{13} \mathrm{C}$ and ${ }^{12} \mathrm{C}$. Nevertheless, after the loss of the eroded layer, the new surface layer is composed of a mixture of SOC from the subsoil and fresh $\mathrm{C}$ from the litter. This leads to a different isotopic composition of the new versus old surface layer (Häring et al., 2013), but without effect on the $\delta^{13} \mathrm{C}$ in the subsoil. Furthermore, the $\delta^{13} \mathrm{C}$ depth distribution in the soil profile shifts closer to the soil surface after the loss of the upper layer (Fig. 3-7). Erosion does not modify the $\beta$ values because the regression is independent of soil depth (Wynn et al., 2006).

We investigated the impact of lowland rainforest conversion to tree plantations on the SOC and its isotopic composition. We compared the vertical distribution of $\mathrm{SOC}$ and $\delta^{13} \mathrm{C}$ and $\beta$ values of soils under forest and under plantations to investigate the impact of erosion and SOC decomposition on the decrease of $\mathrm{C}$ stocks due to forest conversion. We hypothesized that SOC losses would increase with land-use intensity. Nevertheless, the effects on $\mathrm{C}$ content and on $\delta^{13} \mathrm{C}$ would be mainly pronounced in the topsoil because of the short period after conversion, leaving the subsoil unaffected. Therefore, we assess erosion by assuming that the $\mathrm{C}$ content and its $\delta^{13} \mathrm{C}$ values in the plantation subsoil were similar to the values in the forest subsoil prior to conversion. Consequently, when an identical subsoil depth has a higher $\delta^{13} \mathrm{C}$ in the plantation than the forest, we suggest that this layer experienced a vertical shift towards the soil surface after erosional loss of the upper layer (Fig. 3-7). Following the hypothesis that the subsoil was unaffected by the land-use change, we assume that the $\beta$ value in the subsoil of the plantation represents the $\beta$ value before the conversion to plantation. Consequently, if the SOC turnover in 
the topsoil was modified by the land-use change, the $\delta^{13} \mathrm{C}$ of the SOC in the plantation topsoil should deviate from the regression line calculated for the plantation subsoil.

In summary, this study was designed 1) to quantify changes of $\mathrm{C}$ content and stocks in soil after conversion of lowland rainforest to extensive rubber, intensive rubber and oil palm plantations, 2) to quantify soil erosion in plantations and 3) to investigate changes in SOC decomposition in plantation topsoils. 


\subsubsection{Materials and Methods}

Study sites

The study was conducted in Jambi Province (Sumatra, Indonesia). The climate is tropical humid $\left(27^{\circ} \mathrm{C} ; 2240 \mathrm{~mm} \mathrm{y}^{-1} ; 112-259 \mathrm{~mm} \mathrm{month}^{-1}\right)$ with a rainy season lasting from October to April. The experimental design includes: natural lowland tropical rainforest and three land-use types dominating in Sumatra: 1) jungle rubber, 2) rubber plantation and 3) oil palm plantation. The design is replicated in 2 regions (called Harapan and Bukit in the manuscript) within the province of Jambi. Soils from both regions were Acrisols with sandy loam texture in Harapan and a clay texture in Bukit region. In each region, a large unit of lowland rainforest was used as reference sites: Harapan Rainforest and National Park Bukit Duabelas. The reference sites are old-growth forests that have been subject to minor logging but are still very close to natural state. Jungle rubber is an agroforest in which rubber trees were extensively planted in partially logged forest.

\section{Experimental plots}

Four replicate sites for each land use in both regions were selected for a total of 32 field plots. Plot altitudes varied between 50-100 m a.s.1 and plot slopes between 3-12\%. On average, oil palm plantations were 14 years old in both regions. Rubber plantations were five years younger in Bukit than the15-year-old Harapan plantations. The age of jungle rubber ranged from 16 to 42 years. The jungle rubber ages, however, indicate the minimal ages; i.e. when the farmer received/bought the land or as far as the farmer could remember. Except for one oil palm site in Bukit (BO1), all rubber and oil palm plantations were smallholding plantations. Usually, rubber and oil palm plantations are established by burning the land after timber extraction. Soils are not tilled but no measures against erosion are taken by smallholders. The understory vegetation was absent or sparse, leaving the soil mostly bare in oil palm plantations and sparsely covered with leave litter in rubber plantations. 


\section{Soil sampling}

For each replicate site, one soil pit was dug between October and November 2012. Soils were described and sampled by horizons to a maximum depth of $100 \mathrm{~cm}$. The bottom limit was set at the maximum depth at which soils dry during the dry season. This corresponds to the start of soft iron-clay concretions and/or a grey-red pattern reflecting reallocation of iron due to reductionoxidation processes. For horizons less than $15 \mathrm{~cm}$ thick (mostly Ah and E horizons), the samples were taken from the whole horizon. For horizons thicker than $15 \mathrm{~cm}$, samples were taken in the middle. After collection, soils were air-dried for 2-3 weeks, sieved at $2 \mathrm{~mm}$ to remove the root residues and to homogenize the samples, and prepared for total $\mathrm{C}$ and $\mathrm{N}$ contents and $\delta^{13} \mathrm{C}$ analyses. If present, $200 \mathrm{~g}$ of litter layers (OL: organic horizon with fresh plant residues; OF: organic horizon with fractionated plant residues) were collected beside the soil pit. There was no litter layer in the oil palm plantations. Therefore, we collected litter samples on the top (OL samples) and bottom (OF samples) of frond piles.

Bulk density has been measured by another research project in adjacent pits in each 32 sites at 5 , 20, 40, and $75 \mathrm{~cm}$ depth. Two-hundred-fifty $\mathrm{cm}^{3}$ cylinders were inserted horizontally from the side of the pit, dried and weighed.

\section{Sample analysis}

Total $\mathrm{C}$ and $\mathrm{N}$ contents as well as $\delta^{13} \mathrm{C}$ values (in \%o of VPDB) were measured on grinded and oven-dried ( $105{ }^{\circ} \mathrm{C}$ overnight) soil and litter samples. Root residues were carefully removed before grinding. Five to forty $\mathrm{mg}$ of soil (depending on the $\mathrm{C}$ and $\mathrm{N}$ content) were weighed in tin capsules. Measurements were done at the Center for Stable Isotope Research and Analysis (KOSI) of the University of Göttingen with an Elemental Analyser (Eurovector) coupled to an Isotope Ratio Mass Spectrometer (Delta plus, Thermo Fisher). Two acetanilid standard were measured every 12 samples. The analytical precision was lower than $0.15 \%$. Since no carbonates were present in the soils, total $\mathrm{C}$ reflects organic $\mathrm{C}$.

\section{Calculations and statistics}

In order to compare and to present soil profiles with different horizon depths, $\mathrm{C}$ and $\mathrm{N}$ contents, $\mathrm{C} / \mathrm{N}$ ratio and $\delta^{13} \mathrm{C}$ values were recalculated for fixed depths $(20,35$ and $55 \mathrm{~cm}$ for all soils and 
80 and 100 for the deepest soils). For the calculation, the $\mathrm{C}$ and $\mathrm{N}$ contents, $\mathrm{C} / \mathrm{N}$ ratio and $\delta^{13} \mathrm{C}$ values in between two adjacent sampling depths were calculated assuming a linear change of the variables in the subsoil between the two sampling depths:

$v_{1}+\left(v_{1}-v_{2}\right) * \frac{d_{f}-d_{2}}{d_{1}-d_{2}}=v_{f}$

where $v_{1}, v_{2}$ and $v_{f}$ are, respectively, the variable values of the two samples adjacent to the fixed depth and the recalculated value of the fixed depth. $d_{1}, d_{2}$ and $d_{f}$ are the respective depths of the two samples and the fixed depth. The samples used for the calculation were those directly above and below the fixed depth. When the sample above the fixed depth was the Ah horizon, we chose the two next samples below that fixed depth. Ah horizons were not used for calculations in order to avoid overestimating the variable due to the strong decrease of all parameters between this organo-mineral horizon and the mineral horizons. Values of Ah horizons were not recalculated but were the measured values of the samples.

$\mathrm{C}$ stocks were calculated by multiplying the $\mathrm{C}$ content with the respective bulk density. If a layer could not be sampled (AE horizon or thin horizons), the $\mathrm{C}$ content for that layer was calculated by equation 2 .

Statistics were performed by the open source software R version 2.15.2. Because of differences in plantation ages and small variations of soil textures, we tested land-use effects for each region separately. We assessed the effect of land-use intensity on $\mathrm{C}$ and $\mathrm{N}$ content, $\delta^{13} \mathrm{C}, \mathrm{C} / \mathrm{N}$ ratio and $\mathrm{C}$ stocks values within a region by using a priori comparisons of least squares means. Three contrast comparisons were set to reflect land-use intensity: 1) forest vs. tree plantations (jungle rubber, rubber, oil palm), 2) extensive (jungle rubber) vs. intensive tree plantations (rubber and oil palm) and 3) rubber vs. oil palm plantations. Tests were performed on Ah horizon and three fixed soil depths $(20,35,55 \mathrm{~cm})$ and on stocks from 0-10, 0-30 and 0-50 cm depths. We assessed region effect on $\mathrm{C}$ and $\mathrm{N}$ contents, $\delta^{13} \mathrm{C}, \mathrm{C} / \mathrm{N}$ ratio and $\mathrm{C}$ stocks for 1) forest soils and 2) tree plantations by performing t-tests with region as grouping factor. t-tests were performed on the same four depths as previously and on the $0-30 \mathrm{~cm}$ stocks.

The relation between $\delta^{13} \mathrm{C}$ and the logarithm in base 10 of $\mathrm{C}$ content (logSOC) was investigated by linear regression for each soil. The slope of the regression is defined as the $\beta$ value. The 
power functions associated with the decrease of $\mathrm{C}$ content or to the increase of $\delta^{13} \mathrm{C}$ with depth were fitted in Statistica 10 using the following equation:

$\mathrm{C}(\mathrm{d})=\mathrm{C}(\mathrm{Ah}) \mathrm{d}^{\mathrm{k}}$

$\delta^{13} \mathrm{C}(\mathrm{d})=\delta^{13} \mathrm{C}(\mathrm{Ah}) \mathrm{d}^{1}$

where $C(d), \delta^{13} C(d), C(A h)$ and $\delta^{13} C(A h)$ are the $\mathrm{C}$ content and the $\delta^{13} \mathrm{C}$ value estimated for the depth $d$ and measured in the Ah horizon, respectively, $d$ the depth in $\mathrm{cm}$ and $k$ and $l$ the fitted parameters of the functions. Regressions were fitted using all samples below the Ah horizon. Carbon content and $\delta^{13} \mathrm{C}$ value were the measured values at the sample collection depth.

Erosion in Harapan region was calculated using the power function describing the distribution of $\delta^{13} \mathrm{C}$ with soil depth in the forest soils. However, this approach was not possible in Bukit region (see result section). Assuming that the shift in $\delta^{13} \mathrm{C}$ in the plantation subsoil resulted from shift in the depth due to the erosion after conversion, we calculated the original depth before erosion for all samples under plantations by modifying equation 3 :

$d_{b}=10^{\frac{\log _{10}\left(\delta 13 C_{d} / \delta 13 C_{A h}\right)}{-l}}$

where $d_{b}$ is the estimated depth before the conversion to plantation, $\delta^{13} C_{d}$ is the $\delta^{13} \mathrm{C}$ values of the samples under plantation at depth $\mathrm{d}, \delta^{13} C_{\mathrm{A} h}$ is the mean $\delta^{13} \mathrm{C}$ values of the Ah horizons under forest, and $l$ is the parameters $l$ estimated for the soils under forest (on all four sites together). The difference between the estimated depth before conversion $\left(d_{b}\right)$ and depth at which the sample was collected (d) corresponds to erosion. The erosion for one pit was calculated by averaging the erosion estimated for each sample collected in the pit. We excluded Ah horizons and samples deeper than $77 \mathrm{~cm}$, which corresponds to the deepest sample under forest.

Data are presented as the mean of four replicates \pm standard error (SE). If not specified, discussed differences are significant at least at a p-value level of $<0.05$. 


\subsubsection{Results}

\section{Effect of region and land use on $C$ and $N$ contents}

Significant differences in $\mathrm{C}$ and $\mathrm{N}$ content between land uses were observed only in the topsoil (Ah horizon). The $\mathrm{C}$ content in Ah horizons of soils under plantations was lower than under forest reference sites (Fig. 3-8). In Harapan region, forest sites had a mean $\mathrm{C}$ and $\mathrm{N}$ contents of $6.8 \pm 0.8 \%$ and $0.43 \pm 0.04 \%$, respectively. Carbon and $\mathrm{N}$ contents in intensive land-uses (oil palm and rubber plantations) were strongly reduced: up to $70 \%$ in oil palm and $62 \%$ in rubber plantations. The values, however, were not significantly different between oil palm and rubber plantations. The decrease of $\mathrm{C}$ and $\mathrm{N}$ contents was less strong in jungle rubber than in rubber and oil palm plantations, indicating an effect of land-use intensity on $\mathrm{C}$ and $\mathrm{N}$ losses in Harapan region (Fig. 3-8).

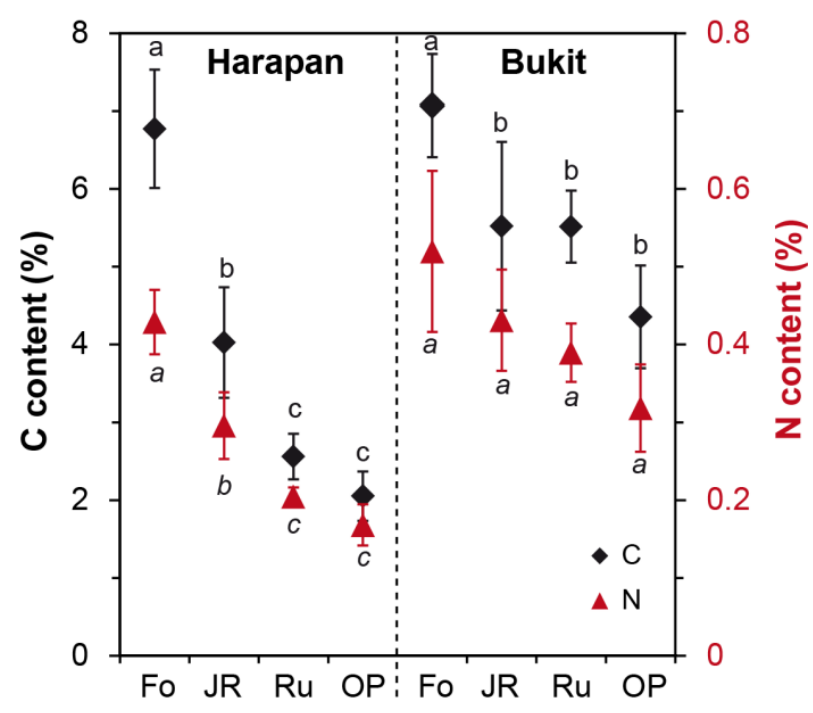

Figure 3-8: Carbon and nitrogen contents in the Ah horizons under (Fo) forest, (JR) jungle rubber, (Ru) rubber and (OP) oil palm plantations in Harapan and Bukit regions.

Values represent means $\pm \mathrm{SE}(\mathrm{n}=4)$. Different letters show statistically significant differences (ANOVA, $\mathrm{p}<0.05$ ).

Their decrease in Bukit plantations followed a similar trend as in Harapan (forest > jungle rubber $>$ rubber > oil palm) except that the $\mathrm{C}$ content was similar under rubber and jungle rubber. Nevertheless, the $\mathrm{C}$ content in Bukit region was significantly reduced only between forest sites and the mean $\mathrm{C}$ content of all plantations, but not between the plantations. There were no differences in $\mathrm{N}$ content between land uses. 
The $\mathrm{C}$ and $\mathrm{N}$ contents in Ah horizons under forest were similar in both regions. The mean decrease of $\mathrm{C}$ content in the Bukit plantations (27.5\%) was much lower than in Harapan (57.5\%). The $\mathrm{C}$ and $\mathrm{N}$ contents in subsoil (under the Ah horizon) of Bukit were similar between land uses but up to 2 times higher than in Harapan subsoils (Fig. 3-9).

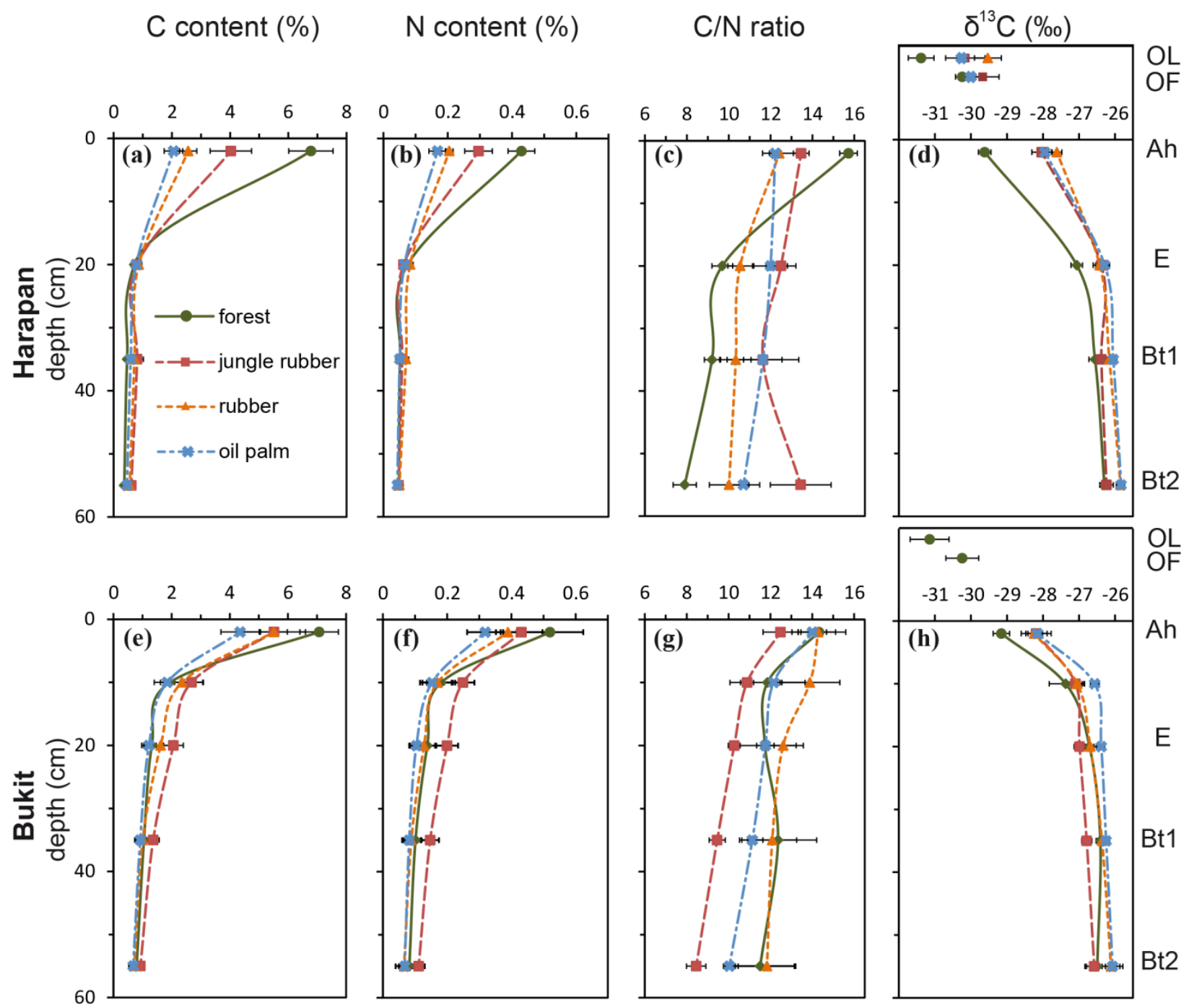

Figure 3-9: Soil characteristic distributions with soil depth.

$(\mathbf{a}, \mathbf{e})$ Carbon content, $(\mathbf{b}, \mathbf{f})$ nitrogen content, $(\mathbf{c}, \mathbf{g}) \mathrm{C} / \mathrm{N}$ ratio and $(\mathbf{d}, \mathbf{h}) \delta^{13} \mathrm{C}$ distributions under forest, jungle rubber, rubber and oil palm plantations in (a-d) Harapan and (e-h) Bukit regions. Values at fixed depths were recalculated from the original sampling points, except for Ah horizons. Ah horizon depth fixed at $1 \mathrm{~cm}$ for presentation purpose. Values represent means $\pm \mathrm{SE}(\mathrm{n}=4)$.

Carbon stocks losses in Harapan in the 0-10 cm layer showed the same decrease pattern as the $\mathrm{C}$ content (Table 3-2). C stocks decreased by $24 \%$ under jungle rubber, by $40 \%$ under rubber and by $42 \%$ under oil palm plantations compared to the forest. The $\mathrm{C}$ stock reduction in plantations 
was significant down to $30 \mathrm{~cm}$ depth, but not when deeper layers were included. The mean decrease was $10.1 \pm 2.9 \mathrm{Mg} \mathrm{C} \mathrm{ha}^{-1}$ of $\mathrm{C}$ between plantations and forest in the $0-30 \mathrm{~cm} \mathrm{depth}$. In Bukit, however, there were no significant differences in $\mathrm{C}$ stocks in the top 10 or $30 \mathrm{~cm}$ between land-use types. Plantations had much higher $\mathrm{C}$ stocks in the top $30 \mathrm{~cm}$ in Bukit $(64.0 \pm 4.4 \mathrm{Mg} \mathrm{C}$ $\left.\mathrm{ha}^{-1}\right)$ than in Harapan $\left(44.2 \pm 1.6 \mathrm{Mg} \mathrm{C} \mathrm{ha}^{-1}\right)$. This relation reflected both the higher SOC losses after conversion of forest to plantations in Harapan and the higher $\mathrm{C}$ content in the Bukit subsoil.

Table 3-2. Carbon stocks (Mg C ha' ${ }^{-1}$ ) in four land-use types of Harapan and Bukit regions.

\begin{tabular}{|c|c|c|c|c|}
\hline \multirow[b]{2}{*}{ Land use } & \multicolumn{2}{|c|}{ Harapan } & \multicolumn{2}{|c|}{ Bukit } \\
\hline & $0-10 \mathrm{~cm}$ & $0-30 \mathrm{~cm}$ & $0-10 \mathrm{~cm}$ & $0-30 \mathrm{~cm}$ \\
\hline Jungle rubber & $27.1(3.3)^{1}$ & $47.0(3.5)$ & $33.2(7.0)$ & $71.9(7.0)$ \\
\hline Oil palm & $20.7(2.7)$ & $41.3(3.1)$ & $27.3(3.6)$ & $53.8(7.9)$ \\
\hline Rubber & $21.6(1.6)$ & $44.4(1.2)$ & $41.2(4.9)$ & $81.1(14.9)$ \\
\hline Plantations $^{2}$ & $23.1(1.6) a^{3}$ & $44.2(1.6) a$ & $31.5(2.8) a$ & $64.0(4.4) a$ \\
\hline Forest & $35.8(3.0) b$ & $54.3(4.3) b$ & $34.0(4.4) a$ & $62.0(1.8) a$ \\
\hline
\end{tabular}

Delta ${ }^{13} \mathrm{C}$ and $\mathrm{C} / \mathrm{N}$ ratio in the Ah horizon

In Harapan, the $\mathrm{C} / \mathrm{N}$ ratio was significantly lower and $\delta^{13} \mathrm{C}$ significantly higher in the Ah horizon under the plantations versus forest, indicating that SOC was more intensively decomposed in the topsoil of the plantations (Fig. 3-9). Harapan plantations showed higher $\delta^{13} \mathrm{C}$ values in the Ah horizon compared to forest: up to $2.0 \pm 0.2 \%$ in oil palm plantations (Fig. 3-9). The maximum difference in $\delta^{13} \mathrm{C}\left(\Delta^{13} \mathrm{C}\right)$ between the soils under forest and plantations was much higher in $\mathrm{Ah}$ horizons than in the litter horizons $(0.7 \%$ ) directly in contact with the Ah horizons (OF for forest, jungle rubber and oil palm; OL for rubber). 
Delta ${ }^{13} \mathrm{C}$ and $\mathrm{C} / \mathrm{N}$ ratio in the soil profile

The $\mathrm{C} / \mathrm{N}$ ratios of the plantations were stable with soil depth and slightly higher than those in the forest subsoils (Fig. 3-9). Nevertheless, only jungle rubber showed a significant increase of the $\mathrm{C} / \mathrm{N}$ ratio at $55 \mathrm{~cm}$ compared to other land use types. In contrast to Harapan, $\mathrm{C} / \mathrm{N}$ ratios in Bukit region were not significantly different between forest and plantations in the Ah horizon (Fig. 39). The $\delta^{13} \mathrm{C}$ distribution with depth in soils of Harapan plantations showed two patterns depending on land use (Fig. 3-9). 1) The $\delta^{13} \mathrm{C}$ values in the topsoil under jungle rubber were higher than under the forest. The $\delta^{13} \mathrm{C}$ values, however, were similar in the subsoil below $35 \mathrm{~cm}$ depth. 2) The $\delta^{13} \mathrm{C}$ values below $35 \mathrm{~cm}$ depth under rubber and oil palm plantations experienced a constant shift ( 0.4 to $0.5 \%$ ) compared to the forest. Such pattern could not be identified in Bukit region because $\delta^{13} \mathrm{C}$ distribution with depth under the forest reached a maximum at $35 \mathrm{~cm}$ and decreased at $55 \mathrm{~cm}$ depth.

Regression of the $C$ content and $\delta^{13} C$ with soil depth

Table 3-3. Parameters of the fitted power functions of $\mathrm{C}$ content and $\delta^{13} \mathrm{C}$ with depth in forest soils of Harapan and Bukit regions.

\begin{tabular}{|c|c|c|c|c|c|c|}
\hline \multirow[b]{2}{*}{ Sites } & \multicolumn{3}{|c|}{$\mathrm{C}$ content } & \multicolumn{3}{|c|}{$\delta^{13} \mathrm{C}$} \\
\hline & C(Ah) $)^{1}$ & $\mathbf{k}^{2}$ & $\mathbf{R}^{2}$ & $\delta^{\mathbf{1 3}} \mathbf{C}(\mathbf{A h})^{1}$ & $1^{2}$ & $\mathbf{R}^{2}$ \\
\hline $\mathrm{HF}^{3}$ & 8.51 & $-0.81(.01)^{4}$ & 0.99 & -29.8 & $-0.032(.001)$ & 0.98 \\
\hline HF2 & 5.30 & $-0.76(.01)$ & 0.99 & -29.6 & $-0.029(.001)$ & 0.92 \\
\hline HF3 & 7.57 & $-0.78(.01)$ & 0.97 & -30.0 & $-0.031(.000)$ & 0.98 \\
\hline HF4 & 5.71 & $-0.67(.01)$ & 0.97 & -29.2 & $-0.029(.001)$ & 0.92 \\
\hline BF1 & 6.39 & $-0.51(.01)$ & 0.96 & -28.8 & $-0.025(.001)$ & 0.46 \\
\hline BF2 & 9.02 & $-0.52(.02)$ & 0.81 & -28.7 & $-0.026(.003)$ & 0.00 \\
\hline $\mathrm{BF} 3$ & 6.09 & $-0.61(.02)$ & 0.95 & -29.7 & $-0.031(.000)$ & 0.98 \\
\hline BF4 & 6.79 & $-0.63(.03)$ & 0.95 & -29.4 & $-0.030(.003)$ & 0.81 \\
\hline Harapan & $6.77(.76)$ & $-0.76(.01)$ & 0.91 & $-29.7(.2)$ & $-0.031(.001)$ & 0.84 \\
\hline Bukit & 7.07 (.66) & $-0.57(.02)$ & 0.72 & $-29.2(.2)$ & $-0.027(.001)$ & 0.68 \\
\hline
\end{tabular}


The decrease of $\mathrm{C}$ content and the increase in $\delta^{13} \mathrm{C}$ with soil depth under forest were described by power functions (Eq. 3 and 4). The estimated $k$ parameters were more negative in Harapan than in Bukit, indicating less decrease of $\mathrm{C}$ content with depth in Bukit, especially at the forest sites $\mathrm{BF} 1$ and BF2 (Table 3-3). The standard errors on the $k$ parameter were higher and $\mathrm{R}^{2}$ of the model were lower in Bukit than in Harapan region.

The parameter $l$ was similar among the four Harapan forest sites, reflecting a low dependency of the $\delta^{13} \mathrm{C}$ increase on site-specific conditions. The model showed high $\mathrm{R}^{2}(>0.92)$ and low SE. Furthermore, the regression model including all subsoil samples of the four forest replicates still showed high $\mathrm{R}^{2}$ (> 0.84). Contrastingly, the forest sites in Bukit were separated in two groups. The forest sites BF3 and BF4 showed an increase of the $\delta^{13} \mathrm{C}$ value with depth similar to that in Harapan, with high $\mathrm{R}^{2}$ (> 0.81). However, the model did not fit the sites BF2 and BF3 $\left(\mathrm{R}^{2}<\right.$ 0.46) well. These two sites had lower $\delta^{13} \mathrm{C}$ value in Ah horizons than the other forest soils, and the $\delta^{13} \mathrm{C}$ values did not increase in the subsoil after a strong increase from 0 to $10 \mathrm{~cm}$.

\section{Erosion}

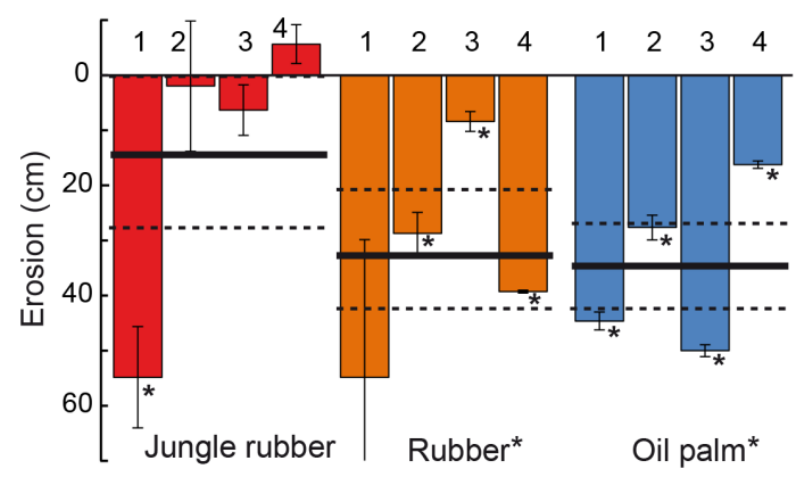

Figure 3-10: Soil erosion in the four replicate soils under jungle rubber, rubber and oil palm plantations in Harapan region.

Bars represent means \pm SE of the erosion calculated for each samples of one soil $(n=3$; except for rubber 1 and 4 , $\mathrm{n}=2$ ). Horizontal lines represent the mean (solid) $\pm \mathrm{SE}$ (dashed) in the corresponding land-use type. Asterisks show significant differences to zero for sites ( $t$-test; $n=3$, except for rubber 1 and $4: n=2$ ) and for land uses ( $t$-test; $n=4)$.

We applied the power function describing the increase of $\delta^{13} \mathrm{C}$ with depth to estimate the erosion (Eq. 4) and used the mean $\delta^{13} \mathrm{C}$ values of the Ah horizons under the forest and the parameters $l$ fitted with all subsoil samples of the four forest soils in Harapan. Calculation of erosion in Bukit, however, was not possible by this approach because: 1) there was no constant shift in $\delta^{13} \mathrm{C}$ between the subsoil under any tree plantations and the subsoil under forest in Bukit. 2) The forest 
replicate sites were not homogenous in term of $\delta^{13} \mathrm{C}$ of $\mathrm{Ah}$ and $\delta^{13} \mathrm{C}$ increase with soil depth. Finally, two forest sites showed a poor fit of the power function.

The estimated erosion after conversion in Harapan region was higher in oil palm $(35 \pm 8 \mathrm{~cm})$ and rubber $(33 \pm 10 \mathrm{~cm})$ plantations than in jungle rubber $(14 \pm 14 \mathrm{~cm})$ (Fig. 3-10). The erosion estimates for the land-use type were significantly different from 0 under rubber and oil palm plantations but not under jungle rubber. The standard errors for all soils other than HR1 under intensive land uses were lower than $4 \mathrm{~cm}$, reflecting the good applicability of the $\delta^{13} \mathrm{C}$ approach. Based on the $\delta^{13} \mathrm{C}$ changes between soils under forest and plantations, we conclude that significant erosion occurred under the intensive plantations in the Harapan region.

\section{Beta values and SOC turnover}

The linear regression of $\delta^{13} \mathrm{C}$ with the log-transformed $\mathrm{C}$ content showed a similar increase of $\delta^{13} \mathrm{C}$ (per tenfold $\mathrm{C}$ content decrease) in the four Harapan forest soils. $\mathrm{R}^{2}$ were high (>0.96) (Fig. 3-11). The slopes of the regressions ( $\beta$ values) and the associated $\mathrm{R}^{2}$ were only minimally modified when the regressions included the Ah horizons $(-2.64 \pm 0.04)$ or not $(-2.82 \pm 0.20)$ (Table $3)$. This indicated a constant increase of $\delta^{13} \mathrm{C}$ with SOC decrease along the whole soil profile in the Harapan forest sites. In contrast, this relationship was not similar at each Bukit forest site. Although $\beta$, calculated on the whole soil profile, varied little among soils (2.98 \pm 0.05$)$. One forest site only showed a constant increase of $\delta^{13} \mathrm{C}$ with the $\mathrm{C}$ content decrease through the whole soil profile.

Table 3-4. Average parameters of the linear regression of $\delta^{13} \mathrm{C}$ with the log-transformed $\mathrm{C}$ content per land-use type in Harapan region.

\begin{tabular}{|c|c|c|c|c|c|c|}
\hline \multirow[b]{2}{*}{ land use } & \multicolumn{3}{|c|}{ whole soil } & \multicolumn{3}{|c|}{ subsoil $^{2}$} \\
\hline & $\boldsymbol{\beta}$ & intercept & $\mathbf{R}^{2}$ & $\boldsymbol{\beta}$ & intercept & $\mathbf{R}^{2}$ \\
\hline Forest & $-2.67(.04)^{1}$ & $-27.46(.18)$ & $>0.97$ & $-2.82(.20)$ & $-27.53(.15)$ & $>0.94$ \\
\hline Jungle rubber & $-2.29(.15)$ & $-26.67(.21)$ & $>0.97$ & $-2.27(.37)$ & $-26.68(.27)$ & $>0.59$ \\
\hline Oil palm & $-3.12(.12)$ & $-26.89(.23)$ & $>0.93$ & $-1.93(.11)$ & $-26.51(.13)$ & $>0.93$ \\
\hline Rubber $^{3}$ & $-2.69(.31)$ & $-26.55(.15)$ & $>0.96$ & $-2.82(.20)$ & $-26.62(.22)$ & $>0.97$ \\
\hline
\end{tabular}

1 Average parameter values and minimum $\mathrm{R}^{2}$ of the four replicates of each land-use type. Values represent means (SE). 2 All samples included except the Ah horizon. 3 For subsoil, slopes and intercepts of the site 1 and 4 under rubber were not estimated by regression because only two subsoil samples were collected. 
In Harapan region, $\beta$ values were similar under rubber $(-2.69 \pm 0.31)$ and under forests, but slightly lower under jungle rubber $(-2.29 \pm 0.15)$ and slightly higher under oil palm plantations ($3.12 \pm 0.12)$. Nevertheless, the differences between the four land-use types were not significant. Interestingly, oil palm plantations showed a SOC shift to lower C content in the Ah horizon according to the regression line of their subsoil (Fig. 3-11). This shift was not observed in any other land-use type in Harapan but occurred in the four oil palm sites. Therefore, this pattern seemed to be a characteristic of oil palm plantations in Harapan region.
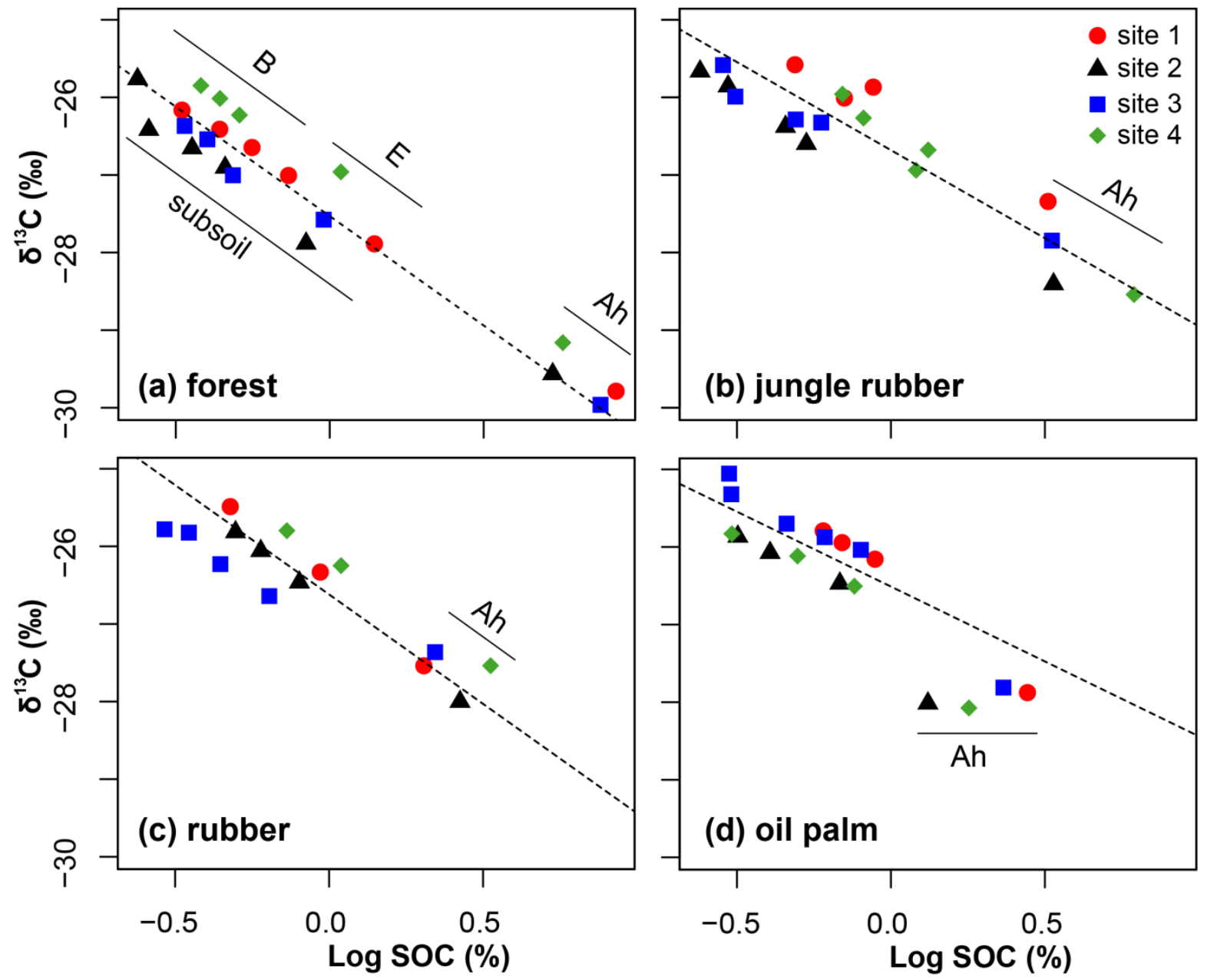

Figure 3-11: Relation between $\delta^{13} \mathrm{C}$ and the logarithm of $\mathrm{C}$ content.

Four replicate sites under (a) forest, (b) jungle rubber, (c) rubber and (d) oil palm plantations in Harapan region. Dashed lines represent the mean linear regression associated with the subsoil of the four replicate sites of the corresponding land-use type. 


\section{Discussion}

\section{SOC losses}

Forest conversion to tree plantations leads to decreases of SOC and SON in the topsoil of the studied regions (Fig. 3-8). The $\mathrm{C}$ content decrease in Ah horizons observed under oil palm and rubber plantations of Harapan region are in the same range as the decrease reported in the top 10 $\mathrm{cm}$ of soils under similar plantations in Ghana (Chiti et al., 2014). They recorded a decrease of C content from about $5 \% \mathrm{C}$ in primary forest to about $2 \%$ under oil palm and rubber plantations in Oxisols developed on various parent materials. They observed significant $\mathrm{C}$ losses also mainly down to $30 \mathrm{~cm}$. The similar $\mathrm{C}$ and $\mathrm{N}$ contents in the subsoil of forest and plantations confirm our hypothesis that the subsoil was not affected up to two decades after conversion (Fig. 3-9).

The magnitude of losses in the topsoil depended on the region. We explain the lower SOC losses in Bukit versus Harapan by the higher clay content in Bukit soils and the presence of smectite in soils such as BF1 and BF2. Indeed, clays were shown to reduce $\mathrm{C}$ losses after forest conversion (Lopez-Ulloa et al., 2005; Powers et al., 2011). The difference in clay content also explains the lesser decrease of $\mathrm{C}$ with depth in Bukit subsoil. Indeed, SOC stocks are positively correlated with clay content (van Noordwijk et al., 1997; McGrath et al., 2001) because clays protect SOM from decomposition by increasing the spatial inaccessibility of SOM within soil aggregates and the interaction with mineral surfaces (Luetzow et al., 2006; Gunina and Kuzyakov, 2014).

The effect of land-use change also depends on the time after conversion. Chiti et al. (2014) measured higher mean annual SOC losses in younger versus older rubber and oil palm plantations. Plantation age cannot explain the higher $\mathrm{C}$ content in the topsoil in Bukit because the oil palm plantations were of about the same age in both regions. Nonetheless, age might be the reason for the more similar $\mathrm{C}$ content in the topsoil of rubber plantations and jungle rubber compared to oil palm plantations in Bukit (Fig. 3-8). The rubber plantations in Bukit were ten years old; four years younger than oil palm plantations. Nevertheless, (de Blécourt et al., 2013) showed that $80 \%$ of the SOC losses took place within the first 5 years and that a steady-state was reached after 20 years in rubber plantations in South China. Therefore, we expect that most of the SOC losses resulting from conversion of forest have already occurred in the rubber plantations. Still, further significant SOC losses by erosion are possible. 
Extensive land use such as jungle rubber led to lesser SOC losses than intensive oil palm and rubber plantations. Nonetheless, the magnitude of the decrease and the effect of land-use intensity depend on the region and, most likely, on soil texture. Consequently, the variability of SOC losses after forest conversion should be evaluated at the regional scale and for specific land uses in order to estimate the ecosystem $\mathrm{C}$ fluxes arising from land-use changes.

\section{Processes involved in SOC decrease by land-use changes}

The vertical distributions of $\mathrm{C}$ content and $\delta^{13} \mathrm{C}$ followed a power function with soil depth and a linear function with the log-transformed C content in Harapan and, to a lesser extent, in Bukit. Because the effect of land-use type was lower and the variability among soils was higher in Bukit, Harapan region was more appropriate to investigate the mechanisms involved in SOC losses after forest conversion.

Two processes potentially contribute to the decrease of $\mathrm{C}$ content and stocks in soil due to landuse change: 1) erosion of the SOC-rich top layer and 2) a stronger decomposition of the SOC after land-use change. The first process - erosion - was estimated based on the vertical distribution of $\delta^{13} \mathrm{C}$ in the soil profile (Fig. 3-9). The second process - SOC decomposition - was assessed considering the increase of $\delta^{13} \mathrm{C}$ as related to the decrease of SOC with depth (Fig. 3$11)$.

\section{Erosion}

The estimated erosion was very high under intensive plantations: up to $35 \pm 8 \mathrm{~cm}$ under oil palm for the 15-years period (Fig. 3-10). The erosion rates for Ferralsols under oil palm and rubber plantations in Malaysia were highly dependent on plantation age, ranging from 4.7 to $9.9 \mathrm{~cm} \mathrm{y}^{-1}$ on newly-cleared land and dropping in mature plantations $\left(0.35\right.$ to $1.56 \mathrm{~cm} \mathrm{y}^{-1}$ ) (Gharibreza et $a l ., 2013)$. To evaluate the plausibility of the erosion assessed by $\delta^{13} \mathrm{C}$, we calculated the erosion rate on cleared land using the RUSLE equation (Renard et al., 1996) and parameters taken from the literature. The calculated rates were of the same order of magnitude as reported in Gharibreza et al. (2013). The rainfall erosivity in the tropics is very high (Yu et al., 2001; Oliveira et al., 2013) due to intensive rains, leading to high erosion of unprotected soil. Unlike rubber and oil palm plantations, jungle rubber plantations are usually established without completely clearing the protective layers (canopy and litter horizons). This explains the absence of erosion in three 
out of four jungle rubber plots. The high erosion in the fourth plot might be explained by a different plantation establishment. These results underline the negative role of deforestation and plantation establishment regarding erosion. This calls for strongly improving management practices to reduce erosion rates especially in the first years of plantation establishment. Although canopy cover increases with plantation maturation, erosion continues due to the sparse or absent ground cover. The exposed roots at the base of the oil palm trunks provide additional clear evidence for post-establishment erosion. In summary, erosion led to SOC losses in oil palm and rubber plantations but not in jungle rubber. Therefore, decomposition is expected to be the main process of SOC losses under jungle rubber.

We rejected the hypothesis that the $\delta^{13} \mathrm{C}$ shift to higher values in plantation versus forest subsoils was a consequence of increased mineralization for two reasons. Firstly, increased SOM mineralization is unlikely to enrich $\delta^{13} \mathrm{C}$ up to $0.5 \%$ in rubber and oil palm plantation compared to forest during just 15-20 years. For instance, the $\delta^{13} \mathrm{C}$ increase of $0.4 \%$ under oil palm at $55 \mathrm{~cm}$ corresponds to a decrease of $\mathrm{C}$ content by $1 / 3$ according to the linear regression between $\delta^{13} \mathrm{C}$ and $\operatorname{logSOC}$ in forest soils (Table 3-4). Secondly, erosion and decomposition affect the depth distribution of the $\delta^{13} \mathrm{C}$, the $\mathrm{C}$ content and the $\mathrm{C} / \mathrm{N}$ ratio in two different ways: 1) stronger decomposition leads to higher $\delta^{13} \mathrm{C}$ values, lower $\mathrm{C}$ contents and lower $\mathrm{C} / \mathrm{N}$ ratios. Graphically, this can be represented as a horizontal shift of the profiles of $\delta^{13} \mathrm{C}, \mathrm{C}$ content and $\mathrm{C} / \mathrm{N}$ ratio under plantations compared to forest (Fig. 3-7). The extent of this shift is not necessarily the same for each depth and for the 3 parameters. (2) Erosion leads to a vertical shift of the same extent of all soil parameters closer to the surface (Fig. 3-7). If significant SOM decomposition had occurred in the subsoil after forest conversion, we would have observed a horizontal shift of $\mathrm{C}$ content and $\mathrm{C} / \mathrm{N}$ ratio to lower values in the subsoil under plantations versus that under forest, which was not the case.

Since erosion leads to a vertical shift of the same extend for all soil parameters (Fig. 3-7), theoretically the erosion could be estimated using any parameter (e.g. $\mathrm{C}$ content, $\mathrm{C} / \mathrm{N}$ ratio) showing a clear trend with depth. However, except for $\delta^{13} \mathrm{C}$, other parameters varied little with depth in Harapan subsoil; i.e. the distribution with depth was almost linear and vertical. Consequently, the vertical shift caused by erosion did not significantly affect the distribution of $\mathrm{C}$ content and $\mathrm{C} / \mathrm{N}$ ratio in plantation subsoils. In conclusion, the $\delta^{13} \mathrm{C}$ distribution is a time- and 
cost-efficient way to measure erosion when a reference site is available and when $\delta^{13} \mathrm{C}$ increases with soil depth. However, the precision of the estimation need to be assessed by direct measurements of erosion.

\section{Decomposition}

The $\beta$ values of soil under forest fall in the middle range of $\beta$ values $(-3.80$ to -1.39$)$ measured in northern Costa Rica (Powers \& Schlesinger, 2002). The forest conversion did not significantly modify the $\beta$ values calculated over the whole depth. This result was expected because decreases in SOC and the $\mathrm{C} / \mathrm{N}$ ratio after forest conversion were observed only in the Ah horizons of the plantations. As a consequence, forest conversion affects the linearity of the regression between $\delta^{13} \mathrm{C}$ and log-transformed $\mathrm{C}$ content rather than the slope ( $\beta$ value).

Under jungle rubber and rubber plantations, the SOC decrease in the Ah horizons after forest conversion and the SOC decrease with depth before conversion (reflected in the subsoil) led to a similar ${ }^{13} \mathrm{C}$ enrichment of SOC (Fig. 3-11). Neither the strong soil erosion in rubber plantations nor the SOC decomposition after forest conversion to jungle rubber plantations modified the ${ }^{13} \mathrm{C}$ enrichment as the SOC decreased. On one hand, erosion was not expected to modify the $\beta$ values, but merly to remove the part of the regression line for the soil layer lost by erosion (Wynn et al., 2006). On the other hand, a change in turnover rates in the Ah horizon would modify the ${ }^{13} \mathrm{C}$ enrichment of SOC because $\beta$ values are correlated with SOC turnover (Garten Jr et al., 2000; Powers \& Schlesinger, 2002; Garten Jr., 2006; Wynn et al., 2006; Campbell et al., 2009). The model developed by Acton et al. (2013) showed that $\beta$ values were dependent on SOC decomposition rates. Accordingly, SOC turnover and decomposition rates in the Ah horizon were not modified by the forest conversion to jungle rubber (Fig. 3-11). SOC losses due to SOC decomposition should therefore be a consequence of reduced $\mathrm{C}$ input from litter. Consequently, $\mathrm{C}$ stocks under jungle rubber should reach a new steady-state depending on the decrease of $\mathrm{C}$ input after forest conversion.

Ah horizons in oil palm plantations unlike rubber and jungle rubber plantations show a shift to lower $\mathrm{C}$ content according to the regression in their subsoil (Fig. 3-11). This indicates that the turnover and decomposition rates in the Ah horizon decreased after forest conversion to oil palms (Fig. 3-12). The SOC remaining after decomposition of the labile pools therefore has 
much slower turnover rates. Indeed, there was no litter deposition and our samples were taken more than four meters away from the trees, where the belowground $\mathrm{C}$ input by roots was low. The old ${ }^{13} \mathrm{C}$-enriched and refractory SOC that was stabilized in deeper horizons before forest conversion is the only remaining pool. The turnover should continue to decrease in the future because of the strongly reduced C input and the decline in SOC quality.

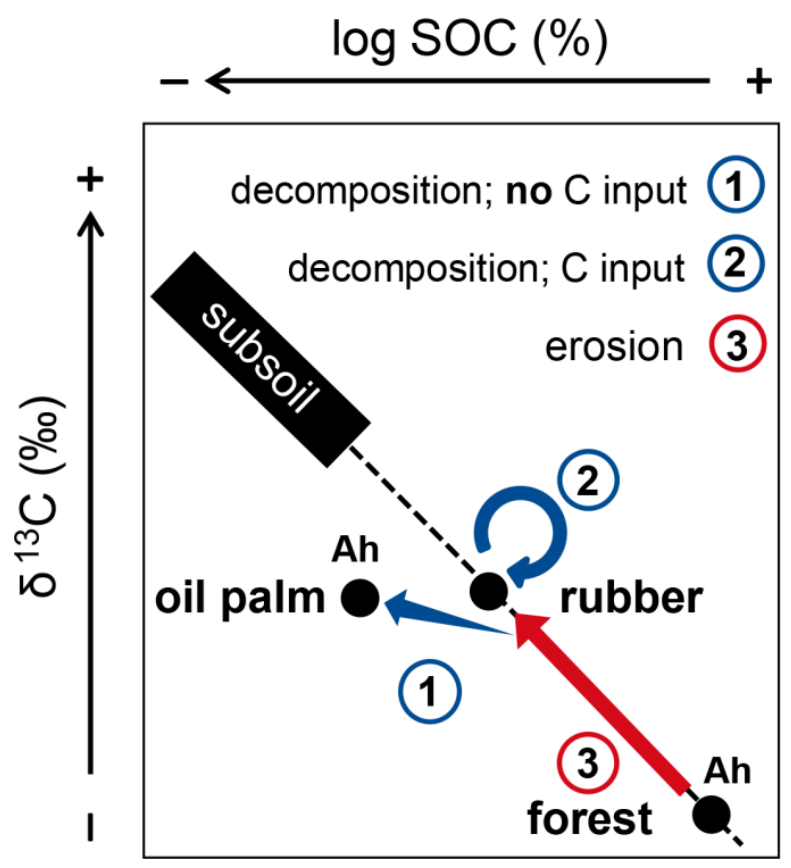

Figure 3-12: Effect of erosion and decomposition on the $\mathrm{C}$ content and the $\delta^{13} \mathrm{C}$ of the Ah horizons under rubber and oil palm plantations, depending on the $\mathrm{C}$ input from leaf litter.

SOC in the Ah horizon under rubber plantations is potentially a mixture of two SOC pools: 1) the old ${ }^{13} \mathrm{C}$-enriched refractory SOC stabilized in deeper horizons before forest conversion and 2) the fresh ${ }^{13} \mathrm{C}$-depleted $\mathrm{C}$ from the litter deposition. The mixing of both pools would shift the isotopic composition of the Ah horizon to lower $\delta^{13} \mathrm{C}$ values (Wynn et al., 2006). Accordingly, the absence of a $\delta^{13} \mathrm{C}$ shift in the Ah horizon under rubber plantations (Fig. 3-11) implies that the pool of old ${ }^{13} \mathrm{C}$-enriched SOC was not substituted by ${ }^{13} \mathrm{C}$-depleted $\mathrm{C}$ from the litter deposition. The most likely explanation is that microorganisms use the easily available litter compounds as their main $\mathrm{C}$ source rather than the old refractory SOC. As a consequence, the new $\mathrm{C}$ from litter is not stabilized in the SOC pool. This indicates that the SOC in the Ah horizon is mainly composed of the SOC sequestrated before the forest conversion and that this pool underwent little modification by decomposition. Nevertheless, this does not exclude the possibility that the 
old SOC is partially substituted with highly decomposed organic compounds from the leaf litter having a similar $\delta^{13} \mathrm{C}$.

Oil palm and intensive rubber plantations have similar impacts regarding SOC losses and erosion. Nonetheless, the decomposition of the old remaining SOC pool under oil palm - but not under rubber plantations - could lead to differences in SOC losses in the long term. SOC in rubber plantation reaches a steady-state after a phase of intensive SOC losses in the first years (de Blécourt et al., 2013). The steady-state of SOC should be reached much later and at a lower $\mathrm{C}$ content in oil palm than in rubber plantations because the old remaining SOC pool is decomposed under oil palms. Consequently, oil palm plantations will continue to lose SOC in the future and the losses might increase drastically by the inevitable renewal of old oil palm plantations every 25 years. Such reestablishment has just started in Jambi province because the older oil palm plantations were established in the early 1990s. We therefore advise 1) to reduce the period without soil protection by planting cover crops at the early stage of the establishment to reduce soil erosion and 2) to leave a maximum of the biomass from the old palm trees on site and/or to keep the land lying fallow for a few years to enable the recovery of SOC pools for the next oil palm generation.

\subsubsection{Acknowledgements}

This study was financed by the Deutsche Forschungsgemeinschaft (DFG) in the framework of the collaborative German - Indonesian research project CRC990. We thank the following persons and organizations for granting us access to and use of their properties: village leaders, local plot owners, PT REKI and Bukit Duabelas National Park. This study was conducted using samples collected based on collection permit No. S.305/KKH-2/2013 recommended by the Indonesian Institute of Sciences (LIPI) and issued by the Ministry of Forestry (PHKA). The CRC990 selected the study sites. We would like to thank the Center for Stable Isotope Research and Analysis of the University of Göttingen for the isotopic analysis, Edzo Veldkamp and Kara Allen for providing the soil bulk density data, Ana Meijide for providing climatic data, Sujai Ahmad for his help in soil description, Anna Jacobs and three reviewers for their useful comments on the manuscript. 


\subsubsection{References}

Abood SA, Lee JSH, Burivalova Z, Garcia-Ulloa J, Koh LP (2014) Relative contributions of the logging, fiber, oil palm, and mining industries to forest loss in Indonesia. Conservation Letters.

Acton P, Fox J, Campbell E, Rowe H, Wilkinson M (2013) Carbon isotopes for estimating soil decomposition and physical mixing in well-drained forest soils. Journal of Geophysical Research: Biogeosciences, 118, 1532-1545.

Balesdent J, Girardin C, Mariotti A (1993) Site-Related $\mathrm{d}^{13} \mathrm{C}$ of Tree Leaves and Soil Organic Matter in a Temperate Forest. Ecology, 74, 1713.

Berhe AA, Harte J, Harden JW, Torn MS (2007) The Significance of the Erosion-induced Terrestrial Carbon Sink. BioScience, 57, 337.

De Blécourt M, Brumme R, Xu J, Corre MD, Veldkamp E (2013) Soil Carbon Stocks Decrease following Conversion of Secondary Forests to Rubber (Hevea brasiliensis) Plantations. PLoS ONE, 8, e69357.

Brüggemann N, Gessler A, Kayler Z et al. (2011) Carbon allocation and carbon isotope fluxes in the plant-soil-atmosphere continuum: a review. Biogeosciences, 8, 3457-3489.

Campbell JE, Fox JF, Davis CM, Rowe HD, Thompson N (2009) Carbon and Nitrogen Isotopic Measurements from Southern Appalachian Soils: Assessing Soil Carbon Sequestration under Climate and Land-Use Variation. Journal of Environmental Engineering, 135, 439448.

Chiti T, Grieco E, Perugini L, Rey A, Valentini R (2014) Effect of the replacement of tropical forests with tree plantations on soil organic carbon levels in the Jomoro district, Ghana. Plant and Soil, 375, 47-59.

Diochon A, Kellman L (2008) Natural abundance measurements of ${ }^{13} \mathrm{C}$ indicate increased deep soil carbon mineralization after forest disturbance. Geophysical Research Letters, 35 , L14402.

Don A, Schumacher J, Freibauer A (2011) Impact of tropical land-use change on soil organic carbon stocks - a meta-analysis. Global Change Biology, 17, 1658-1670. 
Ehleringer JR, Buchmann N, Flanagan LB (2000) Carbon Isotope Ratios in Belowground Carbon Cycle Processes. Ecological Applications, 10, 412-422.

Frazão LA, Paustian K, Pellegrino Cerri CE, Cerri CC (2013) Soil carbon stocks and changes after oil palm introduction in the Brazilian Amazon. GCB Bioenergy, 5, 384-390.

Friedli H, Lotscher H, Oeschger H, Siegenthaler U, Stauffer B (1986) Ice core record of the C13/C-12 ratio of atmosperic $\mathrm{CO}_{2}$ in the past 2 centuries. Nature, 324, 237-238.

Garten Jr. CT (2006) Relationships among forest soil C isotopic composition, partitioning, and turnover times. Canadian Journal of Forest Research, 36, 2157-2167.

Garten Jr CT, Cooper LW, Post III WM, Hanson PJ (2000) Climate controls on forest soil C isotope ratios in the southern Appalachian Mountains. Ecology, 81, 1108-1119.

Gharibreza M, Raj JK, Yusoff I, Othman Z, Tahir WZWM, Ashraf MA (2013) Land use changes and soil redistribution estimation using 137Cs in the tropical Bera Lake catchment, Malaysia. Soil and Tillage Research, 131, 1-10.

Gunina A, Kuzyakov Y (2014) Pathways of litter C by formation of aggregates and SOM density fractions: Implications from ${ }^{13} \mathrm{C}$ natural abundance. Soil Biology and Biochemistry, 71, 95104.

Guo LB, Gifford RM (2002) Soil carbon stocks and land use change: a meta analysis. Global Change Biology, 8, 345-360.

Häring V, Fischer H, Cadisch G, Stahr K (2013) Improved $\delta{ }^{13} \mathrm{C}$ method to assess soil organic carbon dynamics on sites affected by soil erosion. European Journal of Soil Science, $\mathbf{6 4}$, 639-650.

Hobbie EA, Werner RA (2004) Intramolecular, compound-specific, and bulk carbon isotope patterns in C3 and C4 plants: a review and synthesis. New Phytologist, 161, 371-385.

Islam KR, Weil RR (2000) Land use effects on soil quality in a tropical forest ecosystem of Bangladesh. Agriculture, Ecosystems \& Environment, 79, 9-16.

Lal R (2001) Soil degradation by erosion. Land Degradation \& Development, 12, 519-539. 
Laumonier Y, Uryu Y, Stüwe M, Budiman A, Setiabudi B, Hadian O (2010) Eco-floristic sectors and deforestation threats in Sumatra: identifying new conservation area network priorities for ecosystem-based land use planning. Biodiversity and Conservation, 19, 1153-1174.

Lopez-Ulloa M, Veldkamp E, de Koning GHJ (2005) Soil carbon stabilization in converted tropical pastures and forests depends on soil type. Soil Science Society of America Journal, 69, 1110-1117.

Luetzow M v., Kogel-Knabner I, Ekschmitt K, Matzner E, Guggenberger G, Marschner B, Flessa H (2006) Stabilization of organic matter in temperate soils: mechanisms and their relevance under different soil conditions - a review. European Journal of Soil Science, 57, 426-445.

Margono BA, Potapov PV, Turubanova S, Stolle F, Hansen MC (2014) Primary forest cover loss in Indonesia over 2000-2012. Nature Climate Change, NCLIMATE2277.

Mariotti A, Germon JC, Hubert P, Kaiser P, Letolle R, Tardieux A, Tardieux P (1981) Experimental determination of nitrogen kinetic isotope fractionation: some principles; illustration for the denitrification and nitrification processes. Plant and soil, 62, 413-430.

McGrath DA, Smith CK, Gholz HL, Oliveira F de A (2001) Effects of Land-Use Change on Soil Nutrient Dynamics in Amazonia. Ecosystems, 4, 625-645.

Natelhoffer KJ, Fry B (1988) Controls on Natural Nitrogen-15 and Carbon-13 Abundances in Forest Soil Organic Matter. Soil Science Society of America Journal, 52, 1633-1640.

Van Noordwijk M, Cerri C, Woomer PL, Nugroho K, Bernoux M (1997) Soil carbon dynamics in the humid tropical forest zone. Geoderma, 79, 187-225.

Oliveira PTS, Wendland E, Nearing MA (2013) Rainfall erosivity in Brazil: A review. CATENA, 100, 139-147.

Powers JS (2004) Changes in Soil Carbon and Nitrogen after Contrasting Land-use Transitions in Northeastern Costa Rica. Ecosystems, 7, 134-146.

Powers JS, Schlesinger WH (2002) Geographic and vertical patterns of stable carbon isotopes in tropical rain forest soils of Costa Rica. Geoderma, 109, 141-160. 
Powers JS, Corre MD, Twine TE, Veldkamp E (2011) Geographic bias of field observations of soil carbon stocks with tropical land-use changes precludes spatial extrapolation. Proceedings of the National Academy of Sciences, 108, 6318-6322.

Renard KG, Foster GR, Weesies GA, McCool DK, Yoder DC (1996) Predicting soil erosion by water: a guide to conservation planning with Revised Universal Soil Loss Equation (RUSLE). U.S. Department of Agriculture, Agriculture Handbook No. 703.

Ross SM (1993) Organic matter in tropical soils: current conditions, concerns and prospects for conservation. Progress in Physical Geography, 17, 265-305.

Ross SM, Dykes A (1996) Soil conditions, erosion and nutrient loss on steep slopes under mixed dipterocarp forest in Brunei Darussalam. In: Tropical Rainforest Research - Current Issues, Vol. 74 (eds Edwards DS, Booth WE, Choy SC), pp. 259-270. Springer Netherlands.

Schroth G, D'Angelo SA, Teixeira WG, Haag D, Lieberei R (2002) Conversion of secondary forest into agroforestry and monoculture plantations in Amazonia: consequences for biomass, litter and soil carbon stocks after 7 years. Forest Ecology and Management, 163, $131-150$.

Sidle RC, Ziegler AD, Negishi JN, Nik AR, Siew R, Turkelboom F (2006) Erosion processes in steep terrain - Truths, myths, and uncertainties related to forest management in Southeast Asia. Forest Ecology and Management, 224, 199-225.

Suess HE (1955) Radiocarbon concentration in modern wood. Science, 122, 415-417.

Trumbore S (2000) Age of Soil Organic Matter and Soil Respiration: Radiocarbon Constraints on Belowground C Dynamics. Ecological Applications, 10, 399.

Werth M, Kuzyakov Y (2010) ${ }^{13} \mathrm{C}$ fractionation at the root-microorganisms-soil interface: A review and outlook for partitioning studies. Soil Biology and Biochemistry, 42, 1372-1384.

Wilcove DS, Koh LP (2010) Addressing the threats to biodiversity from oil-palm agriculture. Biodiversity and Conservation, 19, 999-1007. 
Wynn JG, Bird MI, Wong VNL (2005) Rayleigh distillation and the depth profile of ${ }^{13} \mathrm{C} /{ }^{12} \mathrm{C}$ ratios of soil organic carbon from soils of disparate texture in Iron Range National Park, Far North Queensland, Australia. Geochimica et Cosmochimica Acta, 69, 1961-1973.

Wynn JG, Harden JW, Fries TL (2006) Stable carbon isotope depth profiles and soil organic carbon dynamics in the lower Mississippi Basin. Geoderma, 131, 89-109.

Yu B, Hashim GM, Eusof Z (2001) Estimating the r-factor with limited rainfall data: a case study from peninsular Malaysia. Journal of Soil and Water Conservation, 56, 101-105.

Ziegler AD, Phelps J, Yuen JQ et al. (2012) Carbon outcomes of major land-cover transitions in SE Asia: great uncertainties and REDD+ policy implications. Global Change Biology, 18, 3087-3099. 


\subsection{Study 3}

\section{New approach for sensitivity of soil fertility indicators to land-use changes: Theory and examples from conversion of Indonesian rainforest to plantations}

Thomas Guillaume $^{1 *}$, Deejay Maranguit ${ }^{1}$, Kukuh Murtilaksono ${ }^{2}$, Yakov Kuzyakov ${ }^{1}$

${ }^{1}$ Department of Soil Science of Temperate Ecosystems, and Department of Agricultural Soil Science, Georg-August-University of Göttingen, Germany

${ }^{2}$ Department of Soil Science and Land Resources, Bogor Agricultural University, Indonesia

Status: Under review in Ecological Indicators since 20.08.2015

*Corresponding Author:

Georg-August-University of Göttingen

Department of Soil Science of Temperate Ecosystems

Büsgenweg 2

37077 Göttingen, Germany

Tel. + 495513922061 Fax + 49551393310 ,

email: thoguillaume@gmail.com 


\subsubsection{Abstract}

Tropical forest conversion to agricultural land leads to a strong decrease of soil organic matter (SOM) stocks. While the decrease of the soil $\mathrm{C}$ sequestration function is easily measurable, the impacts of SOM losses on soil fertility remain unclear. Especially the assessment of the sensitivity of other soil fertility indicators as related to ecosystem services suffers from a lack of clear methodology. We develop a new approach to assess the sensitivity soil fertility indicators and test it in a case study involving biological and chemical soil properties affected by rainforest conversion to plantations. The approach is based on (non-)linear regressions between SOM losses and soil fertility indicators standardized to the natural ecosystem. Biological indicators (basal respiration, microbial biomass, acid phosphatase), labile SOM pools (dissolved organic carbon and light fraction) and nutrients (total $\mathrm{N}$ and available $\mathrm{P}$ ) were measured in Ah horizons from rainforests, jungle rubber, rubber (Hevea brasiliensis) and oil palm (Elaeis guineensis) plantations located on Sumatra (Indonesia). The negative impact of land-use changes on all measured indicators increased in the following sequence: forest $<$ jungle rubber $<$ rubber $<$ oil palm. The basal respiration, microbial biomass and nutrients were comparatively resistant to SOM losses, whereas the light fraction losses were stronger than SOM losses. The microbial C use efficiency was not modified by the land use. Therefore, the resistance of the SOM availability for microorganisms to SOM losses suggests that a decrease of SOM quality was partly compensated by litter input and a relative SOM enrichment by nutrients. Nonetheless, the relationship between the basal respiration and SOM was non-linear; i.e. SOM losses at low C content had a strong negative impact on microbial activity. Therefore, a small decrease of $\mathrm{C}$ content under oil palm compared to rubber plantations yielded a strong drop in microbial activity. Consequently, management practices mitigating SOM losses in oil palm plantations would strongly increase soil fertility. We conclude that the new approach enables quantitatively assessing the sensitivity of diverse soil functions to land-use changes and can thus be used to assess resilience of agroecosystems with various use intensities. 


\subsubsection{Introduction}

The increase of agricultural land area in the tropics is ongoing mainly at the expense of primary and secondary forests (Gibbs et al., 2010). While tropical deforestation rates are tending to stabilize or to decrease in regions like Brazil, they are still increasing in Indonesia, driven by the international demand for wood-derived products as well as for agricultural land for oil palm and rubber plantations (Abood et al., 2014; Margono et al., 2014). Forest conversion in general and especially to oil palm and rubber plantations strongly changes ecosystem functioning (Barnes et al., 2014). This results in losses of biodiversity (Barlow et al., 2007), ecosystem services such as water supply (Bruijnzeel, 2004) and C sequestration in the plant biomass and in the soil (Don et al., 2011; Kotowska et al., 2015). Guillaume et al. (2015) observed up to $70 \%$ soil organic carbon (SOC) losses in the topsoil under oil palm and rubber plantations in Indonesia compared to rainforest. Further, SOC losses depended on land-use intensity. Tropical forest conversion to agricultural land also leads to a decrease of biological and chemical indicators of soil fertility (Joergensen, 2010; Kaschuk et al., 2010). Nevertheless, only few studies have included rubber and oil palm plantations, despite the large-scale extension of these land-use types in the last decades (Gatto et al., 2015). In a recent review on the impact of land-use changes on microorganisms in the tropics (Joergensen, 2010), only six studies on rubber and oil palm plantations encompassing two continents were included, and only three of them used forest sites as a baseline to evaluate the plantation's impact.

The decrease of $\mathrm{C}$ sequestrated in soils is a major concern because it represents the biggest terrestrial $\mathrm{C}$ pool and is in exchange with the biological $\mathrm{C}$ cycle and atmospheric $\mathrm{CO}_{2}$. The loss of the $\mathrm{C}$ sequestrating function of soils after forest conversion to plantations is measured straightforwardly by comparing SOC stocks among undisturbed (e.g. forest) and agricultural ecosystems. Soil organic matter (SOM) losses are also associated with a decrease of soil quality and fertility and thus, with a soil's capacity to provide sustainable ecosystem services (Bastida et al., 2008; Lal, 2010, 2006). SOM is considered as an "umbrella" property of soil fertility because SOM decrease is associated with the decrease of most soil properties and functions related to fertility. This includes bulk density, nutrient availability, water penetration and holding capacity, erodibility, and microbial activity (Lal, 2006). For instance, SOM and crop yield are positively correlated in various agricultural systems (Bauer and Black, 1994; Ganzhara, 1998). 
Nevertheless, the effects of SOM losses on soil fertility remain unclear because it is difficult to quantify relationships between soil properties and soil functions (Letey et al., 2003).

Soil fertility cannot be measured directly because the commonly used crop yield reflects only one of many soil functions and services. Therefore, soil fertility is classically assessed by selecting and interpreting changes of soil indicators recognized as important for fertility (Askari and Holden, 2014). Maximal or optimal levels of biological, chemical or physical soil properties are specific for each natural or agricultural system. Consequently, in order to evaluate the impact of land-use changes, soil properties must be compared to a baseline level from undisturbed environments or from specific sustainable management practices (Gil-Sotres et al., 2005). Moreover, various soil properties and functions are not similarly affected by land-use changes. This calls for determining the sensitivity or the resistance of soil properties and processes to land-use changes in order to identify which functions are at risk and to target appropriate management practices. For this purpose, determining the sensitivity of soil properties or processes to SOM losses is especially appropriate because SOM is i) correlated with most soil fertility indicators, ii) easily measurable and iii) directly affected by management practices.

Biological soil properties and SOM labile pools are more sensitive to land-use or management changes than physical or chemical soil properties (Bastida et al., 2008; Raiesi and Beheshti, 2015; Sharma et al., 2011). For instance, microbial biomass, basal respiration, extracellular enzymes activities, SOM light fraction or dissolved organic matter (DOM) decreased generally faster after land-use changes than the total SOM (Bolinder et al., 1999; Kandeler et al., 1999; Powlson et al., 1987; Sparling, 1992). Microbial activity is a main indicators reflecting soil fertility because microorganisms drive all $\mathrm{C}$ and nutrient cycles and depend strongly on SOM content (Anderson and Domsch, 1989). Microbial activity, however, depends not only on the total amount of SOM but also on its availability for microorganisms, e.g. the proportion of labile SOM pools (von Lützow et al., 2006) or the nutrient content (Cleveland et al., 2006). For instance, microbial activities measured based on basal respiration during incubation of free particulate organic matter, the light fraction or the water- or K2SO4-soluble $\mathrm{C}$ were higher than the basal respiration of the bulk soil (Alvarez et al., 1998; Haile-Mariam et al., 2008; Mueller et al., 2014; Wagai et al., 2013; Wang et al., 2003). Thus, the basal respiration reported per unit of SOM is an indicator of SOM availability. Using ratios of single indicators, further indices were 
developed reflecting microbial community functioning or SOM functions in the soil (Anderson, 2003). Among them, the metabolic quotient $\left(\mathrm{qCO}_{2}\right)$ (basal respiration to microbial biomass ratio) is one of the most widely used and reflects the carbon-use efficiency of microbial communities (Anderson and Domsch, 1990). The microbial quotient (microbial biomass to soil SOC ratio) was suggested to reflect the soil function of supporting microbial growth (Insam and Domsch, 1988).

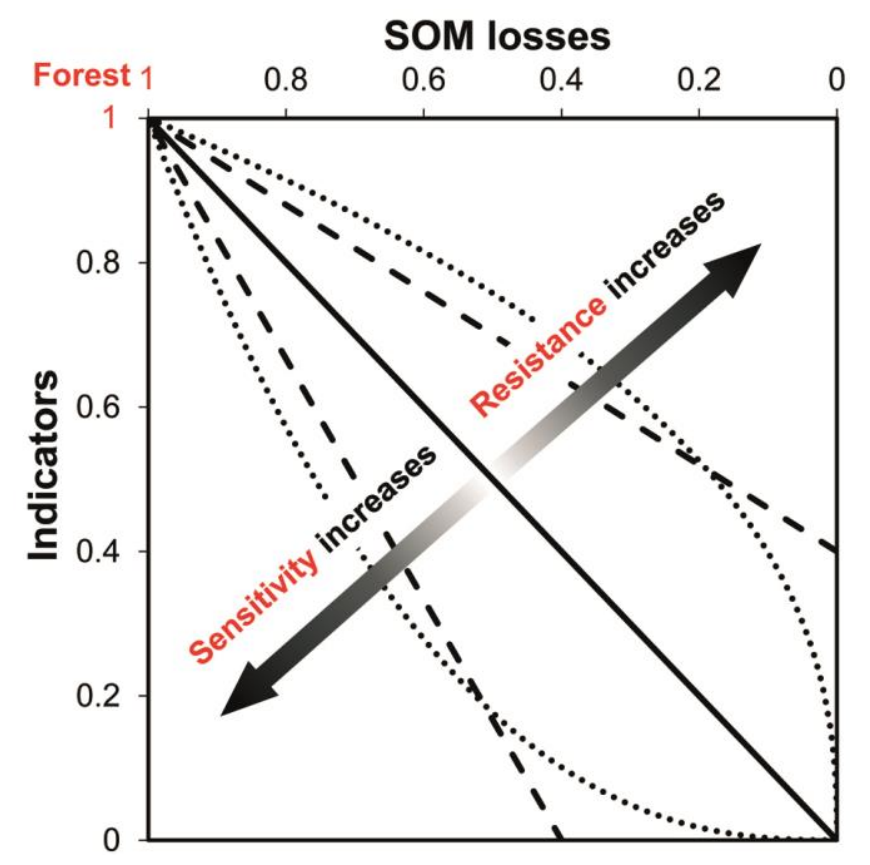

Figure 3-13: Concept of sensitivity of soil fertility indicators to SOC losses (or other main variables) by land-use changes.

Indicators can decrease proportionally with the SOM losses (solid line), or be resistant or sensitive to them. In the latter case, the indicator sensitivity or resistance is either independent of SOM loss intensity (linear relationships; dashed lines) or dependent on SOM loss intensity (non-linear relationships; dotted lines). Note: all indicators are standardized to their average value in an undisturbed ecosystem (here: tropical rainforest).

Sun-ray plots or radar plots provide quick overviews of the sensitivity of all indicators, but do not quantify it (Bloem et al., 2006; Schloter et al., 2003). Changes of indices based on the ratios of two variables after land-use change reflect differences in the sensitivity of these two variables. However, because comparisons are made between groups (land-use types) and not along a continuous and quantitative variable, it is not possible to determine the relationship between these variables. Linear and non-linear relationships among soil properties or functions have completely different ecological meaning and implications for management practices. On the one hand, a linear relationship between the decrease of SOM and of a soil property or function 
implies that SOM losses have the same effect at any SOM content whenever the property or function is sensitive, resistant or proportionally decreases with SOM losses (Fig. 3-13). On the other hand, a non-linear relationship implies that the effect of land-use change depends on the SOM content. In the case of a logarithmic relationship, SOM losses at high SOM content have little impact on the soil property or process. In contrast, small SOM losses at low SOM content have a strong negative impact on the related soil property or process (Fig. 3-13).

We hypothesized that 1) SOM losses in plantations are associated with a strong decrease of soil fertility indicators and SOM availability. Furthermore, 2) the indicators do not necessarily decrease proportionally with SOM losses but could be more resistance or more sensitive than SOM to land-use change (Fig. 3-13). Finally, 3) the indicators' sensitivity varies depending on the SOM loss intensity. Therefore, the study objectives were to 1) quantify the changes in soil fertility indicators following SOM losses after forest conversion to oil palm and rubber plantations 2) relate SOM availability with biological and chemical indicators of soil fertility and 3) provide a comprehensive approach to assess the sensitivity of these (and other) fertility indicators to SOM losses. 


\subsubsection{Materials and Methods}

Study sites

Study sites were located in Jambi Province (Sumatra, Indonesia) under a humid tropical climate $\left(27^{\circ} \mathrm{C} ; 2400 \mathrm{~mm} \mathrm{y}^{-1} ; 112-259 \mathrm{~mm}\right.$ month-1) with a drier season lasting from May to September. The experimental design includes natural lowland tropical rainforest and three land-use types dominating on Sumatra: 1) jungle rubber, 2) rubber plantation and 3) oil palm plantation. Soils were Acrisols with loamy texture. Forest sites were located in Harapan Rainforest, an old-growth forest that was subject to minor logging until 2003, when it became a conservation and restoration area. Jungle rubber corresponds to an agroforest, in which rubber trees are extensively planted in partially logged forest. Rubber and oil palm plantations were smallholding intensive monocultures of ages ranging from 12 to 17 years. Four replicate sites for each landuse type were selected for a total of 16 field sites. Ah horizons of loamy Acrisols were collected in soil pits. A detailed description of sites, sampling and soil parameters was presented earlier (Guillaume et al., 2015). Further information on study sites and land-use history in the study region are available in Barnes et al. (2014) and Gatto et al.(2015).

\section{Chemical analyses}

Total $\mathrm{C}$ and $\mathrm{N}$ contents in soil were measured using an elemental analyser (Eurovector). Available $\mathrm{P}$ was defined as the sum of $\mathrm{P}$ by a two-step extraction method (Hedley et al., 1982). First, the labile inorganic $\mathrm{P}$ that is directly exchangeable with the soil solution was extracted using deionized water. Then, the labile inorganic and organic P sorbed onto mineral surfaces were extracted using $0.5 \mathrm{M} \mathrm{NaHCO}_{3}$ at $\mathrm{pH}$ 8.5. Phosphate concentrations in soil extracts were determined by molybdate colorimetry (Murphy and Riley, 1962) using a calibrated spectrophotometer (Specord 40).

\section{Incubation experiment}

Soil from Ah horizons from the 16 sites were incubated in the dark at room temperature $\left(23 \mathrm{C}^{\circ}\right)$. Six subsamples from each site were incubated. Twenty grams of air-dried and sieved soil were rewetted to $60 \%$ of their water holding capacity and incubated in $250 \mathrm{ml}$ bottles. To determine 
respiration rates, $\mathrm{CO}_{2}$ was continuously trapped within $2 \mathrm{ml}$ of $1.0 \mathrm{M} \mathrm{NaOH}$. Trapped- $\mathrm{CO}_{2}$ was then back-titrated using $0.1 \mathrm{M} \mathrm{HCl}$ against phenolphthalein, after $\mathrm{BaCl}_{2}$ addition to precipitate carbonates.

A two-pool mixed-model was used to describe SOM mineralization kinetics, thereby estimating the basal respiration (Bonde and Lindberg, 1988). The first pool follows a first-order decomposition kinetics, while the second follows a zero-order kinetics, i.e. the decomposition rate is constant over time:

\section{(1) $\operatorname{Cmin}=C_{l}\left(1-\exp ^{-t k_{l}}\right)+B R t$}

where $t$ is the time, $C \min$ is the cumulative $\mathrm{CO}_{2}$ mineralized to time t, $C l$ is the labile $\mathrm{C}$ pool released from sample preparation and re-wetting, $k l$ is the decomposition constant of the labile pool and $B R$ is the basal respiration.

\section{Microbial biomass and DOC}

Microbial biomass (Cmic) was measured by the fumigation-extraction method (Vance et al., 1987). Briefly, $7 \mathrm{~g}$ of incubated samples were fumigated with ethanol-free $\mathrm{CHCl}_{3}$ for $24 \mathrm{~h}$ in an exsiccator. After $\mathrm{CHCl}_{3}$ removal, soluble $\mathrm{C}$ from fumigated and non-fumigated samples was extracted with $30 \mathrm{ml}$ of $0.5 \mathrm{M} \mathrm{K}_{2} \mathrm{SO}_{4}$ by shaking for $1 \mathrm{~h}$ on an orbital shaker $(120 \mathrm{rpm})$. Extracts were filtered and soluble C was measured using a Multi N/C 2100s (Analytik Jena, Germany). The DOC corresponded to the soluble $\mathrm{C}$ extracted by $\mathrm{K}_{2} \mathrm{SO}_{4}$ in the non-fumigated extract. The difference in soluble $\mathrm{C}$ between fumigated and non-fumigated samples was converted to Cmic using a factor of 0.45 . This factor was chosen in order to compare our data with other studies because it is the most widely used (Joergensen, 2010).

\section{Enzyme activities}

Extracellular enzyme activity (EEA) of acid phosphate was measured by fluorimetric microplate assay using fluorogenic methylumbelliferone-based (MU) substrates (Marx et al., 2001). Briefly, $0.5 \mathrm{~g}$ of incubated soil was shaken for $30 \mathrm{~min}$ with sterile water and then dispersed by an ultrasonic disaggregator $\left(50 \mathrm{~J} \mathrm{~s}^{-1}\right.$ for $120 \mathrm{~s}$ ). For each sample, three $50 \mu \mathrm{l}$ aliquots of the stirred suspension were mixed in a 96-well microplate (Brand pureGrade, black) with $50 \mu \mathrm{l}$ buffer 
(MES) and $100 \mu \mathrm{l}$ of substrate solution of increasing concentrations $(0,20,40,60,80,100,200$ and $400 \mu \mathrm{mol}$ substrate). Plates were measured directly after substrate addition and $1 \mathrm{~h}$ later with an automated fluorometric plate-reader (Wallac 1420, Perkin Elmer, Turku, Finland). The phosphatase activity corresponded to the maximal reaction rate (Vmax) estimated by fitting a Michaelis-Menten kinetics function to the reaction rate measured at the increasing substrate concentrations.

\section{Density fractionation}

The density fractionation was a simplification of the method described by John et al. (2005). Four grams of incubated soil were placed in a centrifuge tube with 5 glass beads of $5 \mathrm{~mm}$ diameter and $20 \mathrm{ml}$ of sodium polytungstate solution (SPT; $1.6 \mathrm{~g} \mathrm{~cm}^{-3}$ ). The tube were shaken 16 $\mathrm{h}$ on an orbital shaker $(120 \mathrm{rpm})$ to disperse the free and occluded particulate organic matter. After dispersion, the suspension was centrifuged for $1 \mathrm{~h}$ at $4700 \mathrm{rpm}$. The supernatant composed of free and occluded particulate organic matter was then filtered $(0.45 \mu \mathrm{m})$ using vacuum and washed twice with $100 \mathrm{ml}$ deionized water. The $\mathrm{C}$ and $\mathrm{N}$ contents of the light fraction, composed of free and occluded particulate organic matter, were measured using a $\mathrm{CN}$ elemental analyser (Vario EL cube, Elementar Analysensysteme GmbH, Germany).

\section{Sensitivity of soil fertility indicators}

To compare the sensitivity of soil properties to SOM losses, each variable was standardized to its mean value under rainforest. Thus, values ranging from 0 to $<1$ indicate a decrease compared to the forest sites. If an indicator decreases proportionally with the $\mathrm{C}$ content (e.g. a decrease of $50 \%$ of $\mathrm{C}$ content is associated with a decrease of $50 \%$ of a soil property), then the regression between both variables has a slope of 1 and an intercept of 0 (Fig. 3-13). The data standardization imposes the conditions that $\mathrm{f}(1)=1$; therefore the sensitivity or resistance of the variables can be assessed by linear or power regressions for which only one parameter has to be estimated. The linear regression slope was estimated by the following equation:

(2) $y=a x+1-a$ 
where $y$ is the predicted standardized value of a variable at a C content of $x$, and $a$ the slope of the linear regression, corresponding to the sensitivity of the variable. The intercept (b) can be calculated from the slope $(b=1-a)$. According to the hypothesis that the relation between the decreases of variables and $\mathrm{C}$ content might be non-linear, power function regressions were fitted with the following equation:

(3) $y=x^{a}$

where $y$ is the predicted standardized value of a variable at a $\mathrm{C}$ content of $x$, and $a$ the exponent of the non-linear regression. Equation 3 satisfies the condition $\mathrm{f}(1)=1$ independently of a. However, it also imposes the condition that $\mathrm{f}(0)=0$, i.e. that the variable must reach 0 in the absence of SOM.

The proportionality of the decrease between two variables is assessed if confidence intervals of the estimated slope or exponent include 1. If 1 is excluded, then the indicator is either resistant to SOM losses (slope or exponent $<1$ ) or sensitive to SOM losses (slope or exponent $>1$ ). Finally, the linearity or non-linearity of a variable decrease was assessed by choosing the model with the highest $\mathrm{R}^{2}$ because both models had only one estimated parameter.

\section{Statistics}

All statistical analyses were performed using the open source software R version 3.2.0. Land-use type effect on indicators or indices was tested by analysis of variance (ANOVA) with forest, jungle rubber, rubber and oil palm as fixed factors. For each factor, four independent field sites were used as replicates. Normality of residuals and variance homogeneity were tested with Shapiro-Wilk and a Bartlett test, respectively. Subsequently, a post hoc Tukey HSD test was performed to assess differences between factors. Linear and non-linear regressions were fitted using the function nls (nls2 package). Residuals normality was tested by a Shapiro-Wilk test. The decomposition kinetic model was fitted for each field replicate using the data from the 6 laboratory replicates. Data are presented as mean of four replicates \pm standard error (SE). If not specified, discussed differences are significant at least at a p-value $<0.05$. 


\subsubsection{Results}

\section{SOM decomposition kinetics}

Soil re-wetting led to high respiration rates that stabilized three weeks after water addition. After a time-lag of maximum 3 days, labile organics released by sample preparation and soil rewetting followed first-order decays in all transformation systems. The half-life of the labile pools ranged from $4.5 \pm 0.2$ for forest to $8.6 \pm 0.8$ days for rubber plantations (Table 3-6). After the consumption of the initial labile pool, respiration rates stabilized in all land-use types to a constant basal respiration. Therefore, the decomposition of the pools responsible for the basal respiration had to be fitted with a zero-order kinetics. This indicates that the decomposition rates

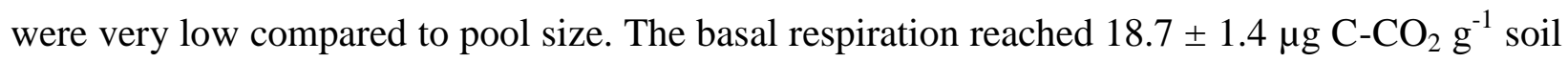
$\mathrm{d}^{-1}$ under forest, but was strongly reduced under plantations; up to $65 \pm 8 \%$ less under oil palm and $48 \pm 10 \%$ less under rubber plantations (Fig. 3-14). The basal respiration under jungle rubber was $33 \pm 10 \%$ lower than under forest. Considering a carbon use efficiency of $50 \%$, the proportion of the SOM processed by microorganisms ranged from $6 \%$ under forest to $9 \%$ under rubber plantations. This corresponds to $20 \%$ of the remaining light fraction under forest and 55 $\%$ under rubber, indicating that most of the light fraction in the soil under all land-use types remained after 70 days of incubation.

\section{Effect of land-use on soil fertility parameters}

All measured biological and chemical indicators of soil fertility decreased in plantations compared to tropical rainforest (Fig. 3-14). Similarly to the SOM losses, the highest values were found under rainforest, and decreased in the following order: rainforest > jungle rubber > rubber $>$ oil palm. Land-use effect was significant for all indicators except for the available $\mathrm{P}(\mathrm{p}<0.09)$. All other indicators were significantly lower under the three plantation types compared to forest (except the basal respiration under jungle rubber, $\mathrm{p}<0.08$ ). While the SOM labile pools (LF and DOC) and acid phosphatases showed no difference among plantations, the plantation type had an effect on the $\mathrm{N}$ content, microbial biomass and basal respiration. Compared to forest, the basal respiration was significantly reduced only under monocultures. The microbial biomass under oil 
palm plantations tended to be lower compared to rubber $(\mathrm{p}<0.07)$ and was significantly lower compared to jungle rubber.

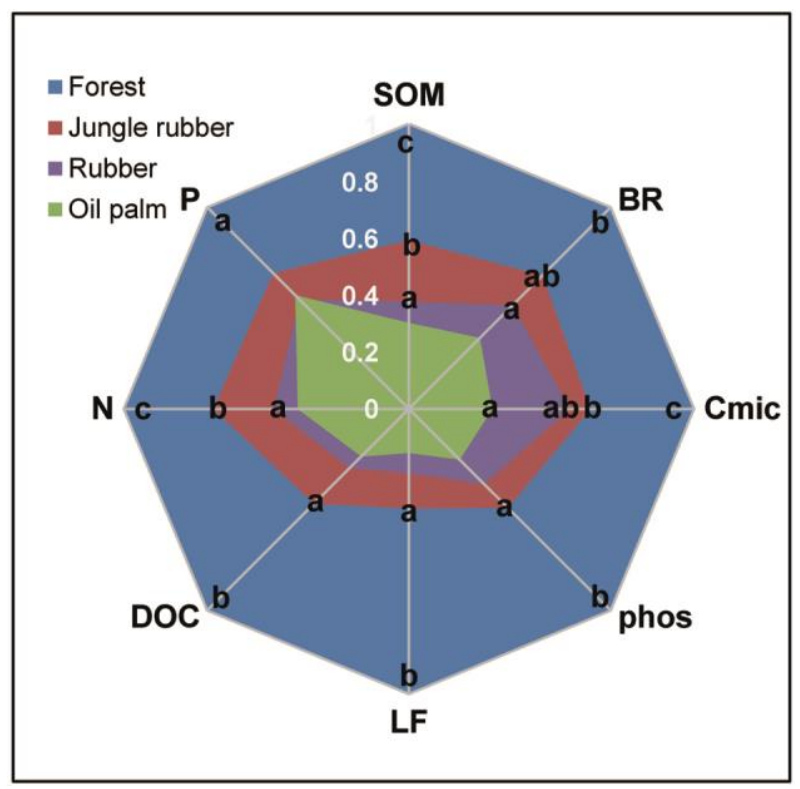

Figure 3-14: Decrease of soil fertility indicators per land-use type

Carbon content (SOM), basal respiration (BR), microbial biomass (Cmic), acid phosphatase (phos), light fraction $(\mathrm{LF}), \mathrm{K}_{2} \mathrm{SO}_{4}$-soluble $\mathrm{C}, \mathrm{N}$ content $(\mathrm{N})$ and available $\mathrm{P}(\mathrm{P})$. The values are standardized to the respective rainforest mean (=1). Different letters represent significant differences of the indicator between land uses ( $\mathrm{n}=4$, except for $\mathrm{P}$ $\mathrm{n}=3$; ANOVA; $\mathrm{p}<0.05$ ). Letter $a$ was not repeated if land-use types with lower values were not significantly different.

The calculated indices reflecting microbial ecological strategies or SOM availability (BasResp/Cmic, BasResp/SOM, Cmic/SOM) showed no clear trends among land-use types (Fig. 3-15). The variability of indices was high within land use, reducing considerably the power of analysis of variance. Especially the microbial community under oil palm showed the lowest and the highest BasResp/Cmic and Cmic/SOM ratios measured in any land-use type. By excluding oil palm from the analysis, $\mathrm{Cmic/SOM}$ was the only index showing a significant effect of land use. Rubber plantations had higher $\mathrm{Cmic} / \mathrm{SOM}$ ratios compared to jungle rubber and forest sites, indicating an increase of the SOM availability and, consequently, better conditions for microbial growth under rubber plantations. 
3 Publications and Manuscripts: Study 3

Table 3-5. Soil properties and processes under forest, extensive rubber plantations (jungle rubber), rubber and oil palm monocultures.

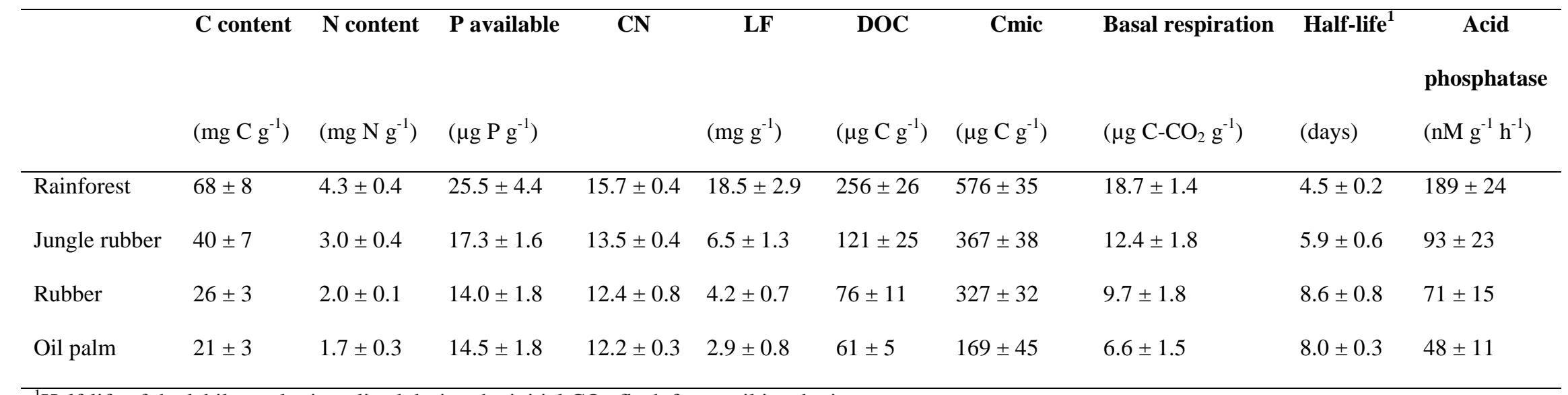

${ }^{1}$ Half-life of the labile pool mineralized during the initial $\mathrm{CO}_{2}$-flush from soil incubation 


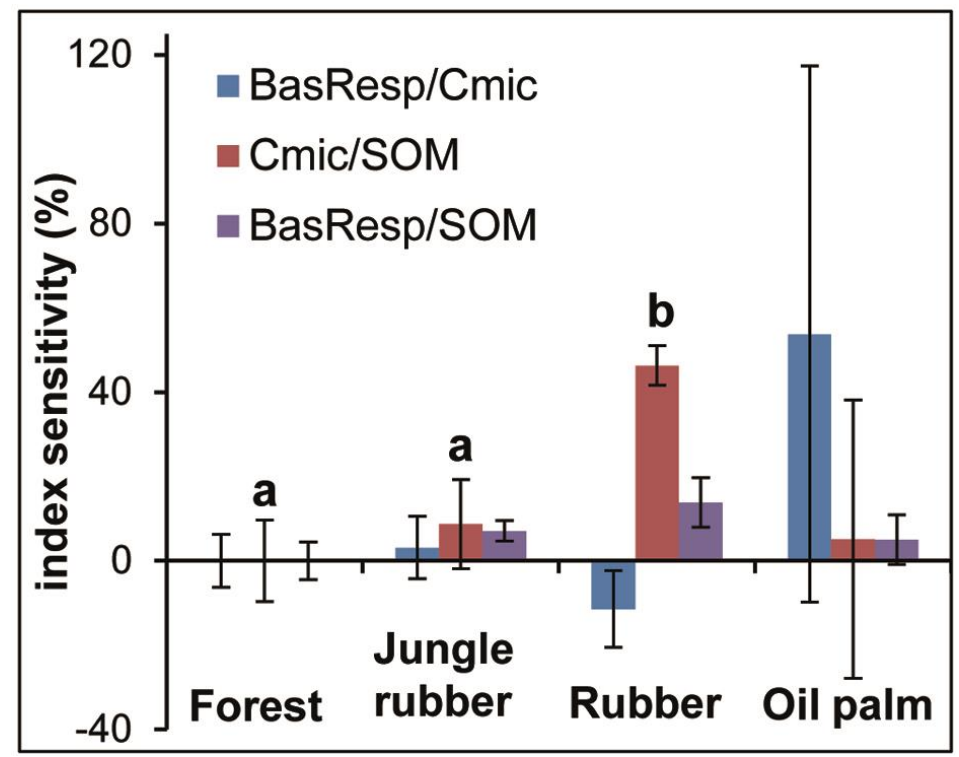

Figure 3-15: Sensitivity of microbial activity indices by land-use type.

The sensitivity was calculated by: $\mathrm{S}_{\mathrm{i}}=\left(\mathrm{I}_{\mathrm{p}}-\mathrm{I}_{\mathrm{f}}\right) / \mathrm{I}_{\mathrm{f}} * 100$; where $S_{i}$ is the index sensitivity, $I_{p}$ is the index value in a plantation site and $I_{f}$ is the mean index value under forest. Indices showed no effect on the metabolic quotient (BasResp/Cmic) or the specific basal respiration (BasResp/SOM). Oil palm plantations showed a high variability of indices. When removed from the analysis, the microbial quotient (Cmic/SOM) was higher under rubber than forest and jungle rubber (ANOVA, n=4).

\section{Sensitivity of soil fertility indicators to SOM losses}

To demonstrate the sensitivity or resistance of soil fertility indicators, they were related to SOM losses according to the suggested concept (Fig. 3-13). The basal respiration showed a strong $\left(\mathrm{R}^{2}=0.91\right)$ and positive relationship with the $\mathrm{C}$ content (Fig. 3-16), better explained by a logarithmic than by a linear model (Table 3-7). This indicates a strong negative effect of SOM losses on SOM availability at a low $\mathrm{C}$ content, but only a weak negative effect at high $\mathrm{C}$ content. The regression slope estimated only for forest sites (Fig. 3-16, dashed-line) showed that the basal respiration decreased proportionally $30 \%$ less than the $\mathrm{C}$ content. Thus, soils under natural conditions had higher specific basal respiration (BasResp/SOM) at lower C content. Because of the logarithmic relationship, the specific basal respiration of soils under plantations also increased until the $\mathrm{C}$ content reached $2.7 \%$; i.e. when the tangent of the non-linear regression line crossed the axes' origin. Below $2.7 \% \mathrm{C}$ content, the basal respiration decreased faster than the $\mathrm{C}$ content, indicating a strong decrease of SOM availability at low $\mathrm{C}$ content. This limit was similar to the average $\mathrm{C}$ content under rubber plantations and above the average under oil palm 
plantations. Accordingly, the difference in basal respiration between oil palm plantations and rubber plantations was higher than the difference in $\mathrm{C}$ content.

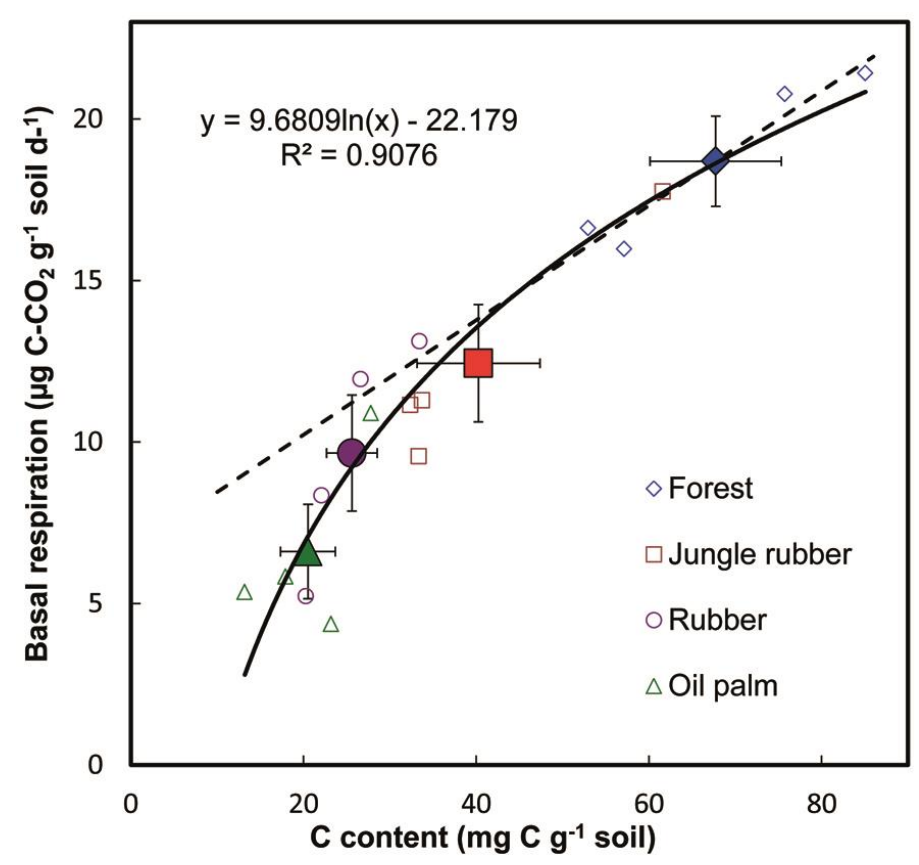

Figure 3-16: Logarithmic relationship between basal respiration and $\mathrm{C}$ content.

Non-linear regression (solid line) fitted with the 16 sites (empty dots). The basal respiration is resistant at high C content but strongly decreases at low $\mathrm{C}$ content. Land-use types' averages (filled dots; mean $\pm \mathrm{SE}$; $\mathrm{n}=4$ ) were not used for the regression. The relationship for forest plots (dashed-line) showed that the basal respiration under natural conditions does not increase proportionally with an increased amount of $\mathrm{C}$ sequestrated in soil.

The $\mathrm{C}$ content was strongly correlated with all measured parameters $(\mathrm{r}>0.85)$. Therefore, linear and non-linear regressions were fitted to assess the sensitivity of microbial activities, SOC pools and nutrients independently of the land-use type (Fig. 3-17). Each indicator was standardized to the forest mean, and the $\mathrm{C}$ content was used as an independent variable. The decrease of all variables, except DOC and phosphatase activity, was not proportional to the $\mathrm{C}$ content decrease: the slope of the linear regression (eq. 2) and the exponent of the non-linear regression (eq. 3) were significantly different from 1 (Table 3-7). The light fraction was sensitive to SOM losses as indicated by a slope and an exponent greater than 1 . In contrast, $\mathrm{N}$ and available $\mathrm{P}$ were resistant to SOC losses, resulting in a relative nutrient enrichment under plantations. While the power of the ANOVA was too low to reveal significant land-use effects on available P, regressions showed a decrease with $\mathrm{C}$ content and thereby an effect of land-use changes. Similar to the basal respiration and the nutrients, the microbial biomass decrease was resistant to SOM losses. The linear model had a higher $\mathrm{R}^{2}$ for nutrient contents ( $\mathrm{N}$ and $\mathrm{P}$ ). For all other indicators, the 
variability explained by the exponential model $\left(\mathrm{R}^{2}\right.$ ranged from 0.73 to 0.91$)$ was slightly higher. Nonetheless, exponential models explain only around $1 \%$ more of the variability (Table 3-7).

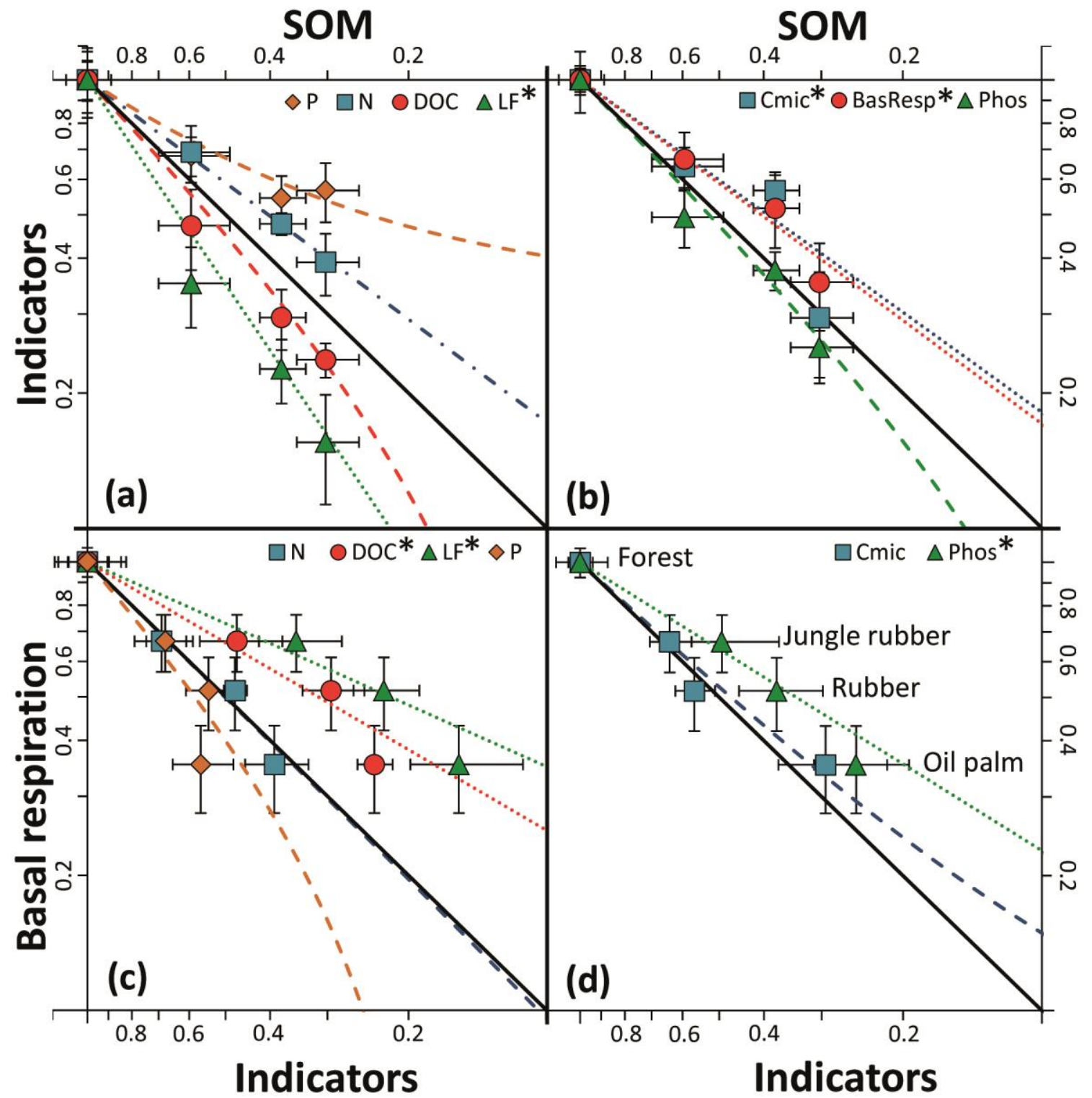

Figure 3-17: Sensitivity of soil fertility indicators to SOM losses $(a, b)$ and the coupling of indictors with basal respiration $(\mathrm{c}, \mathrm{d})$.

Indicators with non-proportional decrease are indicated with a star in the legend. Linear relationships (dashed lines) and non-linear relationships (dotted lines) were fitted on 16 sites. Note the logarithmic scale of the axes. Because of the logarithmic axis scale, the linear relationships are represented by a curve.

The same analysis was repeated with the basal respiration as a dependent variable to observe its coupling to the decrease of nutrients, labile pools and microbial activity (Fig. 3-17). The basal respiration decreased proportionally with the microbial biomass and $\mathrm{N}$ decrease, 
indicating that it was tightly coupled with these two variables. The available $\mathrm{P}$ had a slope of 1.2 but was not significantly different from 1 because of a large confidence interval (high variability between the plots). The basal respiration was less coupled with these variables than with the microbial biomass and the $\mathrm{N}$ content. For variables decreasing non-proportionally with the basal respiration, the exponential models $\left(\mathrm{R}^{2}\right.$ ranged from 0.80 to 0.88$)$ explained 1 to $6 \%$ more variability than the linear models (Table 3-7).

Table 3-6. Linear and non-linear regressions between indicators and SOM as independent variable, and between the basal respiration and indicators as independent variables.

\begin{tabular}{|c|c|c|c|c|c|}
\hline & Regression type $^{1}$ & $\mathbf{a}^{2}$ & CI down & CI up & $\mathbf{R}^{2}$ \\
\hline \multicolumn{6}{|c|}{ indicator versus SOM } \\
\hline \multirow{2}{*}{$\begin{array}{l}\text { Basal } \\
\text { respiration } *^{3}\end{array}$} & 1 & 0.86 & 0.77 & 0.94 & 0.90 \\
\hline & $\mathrm{nl}$ & 0.77 & 0.66 & 0.88 & 0.91 \\
\hline \multirow{2}{*}{$\begin{array}{l}\text { Microbial } \\
\text { biomass* }\end{array}$} & 1 & 0.84 & 0.70 & 0.98 & 0.72 \\
\hline & $\mathrm{nl}$ & 0.74 & 0.56 & 0.92 & 0.73 \\
\hline \multirow{3}{*}{$\begin{array}{c}\text { Acid } \\
\text { phosphatase }\end{array}$} & 1 & 1.05 & 0.92 & 1.19 & 0.82 \\
\hline & $\mathrm{nl}$ & 1.08 & 0.83 & 1.33 & 0.82 \\
\hline & 1 & 1.10 & 0.98 & 1.22 & 0.84 \\
\hline DOC & $\mathrm{nl}$ & 1.19 & 0.94 & 1.44 & 0.84 \\
\hline \multirow{3}{*}{$\begin{array}{c}\text { Light } \\
\text { fraction* }\end{array}$} & 1 & 1.24 & 1.09 & 1.39 & 0.82 \\
\hline & $\mathrm{nl}$ & 1.52 & 1.14 & 1.89 & 0.83 \\
\hline & 1 & 0.85 & 0.81 & 0.88 & 0.98 \\
\hline \multirow[t]{2}{*}{$\mathrm{N}$ content* } & $\mathrm{nl}$ & 0.76 & 0.72 & 0.81 & 0.98 \\
\hline & 1 & 0.66 & 0.54 & 0.79 & 0.75 \\
\hline \multirow[t]{2}{*}{$\mathrm{P}$ available* } & $\mathrm{nl}$ & 0.54 & 0.40 & 0.68 & 0.73 \\
\hline & basal res & pirati & $s$ indicator & & \\
\hline \multirow{2}{*}{$\begin{array}{c}\text { Microbial } \\
\text { biomass }\end{array}$} & 1 & 0.95 & 0.79 & 1.10 & 0.75 \\
\hline & $\mathrm{nl}$ & 0.98 & 0.72 & 1.24 & 0.74 \\
\hline \multirow{3}{*}{$\begin{array}{c}\text { Acid } \\
\text { phosphatase* }\end{array}$} & 1 & 0.78 & 0.69 & 0.87 & 0.86 \\
\hline & $\mathrm{nl}$ & 0.64 & 0.53 & 0.75 & 0.88 \\
\hline & 1 & 0.74 & 0.63 & 0.85 & 0.79 \\
\hline DOC* & $\mathrm{nl}$ & 0.60 & 0.47 & 0.73 & 0.80 \\
\hline \multirow{3}{*}{$\begin{array}{c}\text { Light } \\
\text { fraction* }\end{array}$} & 1 & 0.65 & 0.55 & 0.75 & 0.77 \\
\hline & $\mathrm{nl}$ & 0.46 & 0.36 & 0.55 & 0.83 \\
\hline & 1 & 1.00 & 0.90 & 1.11 & 0.89 \\
\hline \multirow[t]{2}{*}{$\mathrm{N}$ content } & $\mathrm{nl}$ & 0.99 & 0.83 & 1.15 & 0.89 \\
\hline & 1 & 1.20 & 0.97 & 1.44 & 0.78 \\
\hline $\mathrm{P}$ available & $\mathrm{nl}$ & 1.20 & 0.84 & 1.55 & 0.75 \\
\hline
\end{tabular}

1 l: linear regression; $n l=n o n-l i n e a r$ regression 2 Estimated parameter of the linear $(y=a x+1-a)$ and non-linear $(y=$ $\mathrm{x}^{\mathrm{a}}$ ) regressions 3 Stars indicate a non-proportional decrease between variables 
In summary, soil fertility indicators decreased under plantations compared to forest, but not all indicators were equally affected. While classical indices yielded very variable results, regressions highlighted clear differences in indicator sensitivity and resistance to land-use changes. 


\subsubsection{Discussion}

The results confirmed the hypothesis that rainforest conversion to oil palm and rubber plantations negatively affects soil fertility, reflected in the decrease of all measured biological and chemical indicators. The basal respiration and microbial biomass decrease under rubber plantations (48 and $43 \%$, respectively) were surprisingly similar to the decreases reported for rubber plantations in India (56 and $36 \%$ respectively; Dinesh et al., 2004), despite differences in climate, soil type and microbial biomass between both studies. The measured microbial biomass (169 $\mu \mathrm{g} \mathrm{C} \mathrm{g}^{-1}$ soil) and the microbial quotient $(0.9 \%)$ fell into the low range of microbial biomass (80-390 $\mu \mathrm{g} \mathrm{C} \mathrm{g}^{-1}$ soil) and microbial quotient (0.5-2.4 \%) measured in Malaysian plantations (Adachi et al., 2006; Haron et al., 1998).

All measured parameters were highly correlated with SOM, confirming the usefulness of SOM as an indicator and umbrella property of soil fertility. Differences in the indicators' sensitivity, however, show that quantifying SOM losses alone is insufficient to assess the impact of land-use change on soil fertility. Indeed, the SOM availability and the microbial activity, measured based on basal respiration and microbial biomass, were resistant to SOM losses, whereas the measured labile pools showed the same pattern (DOC) or were sensitive (LF) to SOM losses. A stronger response of labile pools to SOM losses was expected because of their sensitivity to land-use changes (Bolinder et al., 1999). Nonetheless, the resistance of basal respiration and microbial biomass to those losses contradicts the general view that biological indicators are also sensitive indicators of land-use changes and decrease in SOM quality (e.g. Mganga \& Kuzyakov, 2014).

The metabolic quotient was not affected by land-use changes, as reflected by a proportional decrease between basal respiration and microbial biomass. Therefore, the highest specific basal respiration under plantations resulted not from a lower $\mathrm{C}$ use efficiency of the microbial community but rather from a relative increase of the available organics to support microbial activity. SOM availability, however, should decrease faster than total SOM losses. This is because SOM labile pools are mineralized first, resulting in a relative accumulation of refractory SOM having a lower availability (Six et al., 2002). The decoupling between basal respiration or microbial biomass and labile SOM pools indicates that the microbial activity was not limited by the amount of labile SOM pools. Furthermore, SOM decomposition rates were very low compared to the pool's size, and basal respiration did not decrease over two months after the 
initial $\mathrm{CO}_{2}$-flush, resulting in zero-order kinetics. This type of kinetics characterizes reactions that are not limited by the substrate concentration but by other factors such as the catalyst amount (Paul and Clark, 1996). The strong decrease of labile pools, the resistance of basal respiration to SOM losses and the SOM decomposition kinetics strongly suggest that SOM decomposition did not depend on SOM quantity or quality. Interestingly, higher or similar specific basal respiration was also observed in subsoil compared to topsoil (Agnelli et al., 2004; Salomé et al., 2010), even though subsoil SOM is considered more recalcitrant than topsoil SOM (Rumpel and Kögel-Knabner, 2011). Input of fresh C was shown to control the decomposition of recalcitrant SOM in the subsoil by stimulating microorganisms (Fontaine et al., 2007). The input of leaf and root residues as well as of root exudates to soil could therefore stimulate microbial activity under plantations, although little of the fresh input remained stabilized in the SOM. Accordingly, the stronger decrease of basal respiration under oil palm compared to rubber plantations reflects the highly reduced leaf litter input in oil palm plantations (Kotowska et al., 2015). Based on the $\delta^{13} \mathrm{C}$ values of SOM in the Ah horizon, Guillaume et al. (2015) already hypothesized slower decomposition rates under oil palm and that the absence of ${ }^{13} \mathrm{C}$ enrichment with depth indicated that the fresh C input was not stabilized in the SOM.

SOM losses resulted in a relative enrichment of $\mathrm{N}$ and available $\mathrm{P}$ under plantations. Since no fertilizers are applied in jungle rubber and only minimal amounts near the trees in oil palm and occasionally in rubber plantations, the relative enrichment in these nutrients mainly arose from $\mathrm{CO}_{2}$ losses through $\mathrm{C}$ mineralization. Therefore, relative nutrient availability increases. Phosphorus is generally the most limiting nutrient in heavily-weathered tropical soils, while $\mathrm{N}$ is in relative excess (Cleveland et al., 2006, 2003; Vitousek, 1984). The fact that basal respiration decreased more strongly than the phosphorus decrease indicates that phosphorus was not the main limiting factor of microbial activity under plantations. Phosphatase activity reflects microorganisms demand for $\mathrm{P}$, which increases with increasing P-limitations (Allison et al., 2011; Weintraub et al., 2012). Phosphatase activity decreased more strongly than the microbial biomass, supporting the hypothesis of lower $\mathrm{P}$ demand under plantations. The proportional decreases of $\mathrm{N}$, microbial biomass and basal respiration suggest that $\mathrm{N}$ content was a limiting factor for microbial activity and for their ability to mineralize SOM. Therefore, SOM availability and microbial activity are resistant to SOM losses not because the $\mathrm{C}$ availability decreased, but because $\mathrm{C}$ was lost faster than N. Fontaine et al. (2003) already suggested that, at the community 
level, microorganisms can shift their $\mathrm{C}$ sources to more recalcitrant SOM pools, if nutrients are not sequestrated by $\mathrm{r}$-strategist microorganisms feeding on the more labile SOM.

Standardizing soil properties or process intensities to the reference (here undisturbed rainforest sites) using eq. 2 and 3 provided a simple and efficient method to discriminate between proportional and non-proportional decreases of two variables. Consequently, the sensitivity of indicators to SOM losses, and thereby to land-use changes, can be assessed straightforwardly by the confidence interval of the estimated parameter alone. The discrimination between exponential or linear relationships between two variables should also be straightforward using the model with the highest $\mathrm{R}^{2}$. Nonetheless, the differences in the variability explained by both models were not higher than $7 \%$. Because the values predicted by the models differ the most at low C content (Fig. 3-13), the determination of the variables' responses would be improved by adding to the analysis sites with lower $\mathrm{C}$ content (even more strongly degraded). Moreover, including sites with lower $\mathrm{C}$ content would enable testing whether the relationships reach zero for both variables or not; i.e. following models such as $\mathrm{y}=\mathrm{a} * \log (\mathrm{x})+\mathrm{b}$ or $\mathrm{a}^{*} \mathrm{e}^{\left(\mathrm{x}^{*} \mathrm{~b}\right)}$.

Non-linear relationships between variables challenged the use of indices to assess the sensitivity of soil properties. First, sites with the lowest $\mathrm{C}$ content do not necessarily show the strongest change in indices compared to the reference sites. Consequently, the intensity of the indices change is not related with the intensity of soil degradation. Indices changes in the case of nonlinear relationships should therefore be evaluated according to the $\mathrm{C}$ content level. Second, the derivative of a non-linear model varies with the $\mathrm{C}$ content. This makes indices variability within land-use type inconsistent among land-use types having different average $\mathrm{C}$ content, but similar $\mathrm{C}$ content variability. This leads to difficulties in reaching the condition of variance homogeneity when testing land-use effects with ANOVA.

\subsubsection{Conclusion}

SOM losses after tropical forest conversion to oil palm and rubber plantations were associated with a strong decrease of chemical and biological indicators of soil fertility. The new approach was advantageous compared to classical indices and allowed a simple discrimination between sensitive and resistant indicators to SOM losses and, thus, to land-use changes. Surprisingly, SOM availability and microbial activity were resistant to SOM losses despite a strong decrease 
of labile SOM pools. This is explained by the input of leaf and root residues, as well as root exudates to soil, maintaining microbial respiratory activity. The lower depletion of nutrients compared to SOM, leading to a higher nutrients-to-SOM ratio under plantations, is the second explanation. The resistance of the microbial activity to SOM losses indicates that the microbial functions sustain SOM losses. Nonetheless, the resistance of the microbial activity weakened with increasing SOM losses. This occurred up to a turning point where SOM losses were associated with a drop in microbial activity. Management practices that would slightly reduce SOM losses in intensive plantations could therefore significantly mitigate the decrease of microbial activity and potentially of soil fertility. Spreading the residues of oil palm fronds in the plantation instead of stacking them in specific locations could increase SOM and therefore microbial activity by increasing $\mathrm{C}$ input and decreasing SOM losses by soil erosion. In conclusion, the suggested and tested new approach allowed the dynamic assessment of sensitive and resistant soil fertility indicators. This is an important step forward in evaluating the effects of natural ecosystem conversion to intensive plantations and can be useful for estimating ecosystem service changes.

\subsubsection{Acknowledgments}

This study was funded by the Deutsche Forschungsgemeinschaft (DFG) in the framework of the collaborative German - Indonesian research project CRC990. We thank the following persons and organizations for granting us access to and use of their properties: village leaders, local plot owners, PT REKI and Bukit Duabelas National Park. This study was conducted using samples collected based on collection permit No. S.305/KKH-2/2013 recommended by the Indonesian Institute of Sciences (LIPI) and issued by the Ministry of Forestry (PHKA).

\subsubsection{References}

Abood, S. a., Lee, J.S.H., Burivalova, Z., Garcia-Ulloa, J., Koh, L.P., 2014. Relative contributions of the logging, fiber, oil palm, and mining industries to forest loss in Indonesia. Conserv. Lett. 8, 58-67. doi:10.1111/conl.12103

Adachi, M., Bekku, Y.S., Rashidah, W., Okuda, T., Koizumi, H., 2006. Differences in soil respiration between different tropical ecosystems. Appl. Soil Ecol. 34, 258-265. doi:10.1016/j.apsoil.2006.01.006 
Agnelli, A., Ascher, J., Corti, G., Ceccherini, M.T., Nannipieri, P., Pietramellara, G., 2004. Distribution of microbial communities in a forest soil profile investigated by microbial biomass, soil respiration and DGGE of total and extracellular DNA. Soil Biol. Biochem. 36, 859-868. doi:10.1016/j.soilbio.2004.02.004

Allison, S.D., Weintraub, M.N., Gartner, T.B., Waldrop, M.P., 2011. Evolutionary-economic principles as regulators of soil enzyme production and ecosystem function, in: Soil Enzymology. Springer Berlin Heidelberg, pp. 229-243.

Alvarez, C.R., Alvarez, R., Grigera, M.S., Lavado, R.S., 1998. Associations between organic matter fractions and the active soil microbial biomass. Soil Biol. Biochem. 30, 767-773. doi:10.1016/S0038-0717(97)00168-5

Anderson, T.H., 2003. Microbial eco-physiological indicators to asses soil quality. Agric. Ecosyst. Environ. 98, 285-293. doi:10.1016/S0167-8809(03)00088-4

Anderson, T.H., Domsch, K.H., 1990. Application of eco-physiological quotients (qCO2 and qD) on microbial biomasses from soils of different cropping histories. Soil Biol. Biochem. 22, 251-255. doi:10.1016/0038-0717(90)90094-G

Anderson, T.H., Domsch, K.H., 1989. Ratios of microbial biomass carbon to total organic carbon in arable soils. Soil Biol. Biochem. 21, 471-479. doi:10.1016/0038-0717(89)90117-X

Askari, M.S., Holden, N.M., 2014. Indices for quantitative evaluation of soil quality under grassland management. Geoderma 230-231, 131-142. doi:10.1016/j.geoderma.2014.04.019

Barlow, J., Gardner, T. a, Araujo, I.S., Avila-Pires, T.C., Bonaldo, a B., Costa, J.E., Esposito, M.C., Ferreira, L. V, Hawes, J., Hernandez, M.I.M., Hoogmoed, M.S., Leite, R.N., LoMan-Hung, N.F., Malcolm, J.R., Martins, M.B., Mestre, L. a M., Miranda-Santos, R., Nunes-Gutjahr, a L., Overal, W.L., Parry, L., Peters, S.L., Ribeiro-Junior, M. a, da Silva, M.N.F., da Silva Motta, C., Peres, C. a, 2007. Quantifying the biodiversity value of tropical primary, secondary, and plantation forests. Proc. Natl. Acad. Sci. U. S. A. 104, 1855518560. doi:10.1073/pnas.0703333104 
Barnes, A.D., Jochum, M., Mumme, S., Haneda, N.F., Farajallah, A., Widarto, T.H., Brose, U., 2014. Consequences of tropical land use for multitrophic biodiversity and ecosystem functioning. Nat. Commun. 5, 1-7. doi:10.1038/ncomms6351

Bastida, F., Zsolnay, a., Hernández, T., García, C., 2008. Past, present and future of soil quality indices: A biological perspective. Geoderma 147, 159-171.

doi:10.1016/j.geoderma.2008.08.007

Bauer, A., Black, A.L., 1994. Quantification of the Effect of Soil Organic Matter Content on Soil Productivity. Soil Sci. Soc. Am. J. 58, 185-193.

doi:10.2136/sssaj1994.03615995005800010027x

Bloem, J., Schouten, A.J., Sørensen, S.J., Rutgers, M., Werf, A., Breure, A.M., Hopkins, D.W., Benedetti, A., 2006. Monitoring and evaluating soil quality., in: Bloem et al., J. (Ed.), Microbiological Methods for Assessing Soil Quality. CABI, Wallingford, pp. 23-49.

Bolinder, M. a., Angers, D. a., Gregorich, E.G., Carter, M.R., 1999. The response of soil quality indicators to conservation management. Can. J. Soil Sci. 79, 37-45. doi:10.4141/S97-099

Bonde, T.A., Lindberg, T., 1988. Nitrogen Mineralization Kinetics in Soil During Long-term Aerobic Laboratory Incubations: A Case Study. J. Environ. Qual. 17, 414-417. doi:10.2134/jeq1988.00472425001700030011x

Bruijnzeel, L.A., 2004. Hydrological functions of tropical forests: Not seeing the soil for the trees? Agric. Ecosyst. Environ. 104, 185-228. doi:10.1016/j.agee.2004.01.015

Cleveland, C.C., Reed, S.C., Townsend, A.R., 2006. Nutrient regulation of organic matter decomposition in a tropical rain forest. Ecology 87, 492-503. doi:10.1890/05-0525

Cleveland, C.C., Townsend, A.R., Schmidt, S.K., 2003. Phosphorus Limitation of Microbial Processes in Moist Tropical Forests: Evidence from Short-term Laboratory Incubations and Field Studies. Ecosystems 5, 680-691. doi:10.1007/s10021-002-0202-9

Dinesh, R., Ghoshal Chaudhuri, S., Sheeja, T.E., 2004. Soil biochemical and microbial indices in wet tropical forests: Effects of deforestation and cultivation. J. Plant Nutr. Soil Sci. 167, 24-32. doi:10.1002/jpln.200321254 
Don, A., Schumacher, J., Freibauer, A., 2011. Impact of tropical land-use change on soil organic carbon stocks - a meta-analysis. Glob. Chang. Biol. 17, 1658-1670. doi:10.1111/j.13652486.2010.02336.x

Fontaine, S., Barot, S., Barré, P., Bdioui, N., Mary, B., Rumpel, C., 2007. Stability of organic carbon in deep soil layers controlled by fresh carbon supply. Nature 450, 277-280. doi:10.1038/nature06275

Fontaine, S., Mariotti, A., Abbadie, L., 2003. The priming effect of organic matter: A question of microbial competition? Soil Biol. Biochem. 35, 837-843. doi:10.1016/S00380717(03)00123-8

Ganzhara, N.F., 1998. Humus, soil properties, and yield. Eurasian soil Sci. 31, 738-745.

Gatto, M., Wollni, M., Qaim, M., 2015. Oil palm boom and land-use dynamics in Indonesia: The role of policies and socioeconomic factors. Land use policy 46, 292-303. doi:10.1016/j.landusepol.2015.03.001

Gibbs, H.K., Ruesch, a S., Achard, F., Clayton, M.K., Holmgren, P., Ramankutty, N., Foley, J. a, 2010. Tropical forests were the primary sources of new agricultural land in the 1980s and 1990s. Proc. Natl. Acad. Sci. U. S. A. 107, 16732-16737. doi:10.1073/pnas.0910275107

Gil-Sotres, F., Trasar-Cepeda, C., Leirós, M.C., Seoane, S., 2005. Different approaches to evaluating soil quality using biochemical properties. Soil Biol. Biochem. 37, 877-887. doi:10.1016/j.soilbio.2004.10.003

Guillaume, T., Damris, M., Kuzyakov, Y., 2015. Losses of soil carbon by converting tropical forest to plantations: Erosion and decomposition estimated by $\delta 13 \mathrm{C}$. Glob. Chang. Biol. doi:10.1111/gcb.12907

Haile-Mariam, S., Collins, H.P., Wright, S., Paul, E.A., 2008. Fractionation and Long-Term Laboratory Incubation to Measure Soil Organic Matter Dynamics. Soil Sci. Soc. Am. J. 72, 370. doi:10.2136/sssaj2007.0126

Haron, K., Brookes, P.C., Anderson, J.M., Zakaria, Z.Z., 1998. Microbial biomass and soil organic matter dynamics in oil palm (Elaeis guineensis jacq.) plantations, West Malaysia. Soil Biol. Biochem. 30, 547-552. doi:10.1016/S0038-0717(97)00217-4 
Hedley, M.J., Stewart, J.W.B., Chauhan, B.S., 1982. Changes in Inorganic and Organic Soil Phosphorus Fractions Induced by Cultivation Practices and by Laboratory Incubations. Soil Sci. Soc. Am. J. 46, 970. doi:10.2136/sssaj1982.03615995004600050017x

Insam, H., Domsch, K.H., 1988. Relationship between soil organic carbon and microbial biomass on chronosequences of reclamation sites. Microb. Ecol. 15, 177-188. doi:10.1007/BF02011711

Joergensen, R.G., 2010. Organic Matter and Micro-Organisms in Tropical Soils, in: Dion, P. (Ed.), Soil Biology and Agriculture in the Tropics. Springer-Verlag Berlin Heidelberg, pp. 17-44. doi:10.1007/978-3-642-05076-3

John, B., Yamashita, T., Ludwig, B., Flessa, H., 2005. Storage of organic carbon in aggregate and density fractions of silty soils under different types of land use. Geoderma 128, 63-79. doi:10.1016/j.geoderma.2004.12.013

Kandeler, E., Stemmer, M., Klimanek, E.-M., 1999. Response of soil microbial biomass, urease and xylanase within particle size fractions to long-term soil management. Soil Biol. Biochem. 31, 261-273. doi:10.1016/S0038-0717(98)00115-1

Kaschuk, G., Alberton, O., Hungria, M., 2010. Three decades of soil microbial biomass studies in Brazilian ecosystems: Lessons learned about soil quality and indications for improving sustainability. Soil Biol. Biochem. 42, 1-13. doi:10.1016/j.soilbio.2009.08.020

Kotowska, M.M., Leuschner, C., Triadiati, T., Meriem, S., Hertel, D., 2015. Quantifying aboveand belowground biomass carbon loss with forest conversion in tropical lowlands of Sumatra (Indonesia). Glob. Chang. Biol. doi:10.1111/gcb.12979

Lal, R., 2010. Enhancing Eco-efficiency in Agro-ecosystems through Soil Carbon Sequestration. Crop Sci. 50, 120-131. doi:10.2135/cropsci2010.01.0012

Lal, R., 2006. Enhancing crop yields in the developing countries through restoration of the soil organic carbon pool in agricultural lands. L. Degrad. Dev. 209, 197-209.

Letey, J., Sojka, R.E., Upchurch, D.R., Cassel, D.K., Olson, K.R., Payne, W. a, Petrie, S.E., Price, G.H., Reginato, R.J., Scott, H.D., Smethurst, P.J., Triplett, G.B., 2003. Deficiencies in the soil quality concept and its application. J. Soil Water Conserv. 58, 180-187. 
Margono, B.A., Potapov, P. V., Turubanova, S., Stolle, F., Hansen, M.C., 2014. Primary forest cover loss in Indonesia over 2000-2012. Nat. Clim. Chang. 4, 730-735. doi:10.1038/nclimate2277

Marx, M.-C., Wood, M., Jarvis, S.., 2001. A microplate fluorimetric assay for the study of enzyme diversity in soils. Soil Biol. Biochem. 33, 1633-1640. doi:10.1016/S00380717(01)00079-7

Mganga, K.Z., Kuzyakov, Y., 2014. Glucose decomposition and its incorporation into soil microbial biomass depending on land use in Mt. Kilimanjaro ecosystems. Eur. J. Soil Biol. 62, 74-82. doi:10.1016/j.ejsobi.2014.02.015

Mueller, C.W., Gutsch, M., Kothieringer, K., Leifeld, J., Rethemeyer, J., Brueggemann, N., Kögel-Knabner, I., 2014. Bioavailability and isotopic composition of $\mathrm{CO}_{2}$ released from incubated soil organic matter fractions. Soil Biol. Biochem. 69, 168-178. doi:10.1016/j.soilbio.2013.11.006

Murphy, J., Riley, J.P., 1962. A modified single solution method for the determination of phosphate in natural waters. Anal. Chim. Acta 27, 31-36. doi:10.1016/S00032670(00)88444-5

Paul, E.A., Clark, F.E., 1996. Dynamics of Residue Decomposition and Soil Organic Matter Turnover, in: Soil Microbiology and Biochemistry. Academic Press, San Diego, pp. 158178.

Powlson, D.S., Prookes, P.C., Christensen, B.T., 1987. Measurement of soil microbial biomass provides an early indication of changes in total soil organic matter due to straw incorporation. Soil Biol. Biochem. 19, 159-164. doi:10.1016/0038-0717(87)90076-9

Raiesi, F., Beheshti, A., 2015. Microbiological indicators of soil quality and degradation following conversion of native forests to continuous croplands. Ecol. Indic. 50, 173-185. doi:10.1016/j.ecolind.2014.11.008

Rumpel, C., Kögel-Knabner, I., 2011. Deep soil organic matter-a key but poorly understood component of terrestrial C cycle. Plant Soil 338, 143-158. doi:10.1007/s11104-010-0391-5 
Salomé, C., Nunan, N., Pouteau, V., Lerch, T.Z., Chenu, C., 2010. Carbon dynamics in topsoil and in subsoil may be controlled by different regulatory mechanisms. Glob. Chang. Biol. 16, 416-426. doi:10.1111/j.1365-2486.2009.01884.x

Schloter, M., Dilly, O., Munch, J.C., 2003. Indicators for evaluating soil quality. Agric. Ecosyst. Environ. 98, 255-262. doi:10.1016/S0167-8809(03)00085-9

Sharma, S.K., Ramesh, A., Sharma, M.P., Joshi, O.P., Govaerts, B., Steenwerth, K.L., Karlen, D.L., 2011. Microbial Community Structure and Diversity as Indicators for Evaluating Soil Quality, in: Lichtfouse, E. (Ed.), Biodiversity, Biofuels, Agroforestry and Conservation Agriculture, Sustainable Agriculture Reviews. Springer Netherlands, Dordrecht, pp. 317358. doi:10.1007/978-90-481-9513-8_11

Six, J., Conant, R.T., Paul, E.A., Paustian, K., 2002. Stabilization mechanisms of soil organic matter: Implications for C-saturation of soils. Plant Soil 155-176.

Sparling, G.P., 1992. Ratio of microbial biomass carbon to soil organic carbon as a sensitive indicator of changes in soil organic matter. Soil Res. 30, 195-207.

Vance, E.D., Brookes, P.C., Jenkinson, D.S., 1987. An extraction method for measuring soil microbial biomass C. Soil Biol. Biochem. 19, 703-707. doi:10.1016/0038-0717(87)900526

Vitousek, P.M., 1984. Litterfall , Nutrient Cycling, and Nutirent Limitation in Tropical Forests 65, 285-298.

Von Lützow, M., Kogel-Knabner, I., Ekschmitt, K., Matzner, E., Guggenberger, G., Marschner, B., Flessa, H., 2006. Stabilization of organic matter in temperate soils: mechanisms and their relevance under different soil conditions - a review. Eur. J. Soil Sci. 57, 426-445. doi:10.1111/j.1365-2389.2006.00809.x

Wagai, R., Kishimoto-Mo, A.W., Yonemura, S., Shirato, Y., Hiradate, S., Yagasaki, Y., 2013. Linking temperature sensitivity of soil organic matter decomposition to its molecular structure, accessibility, and microbial physiology. Glob. Chang. Biol. 19, 1114-1125. doi: $10.1111 / \mathrm{gcb} .12112$ 
Wang, W.J., Dalal, R.C., Moody, P.W., Smith, C.J., 2003. Relationships of soil respiration to microbial biomass, substrate availability and clay content. Soil Biol. Biochem. 35, 273284. doi:10.1016/S0038-0717(02)00274-2

Weintraub, S.R.., Wieder, W.R.., Cleveland, C.C.., Townsend, A.R.., 2012. Organic matter inputs shift soil enzyme activity and allocation patterns in a wet tropical forest.

Biogeochemistry 114, 1-14. doi:10.1007/s 10533-012-9812-2 


\section{Additional Studies}

This chapter presents studies that are not completed yet. The goal is to present the work that has been done and that still needs to be done before submitting a manuscript. The presented results are not exhaustive, but were selected because they strengthen the interpretation of the previous studies, present the potential of future manuscript or give guidelines for new researches.

\subsection{Study 4}

\section{Chemical characterization of soil organic matter}

Despite the fact that the role of the chemical recalcitrance as a stabilization process of SOM has recently been minimized (Schmidt et al., 2011), different chemical compositions require different enzymatic and assimilation processes. Consequently, the decomposition level of organic matter determines the type of active microorganisms and their ecological strategies. Therefore, the characterization of SOM chemical composition and thermal stability helps to determine which decomposition processes occur and gives an understanding of SOM functions in soil.

Three physical properties of SOM were used to assess its quality: infrared absorbance by Fourier transform infrared spectroscopy (FTIR), by excitation-emission fluorescence spectroscopy (3D fluorescence) and thermal stability by Rock-Eval pyrolysis (RE pyrolysis). Measurements were performed at the University of Lausanne in the research group of Eric Verrecchia with the collaboration of Remy Albrecht (FTIR, 3D fluorescence), Thierry Adatte (RE pyrolysis) and David Sebag (RE pyrolysis).

\subsubsection{Fourier transform infrared spectroscopy}

\section{Objectives and methods}

The objective was to assess the relative proportion of various chemical functional groups indicating the degree of SOM humification in the four land-use types. Three commonly used 
FTIR mode were compared to assess the most efficient technique: transmission FTIR (Trans), attenuated total reflection (ATR), and diffuse reflectance infrared Fourier transform (DRIFT) using a Spectrum Frontier Dual View (Perkin Elemer). Samples were oven-dried $\left(60{ }^{\circ} \mathrm{C}\right)$, grinded and laid on the crystal (ATR) or in sample cups (DRIFT) without any further preparation. For the Trans analysis, $\mathrm{KBr}$ pellet were prepared with $300 \mathrm{mg} \mathrm{KBR}$ and $3 \mathrm{mg}$ of grinded samples.

\section{Results and discussion:}

The signal of the mineral matrix was strong and masking signals of organic compounds in the horizons below the Ah horizon. While only the signal of aromatic compound $(\mathrm{C}=\mathrm{C} ; 1700-1575$ $\mathrm{cm}-1)$ could be isolated in ATR mode, the signal of aliphatic compound (C-H; 3000- $2800 \mathrm{~cm}^{-1}$ ) could also be isolated in Trans mode, allowing the calculation of the aromatic/aliphatic index (Fig. 4-1).

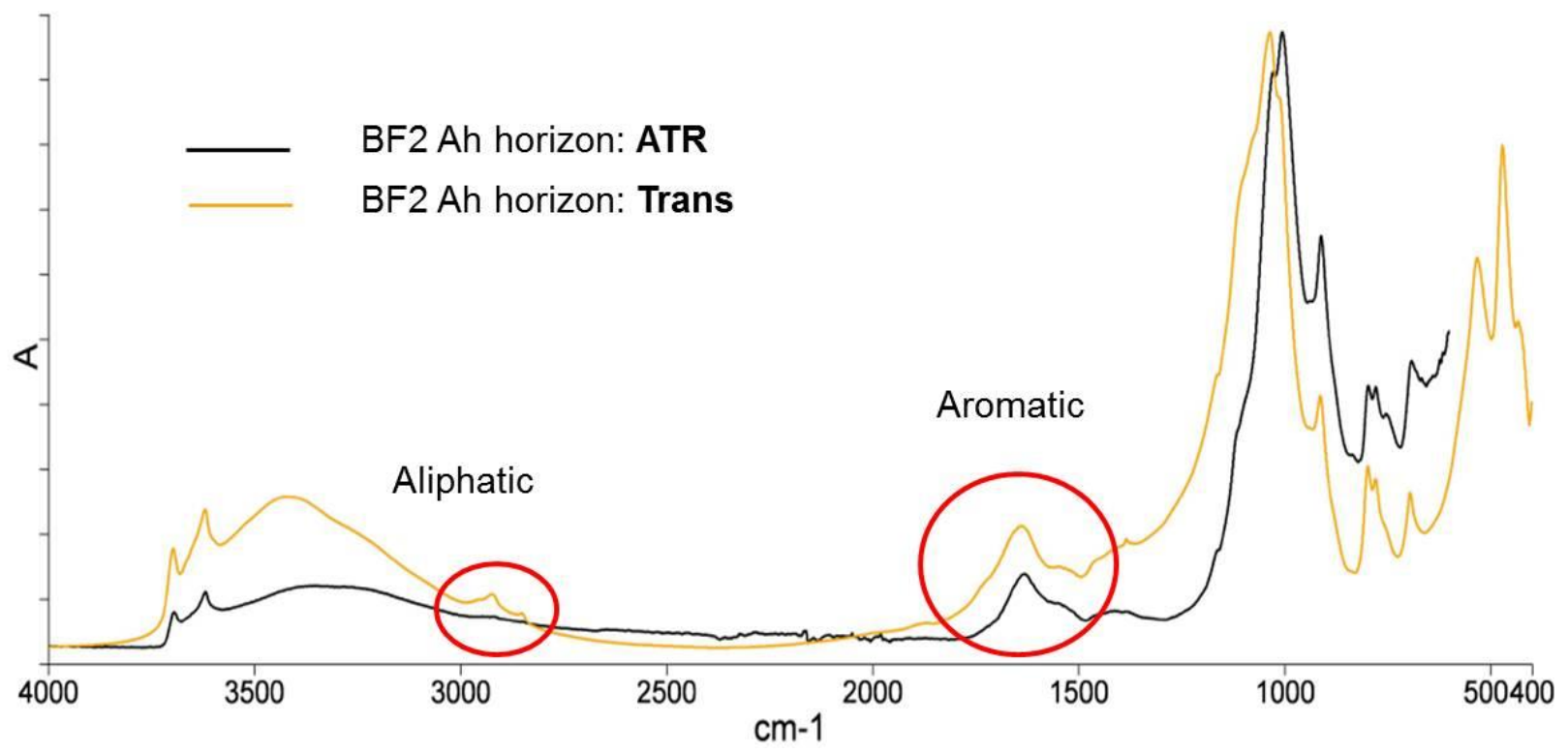

Figure 4-1: Comparison of absorption spectrums obtained by ATR and Trans modes on the same sample (Ah horizon of the forest site BF2).

This index is an indicator of the degree of SOM humification (Hsu \& Lo, 1999) and was calculated using the surface area under the peaks minus the background signal, using the software Perking Elemer spectrum 10. The first results showed an increase of the degree of SOM humification under plantations (Fig. 4-2). 


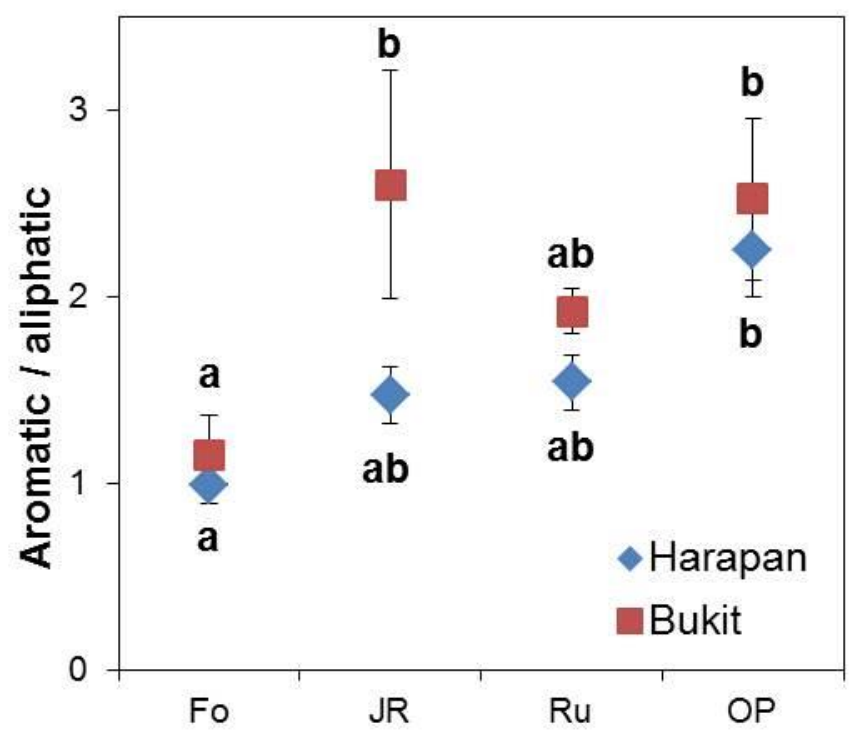

Figure 4-2: SOM recalcitrance measured by aliphatic / aromatic ratio

Ah horizon under forest $(\mathrm{Fo})$, jungle rubber $(\mathrm{JR})$, rubber $(\mathrm{Ru})$ and oil palm $(\mathrm{OP})$ in Harapan and Bukit region. Lower case letters indicates significant differences between land-use type (ANOVA; $\mathrm{p}<0.05$ ).

The SOM humification under rubber plantations tended to be lower than under oil palm plantations and similar to jungle rubber in Harapan region. Interestingly, this pattern was similar to the pattern observed for the basal respiration in the Harapan region; i.e. rubber was closer to jungle rubber than oil palm despite having similar $\mathrm{C}$ content. The higher degree of SOM humification in oil palm is explained by the absence of fresh organic matter input from leaves. Although, the Trans mode provided valuable information on the SOM composition, the DRIFT mode yielded better peaks separation (Fig. 4-3). As a result, further functional groups were identified (Demyan et al., 2012). The data are not analyzed yet, but further indices will be calculated based on the new identified peaks. In conclusion, the DRIFT mode was the most efficient mode in term of peaks separation and sample preparation. Furthermore, various methods have recently been developed to subtract the signal of mineral matrix (Margenot et al., 2015). Applying this method would further increase the analysis efficiency. 


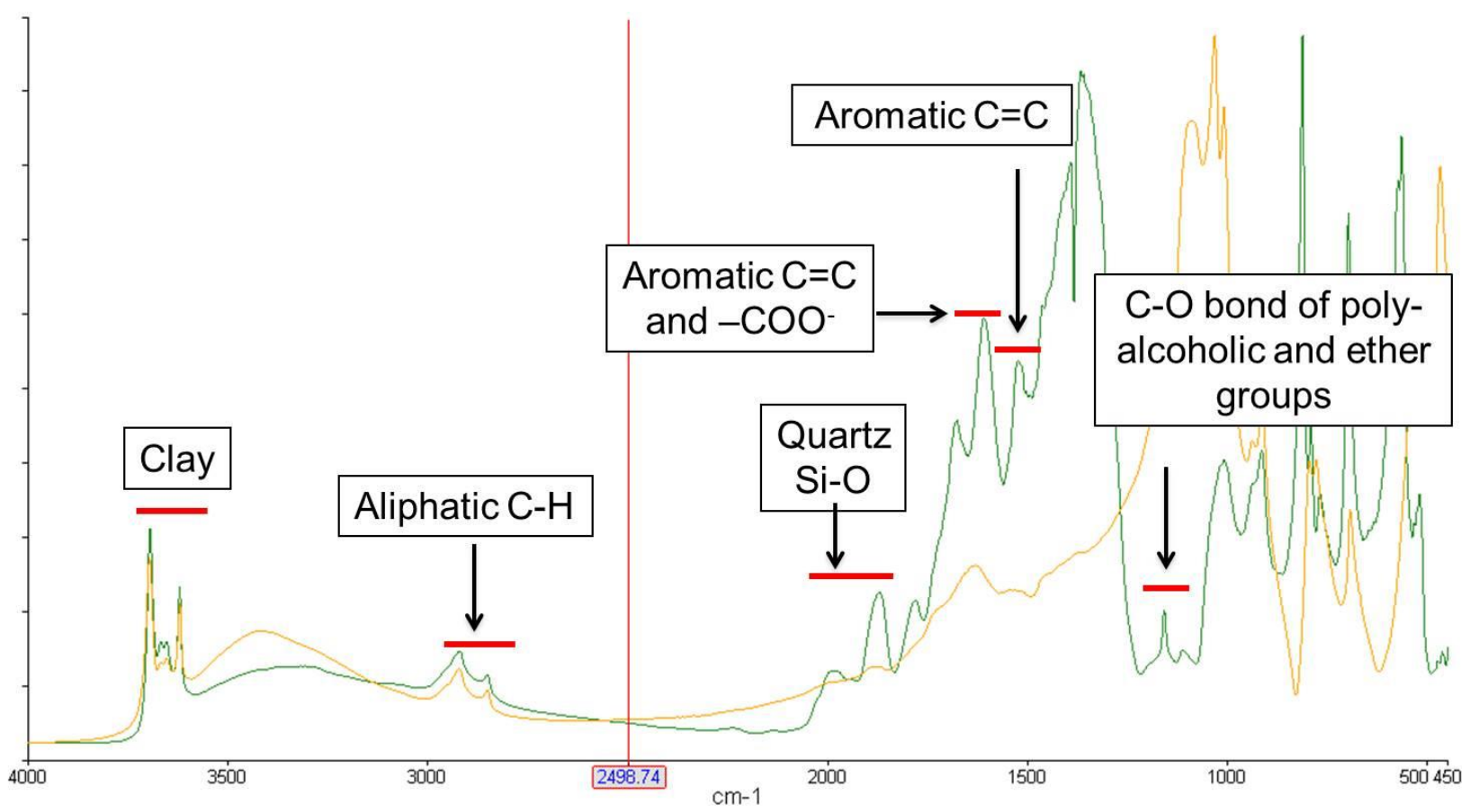

Figure 4-3: Comparison of absorption spectrums obtained by Trans and DRIFT mode.

Ah horizon of the forest site HF2: Correspondence between peaks and functional groups in DRIFT mode (Demyan et al., 2012).

\subsubsection{Excitation-emission fluorescence spectroscopy}

\section{Objectives and methods}

The 3D fluorescence was initially used to assess the quality of dissolved organic matter (DOM) in aquatic environments. Nevertheless, this technique can be used for DOM collected from the soil solution or for water extractable organic matter (WEOM) from soil samples to assess the impacts of land-use change on the degree of humification and the origin of DOM (Hassouna et $a l ., 2010)$. Fluorophores areas, i.e. areas with a fluorescence peak, in the excitation-emission matrix (EEM) were associated with various organic compounds (Chen et al., 2003; Fig. 4-4). Indices were developed to assess the degree of DOM humification (Cox et al., 2000; Ohno, 2002). However, these indices were based on 2D fluorescence (fixed excitation) and so, were not exploiting the full potential of 3D fluorescence. In order to determine the appropriate number of fluorophores and their intensity, multi-ways models such as PARAFAC are used to resolve the EEM matrix obtained by 3D fluorescence (Andersen \& Bro, 2003). Then, indices reflecting the degree of humification or the origin of DOM can be built according to the fluorophores intensity. 


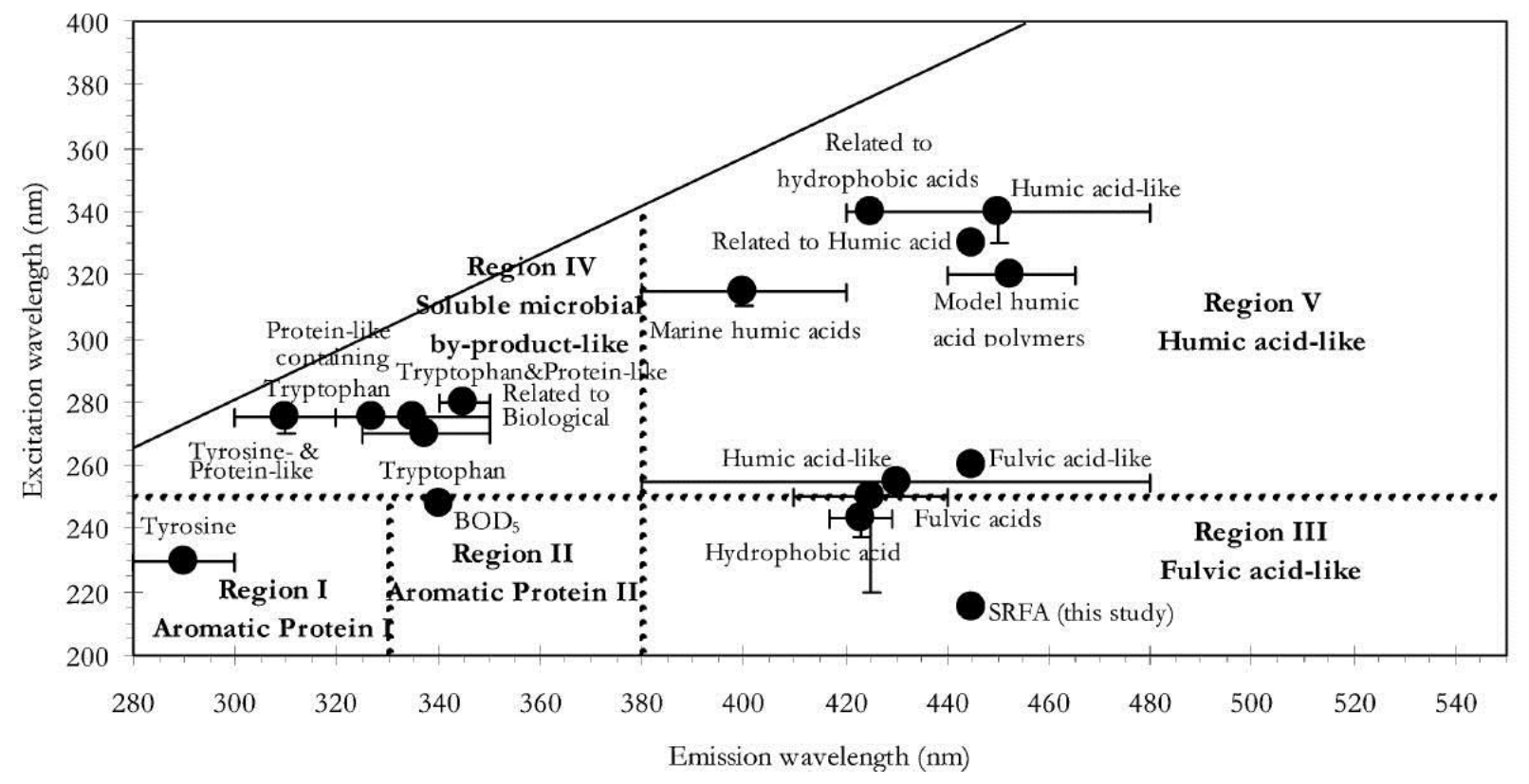

Figure 4-4: Location of EEM peaks and their associated organic compounds separated in five regions.

Reproduced from Chen et al. (2003).

Dissolved organic matter was collected below the Ah horizon $(15 \mathrm{~cm})$ and the Bt horizon $(75$ $\mathrm{cm}$ ) in the four land-use types in Harapan region (two replicates per depth and two replicate sites per land-use) every two weeks during one year. The 3D fluorescence technique was tested for the samples collected the $22^{\text {nd }}$ of August 2013. Additionally, WEDOM was extracted (1:10 solid:liquid) with deionized water (stirring: 1h, filtering: $0.45 \mu \mathrm{m}$ ) from the Ah horizons and the subsoil horizons corresponding to depth where the DOM was collected. If necessary, WEDOM samples where diluted to reach an absorbance close to 0.1 at $280 \mathrm{~nm}$.

\section{Results and discussions}

EEM matrix were produced for all samples, corrected for Rayleigh and Raman scattering and normalized to DOC concentration. Classic humification index (HIX, HIXo, IF) were calculated, but PARAFAC models and statistics are not carried out yet. The preliminary results showed changes in fluorophores between DOM and WEDOM and between depths as illustrated by the EEMs form forest site HF2 (Fig. 4-5). 


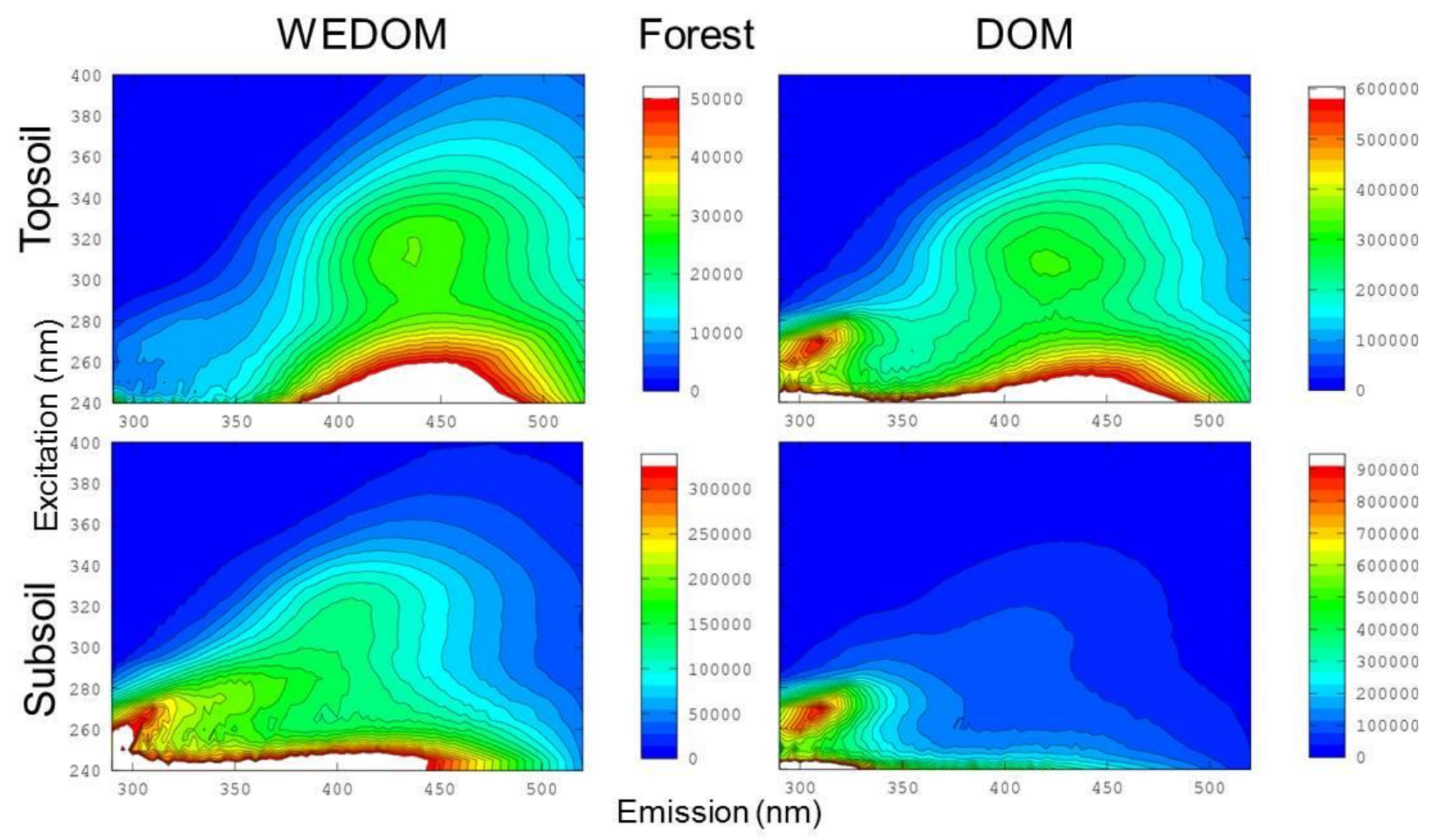

Figure 4-5: EEMs of DOM and WEDOM from the topsoil and subsoil of the forest site HF2. Data were corrected for the DOC content but the intensity scales vary between the four EEMs.

WEDOM and DOM from the topsoil are dominated by fluorophores corresponding to humic and fluvic acid-like compounds $(\mathrm{Em}>380 \mathrm{~nm})$. However, the fluorophore corresponding to the microbial-derived product (Em 290-380; Ex 250-300) was present in the DOM but absent in the WEDOM. In the subsoil, only one fluorophore corresponding to the microbial-derived products was identified in WEDOM and DOM. The preliminary results underlined the contribution of microbial-derived product to SOM in the subsoil and in DOM production. A similar fluorophore pattern was observed in the four land-use type. The PARAFAC analysis will enable a confirmation of these visually-observed patterns and reveal relative changes in fluorophores intensity. Differences in DOM origin and composition between land-use types, depths and organic matter pools will be shown by indices calculated using the fluorophores intensities. The analyzed DOM samples were collected at the end of the dry season. Because the DOM samples collected during the whole year are still available, further analysis could be done to reveal changes in DOM origin and composition between rainy and dry seasons. 


\subsubsection{Rock-Eval pyrolysis}

\section{Objectives and methods}

The RE pyrolysis originally was developed for petroleum exploration, but was successfully used to assess the dynamic of organic matter humification in soil (Disnar et al., 2003). RE pyrolysis consists of a first phase where samples are pyrolysed under inert atmosphere (up to $650{ }^{\circ} \mathrm{C}$ ). The residual carbon is subsequently burnt in an oxidation oven (up to $850{ }^{\circ} \mathrm{C}$ ). The instrument measures continuously the hydrocarbons (HC) released during pyrolysis by flame ionization, and the $\mathrm{CO}$ and $\mathrm{CO}_{2}$ produced by infrared. Various parameters characterizing SOM are extracted from these measurements:

- $\quad$ Total organic C: addition of (1) the hydrocarbon compounds released during pyrolysis, (2) the $\mathrm{CO}$ released during pyrolysis up to $500^{\circ} \mathrm{C}$ and (3) the $\mathrm{CO}_{2}$ released during pyrolysis up to $400^{\circ} \mathrm{C}$

- Mineral C: addition of the $\mathrm{CO}_{2}$ released during pyrolysis above $400^{\circ} \mathrm{C}$ and the $\mathrm{CO}_{2}$ from carbonate decomposition during the oxidation phase from $650^{\circ} \mathrm{C}$ to $850^{\circ} \mathrm{C}$

- $\quad$ Tmax: Temperature which corresponds to the maximum release of hydrocarbons during pyrolysis

- $\quad$ Hydrogen index (HI): quantity of HC released during pyrolysis relative to TOC (mg HC $\mathrm{g}^{-1}$ TOC)

- Oxygen index (OI): quantity of oxygen released as $\mathrm{CO}$ and $\mathrm{CO}_{2}$ during pyrolysis, relative to TOC ( $\left.\mathrm{mg} \mathrm{O}_{2} \mathrm{~g}^{-1} \mathrm{TOC}\right)$

$\mathrm{HI}$ and $\mathrm{OI}$ are correlated with the elemental ratios $\mathrm{H} / \mathrm{C}$ and $\mathrm{O} / \mathrm{C}$, respectively. Therefore, they are used as "pseudo" Van Krevelen diagrams to assess the maturity (humification) of SOM. Tmax is also an indicator of the SOM maturity. In contrast to organic carbon in rocks where the release of $\mathrm{HC}$ follows a normal distribution with temperature, the release of HC from SOM shows various peaks due to the diversity of SOM fractions which are at different degrees of humification. The signal of the pyrolized HC is analyzed by peak deconvolution or by integration of the signal between fixed temperatures (Disnar et al., 2003; Sebag et al., 2006). Two indices were built to 
reflect the degree of some decomposition: 1) the I-index which is the logarithm of the ratio of the percentage of $\mathrm{HC}$ released from $250{ }^{\circ} \mathrm{C}$ to $400{ }^{\circ} \mathrm{C}$ (labile SOM) to the percentage of $\mathrm{HC}$ released from $400{ }^{\circ} \mathrm{C}$ to $460{ }^{\circ} \mathrm{C}$ (humified SOM); higher values correspond to higher SOM lability, and 2) the R-index which is the percentage of $\mathrm{HC}$ released from $400{ }^{\circ} \mathrm{C}$ to $600^{\circ} \mathrm{C}$; higher values correspond to higher stabilization. Both indices were correlated to SOM composition determined by NMR techniques (Albrecht et al., 2014); I-index with easily degradable components (alkyl C et O-alkyl C), and R-index with phenolic and aromatic C.

The measurements of Ah horizons from the four land-use types in both regions and the subsoil samples from Harapan region have been done. Samples were oven-dried $\left(105{ }^{\circ} \mathrm{C}\right)$ and grinded before analysis. The calculation of the I- and R-index is finished.

\section{Results and discussion}

A principal component analysis performed with the Ah horizons in Harapan showed a clear separation between forest and plantations (Fig. 4-6).
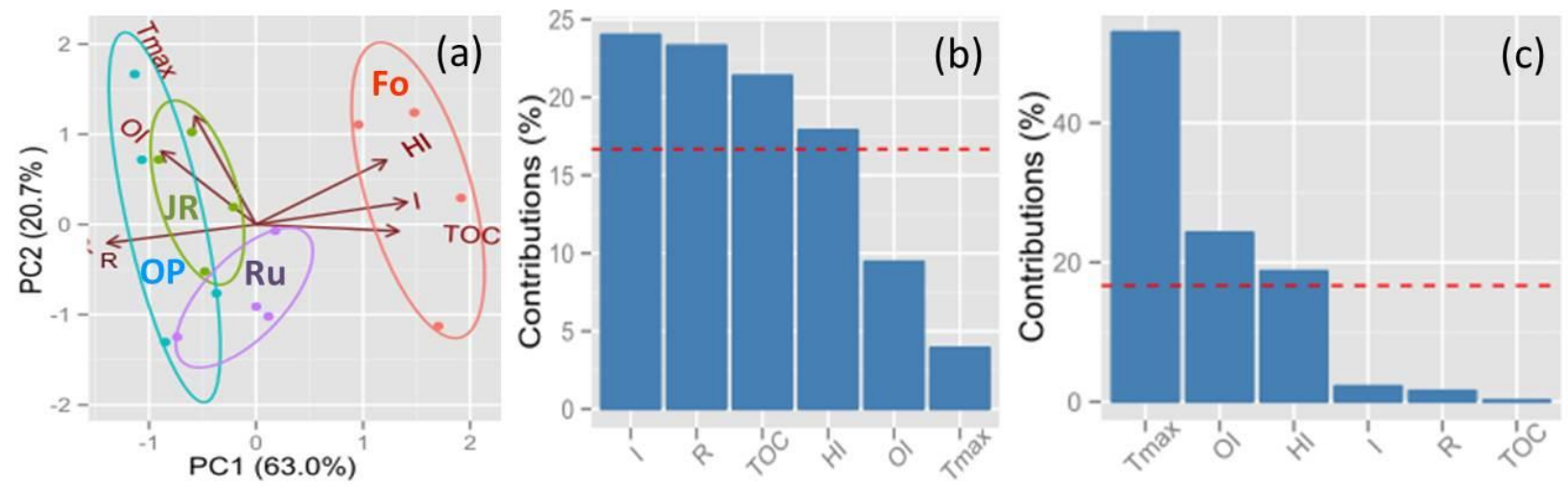

Figure 4-6: Principal component analysis on the Ah horizon from the four land-use types in Harapan region separated by variables obtained from the RE pyrolysis.

(a) Biplot of the total organic carbon (TOC), hydrogen index (HI), oxygen index (OI), the temperature corresponding to the maximum release of hydrocarbons (Tmax), the I-index (I) and the R-index (R) measured by RE pyrolysis. (B) Variables contribution to the first component. The red dotted-line indicates the contribution if all variables would contribute similarly to the component. (C) Variables contribution to the second component.

The first component indicated that the soils under forest have higher TOC and a higher proportion of labile SOM (higher HI and I-index) than under plantations. Plantations were poorly separated by these variables, although oil palms tended to have less TOC and more stable SOM (lower R-index and higher I-index) than jungle rubber and rubber plantations. Tmax contributed 
to half of the variance explained by the second component; the remaining contribution came from the elemental ratio between $\mathrm{C}, \mathrm{O}$ and $\mathrm{H}$ (OI and $\mathrm{HI}$ index). While the second component separated the replicate sites of oil palm and forest, it separated jungle rubber from rubber plantations. The interpretation of the second component requires further data processing and literature research because various factors influence Tmax (e.g. interactions with SOM and mineral matrix) and different decomposition processes affect the $\mathrm{C} / \mathrm{O}$ and $\mathrm{C} / \mathrm{H}$ ratios differently. Nevertheless, it suggests that SOM under jungle rubber was more humified than under rubber plantations. Because SOC pools were bigger and older under jungle rubber, the proportion of fresh $\mathrm{C}$ input from leaves and roots in the SOM could be lower under jungle rubber than rubber plantations. Consequently, SOM under rubber plantations would on average more available under rubber compared to jungle rubber. 


\subsection{Study 5}

\section{Microbial response to easily available $\mathbf{C}$ input}

In study 3, we published only a subset of the dataset produced during the incubation experiment. The goal of study 3 was to assess the sensitivity of various indicators of microbial activity. Nevertheless, we produced further data reflecting the impact of land-use changes on microbial activity.

In total, the incubation experiment lasted 156 days and was divided in three phases with various treatments (Fig. 4-7)

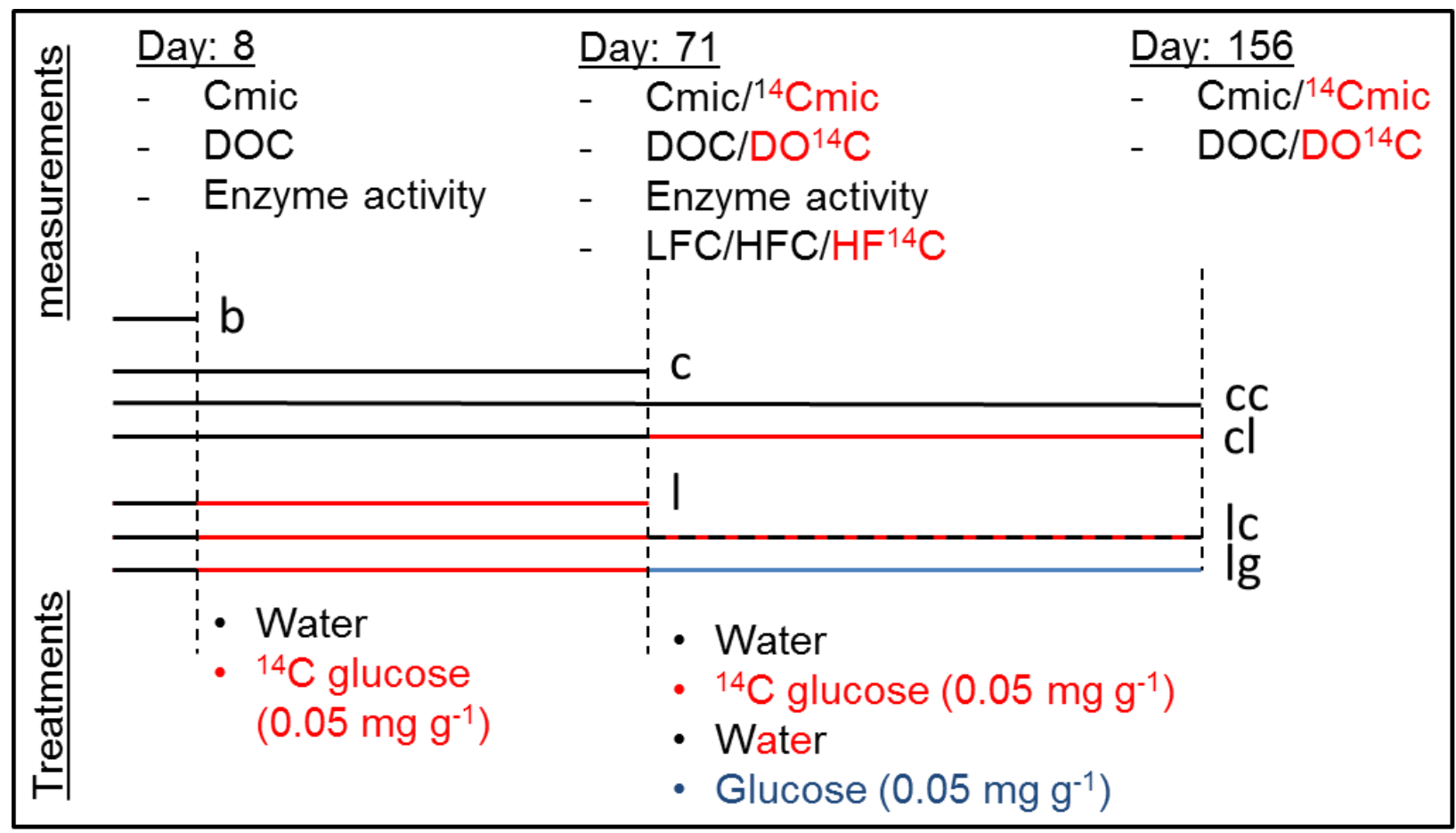

Figure 4-7: Experimental design of the incubation, describing the treatments and measurements done at three time points.

Each line represents one of the seven laboratory replicates used for each Ah horizons from Harapan region; b: baseline parameters, c: control, l: ${ }^{14} \mathrm{C}$ labelled-glucose, g: glucose

1. Pre-incubation (day: 0-8)

2. ${ }^{14} \mathrm{C}$ glucose labelling experiment under the initial soil condition (day: 8-71): The goal was to assess $\mathrm{C}$ allocation to different $\mathrm{SOM}$ pools: $\left(\mathrm{CO}_{2}, \mathrm{Cmic}\right.$, DOC, light fraction, heavy fraction) 
3. $\quad{ }^{14} \mathrm{C}$ glucose labelling experiment under starving condition (day: 70-156): The goal was to assess the substrate induced respiration (SIR) and priming effect after the decomposition of the initial easily available $\mathrm{C}$.

The amount of added glucose was low $\left(0.05 \mathrm{mg}_{\text {glucose }} \mathrm{g}^{-1}\right.$ of dried soil with an activity of 3751 and $4906 \mathrm{~Bq}$ for the $1^{\text {st }}$ and $2^{\text {nd }}$ addition, respectively) in order to avoid activation of dormant microorganisms (Blagodatskaya \& Kuzyakov, 2013). For the $2{ }^{\text {nd }}$ phase, ${ }^{14} \mathrm{C}$-labelled glucose was added in three replicates using $1 \mathrm{ml}$ of the solution (Fig. 4-7). Three replicates were used as control $\left(1 \mathrm{ml}\right.$ deionized water). The last subsample was used for destructive analysis. For the $3^{\text {rd }}$ phase, two control replicates of the $2^{\text {nd }}$ phase received ${ }^{14} \mathrm{C}$-labelled glucose or deionized water. Two labelled replicates of the $2^{\text {nd }}$ phase received glucose or deionized water. The remaining replicates were used for further destructive analysis. The goal of the treatment with glucose addition in previously labelled samples was to assess differences in priming effect between the old (SOM) and new (glucose from the $1^{\text {st }}$ addition) $\mathrm{C}$ stabilized in the SOM.

Details on the incubation experiment and measurements of $\mathrm{CO}_{2}$, microbial biomass (Cmic), $\mathrm{K}_{2} \mathrm{SO}_{4}$-extractable dissolved organic carbon (DOC), enzyme activities ( $\beta$-glucosidase, $\beta$ cellobiohydrolase, $\beta$-xylosidase and acid phosphates) and density fractionation are given in the method section of the $3^{\text {rd }}$ study. ${ }^{14} \mathrm{C}-\mathrm{CO}_{2}$ was measured by liquid scintillation counting (Beckman LS 6500, Beckman Instrument, USA). $0.5 \mathrm{ml}$ of the trapping solution and $2.5 \mathrm{ml}$ of LSC-universalcocktail (Rotiszint ${ }^{\circledR}$ eco plus) were thoroughly mixed and left overnight before measurement to avoid scintillation artifacts. The same procedure was used to measure ${ }^{14} \mathrm{C}$ in Cmic, DOC and the $\mathrm{C}$ dissolved during the density fractionation (dfDOC).

\section{Results and discussion}

The results of the soil pre-incubation have to be interpreted with care. Indeed, there are interactions between the original effect of land-use types on SOM availability and microbial communities, as well as the effects of the sample preparation and the soil rewetting. For instance, forest soils with high SOM content might be more hydrophobic than plantation soils, resulting in a longer time lag before water reaches small pores. Nevertheless, the respiration rates showed an interesting pattern between land-use types during the first 5 days (Fig. 4-8). 


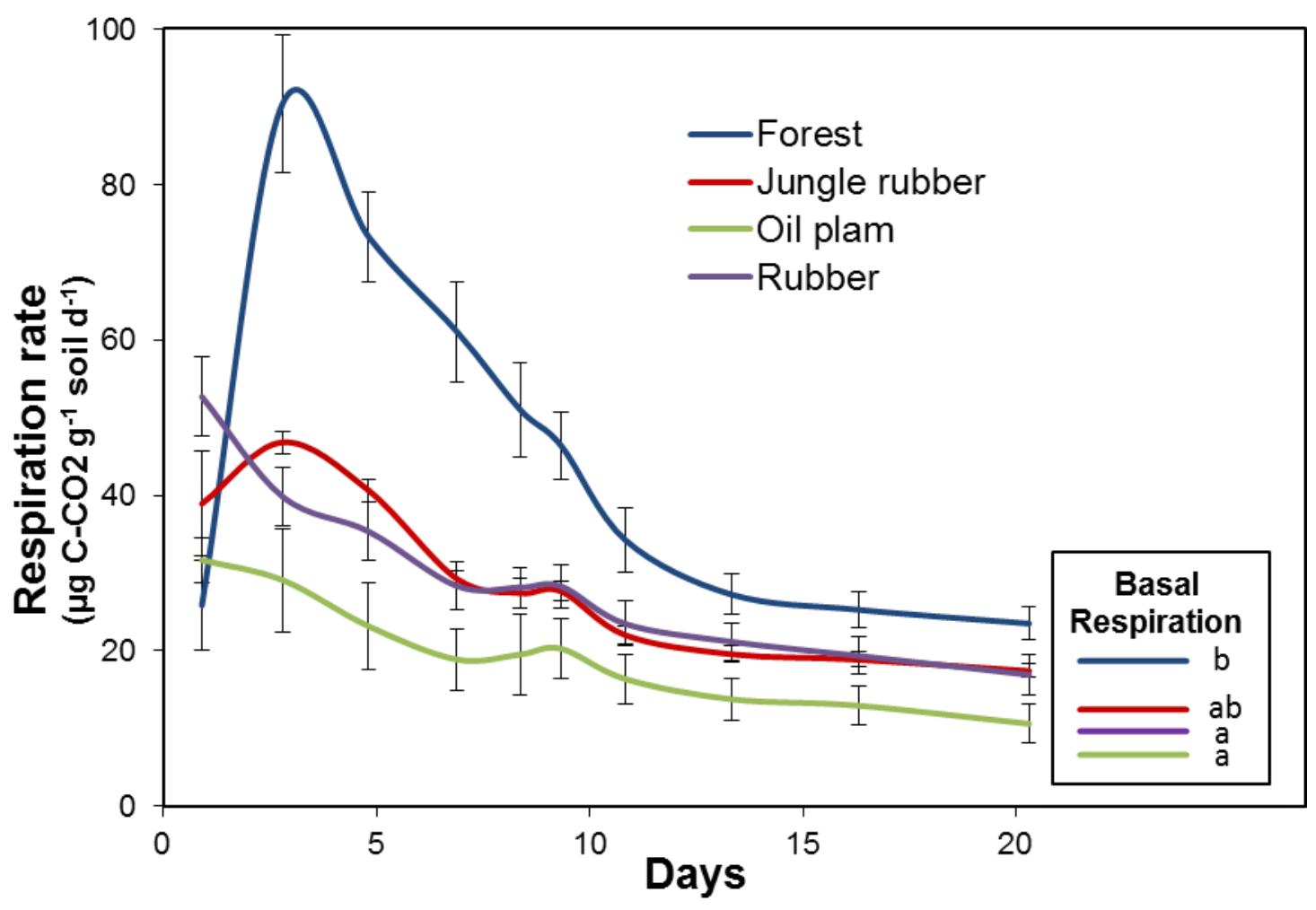

Figure 4-8: Respiration rates during the first 20 days of soil incubation. Error bars represent the standard error calculated on the average of four field replicates. Averages of the field replicates were calculated using six laboratory replicates per single field replicates.

While the microbial respiration under rubber and oil palm reached their maximum within the first two days, jungle rubber and forest reached their maximum within days 2-4. During the first two days, the respiration rates were lowest for forest and highest for rubber plantations. This suggests a time lag in the reactivation of microorganisms depending on the land-use type.

Recent studies have found that soil rewetting resulted in two main patterns: highest respiration rate 1) directly upon rewetting or 2) after a time lag (Meisner et al., 2013). The time lag depended on the duration of the soil drying, but also on the soil condition before the dryingrewetting event; the longer the soil was wet before a drying-rewetting event, the longer the time lag (Meisner et al., 2015). Drying-rewetting events are common under oil palm and rubber plantations because the canopy is not closed and the litter layer is thin or absent. Consequently, the microclimate under the canopy of intensive plantation is less buffered than under forest and jungle rubber. Therefore, microorganisms under intensive plantations would be better adapted to such conditions and react quickly to the return of favorable conditions. To test this hypothesis, a higher time-resolution of measurements during the pre-incubation is needed to ensure that these 
patterns were no artifacts due to the low time resolution. Indeed, it is necessary to have at least two measurement points before microorganisms reach their highest respiration rate. Then, multiple drying-rewetting events during soil incubation should turn the microbial reactivation under forest (type 2: time lag) into a reactivation similar to pattern observed under intensive plantation (type 1: direct)

\section{C allocation}

The preliminary results from the second phase showed an effect of land-use type in the ${ }^{14} \mathrm{C}$ allocation between pools (Fig. 4-9).

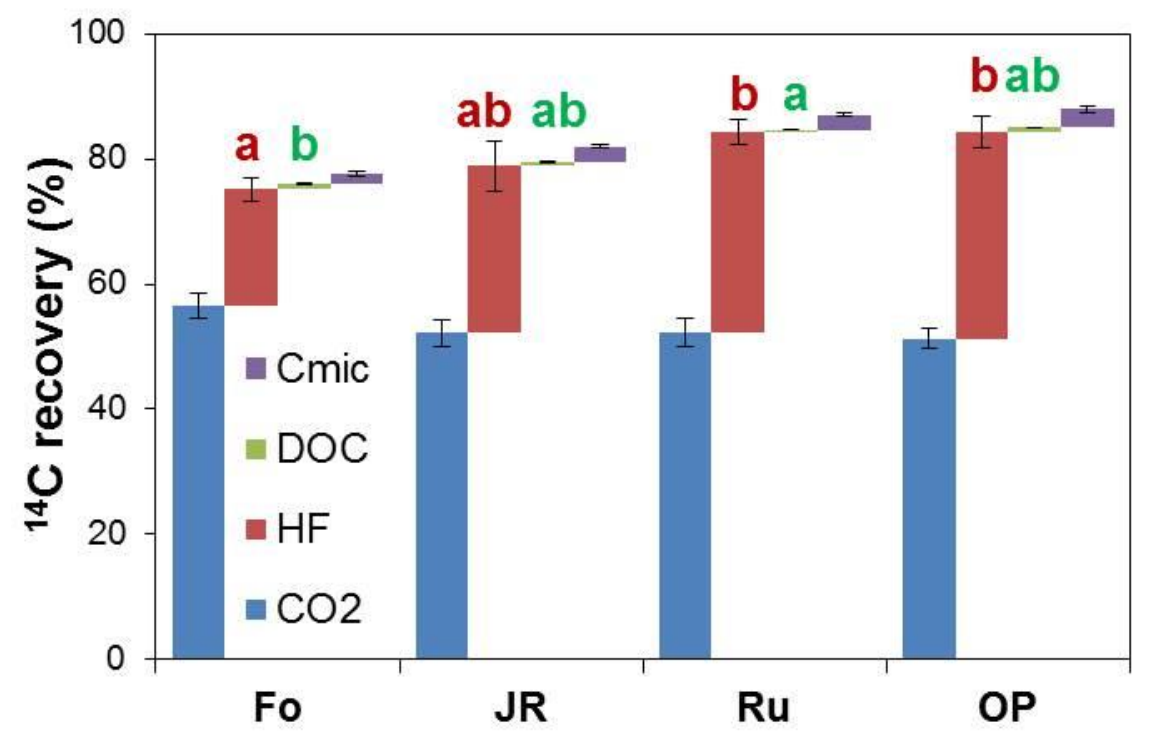

Figure 4-9: Recovery of ${ }^{14} \mathrm{C}$ in SOM pools.

Percentage of ${ }^{14} \mathrm{C}$ recovery after 63 days (first addition) in the $\mathrm{CO}$ 2, heavy fraction (HF), $\mathrm{K}_{2} \mathrm{SO}_{4}$-extractable DOC (DOC) and microbial biomass under forest (Fo), jungle rubber (JR), rubber (Ru) and oil palm (OP). Different letters represent significant differences in the recovery of a single pool between land-use types (ANOVA, $\mathrm{p}<0.05$ ).

The stabilization of glucose-derived $\mathrm{C}$ in the heavy fraction was lowest under forest and highest under intensive plantations. Surprisingly, the opposite was observed for the recovery in the DOC pool. This suggests that glucose-derived C was integrated in more labile SOM pools under forest than under plantations. The ${ }^{14} \mathrm{C}$ recovery in $\mathrm{LF}$ is not measured yet, but samples are still available. This measurement should confirm or infirm this hypothesis. Further, the total ${ }^{14} \mathrm{C}$ recovery was slightly lower under forest (78\%) than under plantations (81 to 88\%). Because the LF pool was larger under forest, the difference in recovery might be explained by the ${ }^{14} \mathrm{C}$ 
stabilized in this pool. Finally, the respired ${ }^{14} \mathrm{CO}_{2}$ was higher and ${ }^{14} \mathrm{Cmic}$ incorporation lower under forest than under plantations. The differences, however, were not significant. In summary, the amount of glucose-derived C retained in the microbial biomass or the SOM tend to be higher under intensive plantations. Furthermore, it was incorporated in $\mathrm{C}$ pools with higher stability.

\section{Substrate induced respiration}

The SIR was calculated for the 24 hours following the substrate addition (Fig. 4-10).

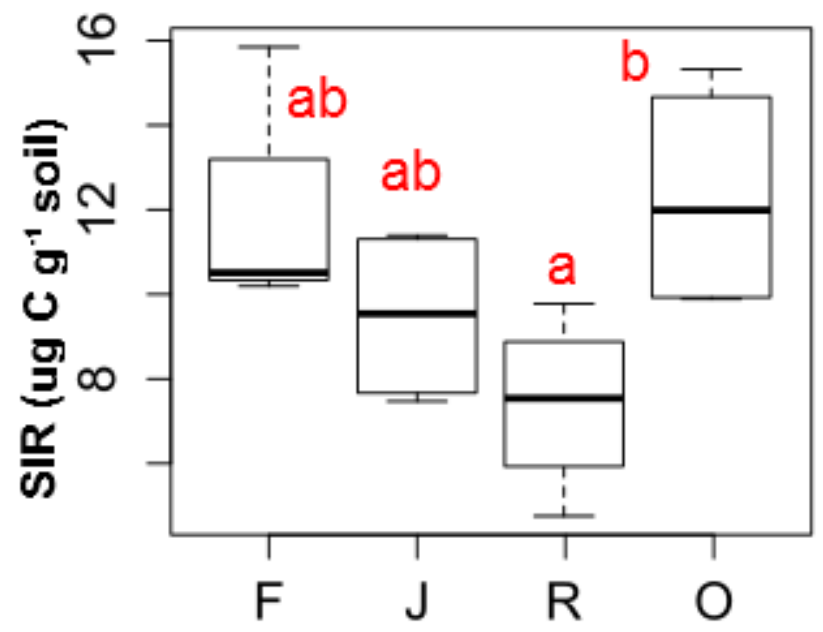

Figure 4-10: Substrate induced respiration (cumulative C-C02) during 24 hours after substrate addition.

The SIR was significantly higher under oil palm than under rubber plantations due to a lower apparent priming effect under rubber plantations. Indeed, the C-use efficiency (CUE) of the added glucose was similar under all plantations during the first 24 hours, 25 to $27 \%$ of added ${ }^{14} \mathrm{C}$ were respired during this period, and slightly more under forest (30\%).

A lower proportion of the glucose-derived $C$ was respired after the $2^{\text {nd }}$ addition (36 to $40 \%$ during 67 days) compared to the $1^{\text {st }}$ addition (51 to 56\% during 63 days). The apparent higher microbial CUE was increased and can be explained by a higher scarcity of easily available C after 71 days of incubation than after 8 days of incubation, as illustrated by a decrease of DOC from 8 to 71 days (Fig. 4-11). 


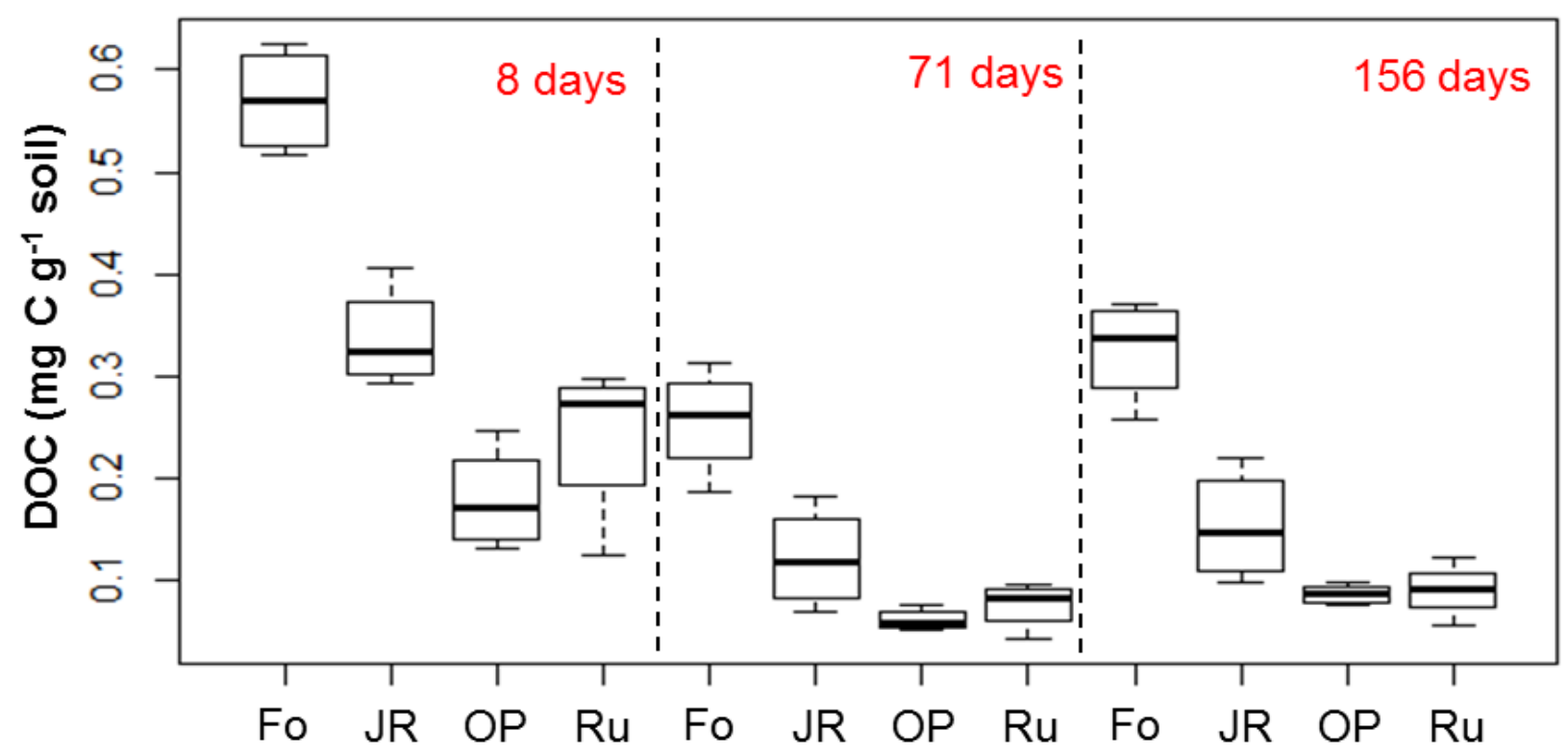

Figure 4-11: $\mathrm{K}_{2} \mathrm{SO}_{4}$-extractable DOC after 8, 71 and 156 days of incubation of soils under forest (Fo), jungle rubber $(\mathrm{JR})$, oil palm $(\mathrm{OP})$ and rubber $(\mathrm{Ru})$ plantations.

In summary, the effect of the land-use type on microbial activity was strong. Furthermore, differences between oil palm and rubber plantations were observed, for instance, on SIR. However, the data processing has to be continued to allow a clear interpretation of the results. For instance, calculations of the relative ${ }^{14} \mathrm{C}$ activity (per $\mu \mathrm{g} \mathrm{C}$ ) in various pools are not done yet, and may show stronger effects between land-use types. Further, the comparison between the $1^{\text {st }}$ and $2^{\text {nd }}$ addition is not finished. The parameters describing enzyme activity (Vmax and $\mathrm{Km}$ ) are calculated but not interpreted yet. Finally, further measurement of ${ }^{14} \mathrm{C}$ on solid samples should be performed on the LF and the bulk soil to assess if the missing ${ }^{14} \mathrm{C}$ should be attributed to the LF or the $\mathrm{CO}_{2}$ fraction. From these results, we would definitively conclude if the amount of easily available $\mathrm{C}$ stabilized in the soil depends on the land-use type and which processes are involved. 


\subsection{Study 6}

\section{Carbon translocation between topsoil and subsoil by dissolved organic} matter

$\mathrm{C}$ stocks, $\mathrm{C}$ inputs, water cycle and microbial activity are strongly modified by tropical forest conversion, affecting the dissolved organic matter (DOM) production, mineralization and translocation between soil depths. Depending on the interactions between these parameters, changes in DOM leaching could, therefore, decrease or increase the $\mathrm{C}$ sequestrated in plantations subsoil.

\section{Objectives and methods}

The objective of this research was to assess the effect of tropical forest conversion on $\mathrm{C}$ fluxes from the topsoil to the subsoil by DOM leaching. The soil solution was sampled at 15 and $75 \mathrm{~cm}$ depth twice per month over one year (from July 2013 to July 2014) in two replicate sites of each land-use types in the Harapan region. The depths were chosen to collect the soil solution below the Ah horizon $(15 \mathrm{~cm})$ and in the lower part of the Bt horizon $(75 \mathrm{~cm})$. The depth of the $\mathrm{Bt}$ horizon varies between sites. Consequently, we chose to sample at a fixed depth in the Bt horizon to improve the comparison of DOM fluxes between sites. The chosen depth ensured that, in each site, the soil solution was collected above layers presenting stagnic or gleyic properties. In each plot, two ceramic suction cups (maximum pore size $1 \mu \mathrm{m}$ ) per depth were installed. A vacuum of 0.4 bar $(15 \mathrm{~cm})$ and $0.46(75 \mathrm{~cm})$ was applied to have a similar suction force at both depths. Samples were accumulated in the field for two weeks in acid-washed glass bottles. After two weeks, samples were transported to the laboratory, filtered at $0.45 \mu \mathrm{m}$ and directly frozen until DOC and DON measurements (Multi N/C 21002, Analytik Jena) in Germany. All DOC and DON measurement are finished and samples are stored frozen.

\section{Results and discussion}

The preliminary results showed that land-use type had no effect on the DOC concentration (yearly average) under the Ah horizon. The concentration was slightly higher under jungle rubber but it was associated with high variability (Fig. 4.12). While the DOC concentration was 
slightly lower in the subsoil than in the topsoil in all other land-use types, it was surprisingly higher in the subsoil under oil palms.

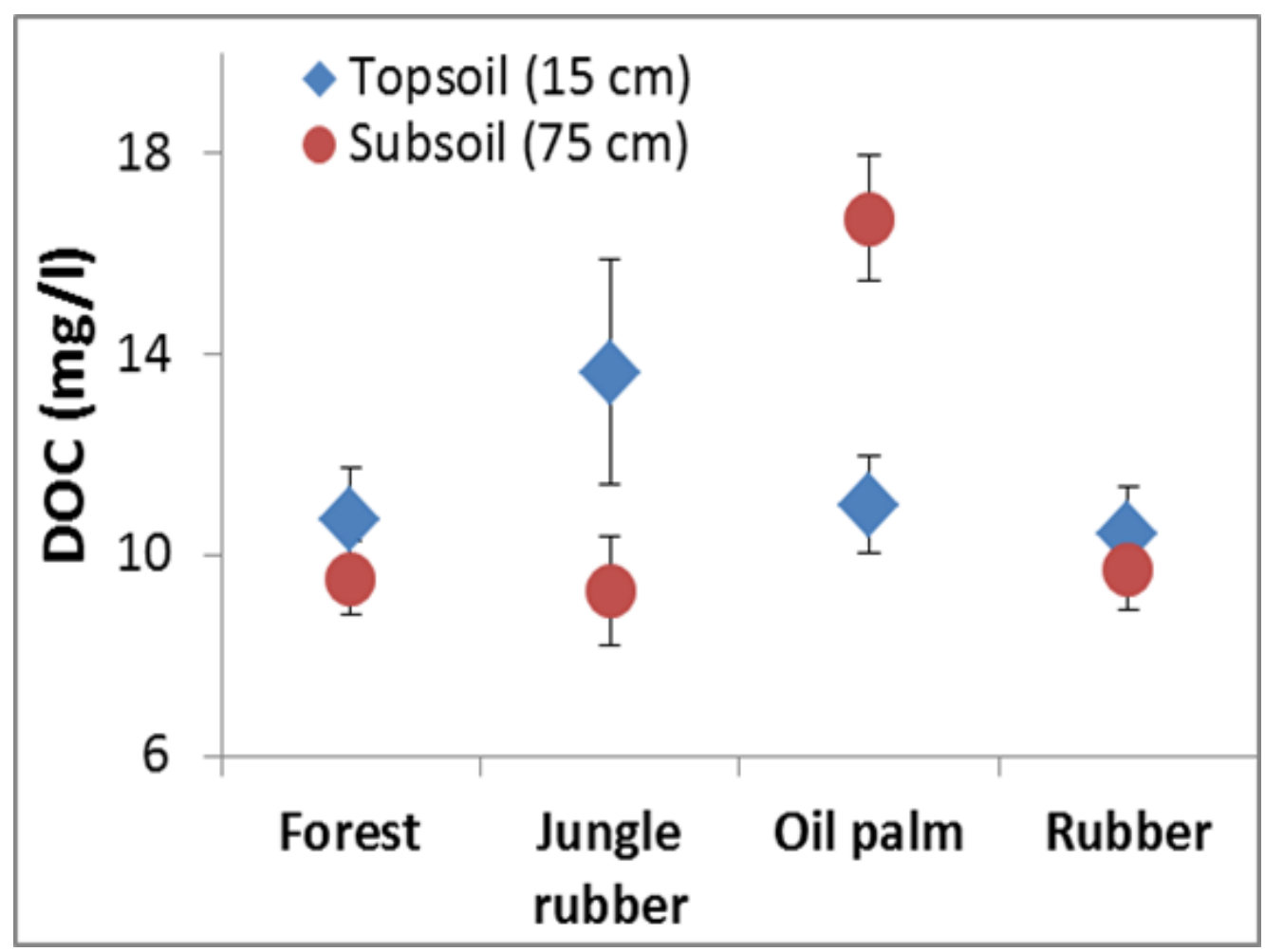

Figure 4-12: Yearly average of DOC concentration in the top soil and subsoil under forest, jungle rubber, rubber and oil palm plantations.

This suggests a high DOC production between 15 and $75 \mathrm{~cm}$ depth under oil palm. Oil palms have a dense rooting zone down to $30 \mathrm{~cm}$ that could be the source of DOC under $15 \mathrm{~cm}$ depth. We will use the water flow modelling made by the subproject A05, but not published yet, to assess if the differences in concentration reflect differences in $\mathrm{C}$ fluxes. Their preliminary results showed also higher DOC leaching at $1.5 \mathrm{~m}$ depth under oil palm plantations. Furthermore, we will use the results from the 3D fluorescence to disentangle the DOC sources, i.e. microbialderived compound or SOM product from enzymatic reactions. This should reflect changes in microbial carbon-use efficiency of root-derived $\mathrm{C}$. 


\section{Synthesis}

\subsection{SOC losses}

\section{Relevance of SOC losses}

The maximum SOC losses after forest conversion to plantations reached $13 \mathrm{Mg} \mathrm{Cha}^{-1}$ under the oil palm plantations in Harapan region. Not all SOC losses were necessarily emitted as $\mathrm{CO}_{2}$ as carbon can be lost through erosion and may be partly stored in lower landscape positions (Berhe et al., 2007). Nonetheless, SOC losses contribute to greenhouse gas emissions and should be accounted when budgeting GHGE from forest conversion to plantations. The contribution of soils to $\mathrm{CO}_{2}$ emissions, however, was low compared to the contribution from plant biomass losses (Fig. 5-1).

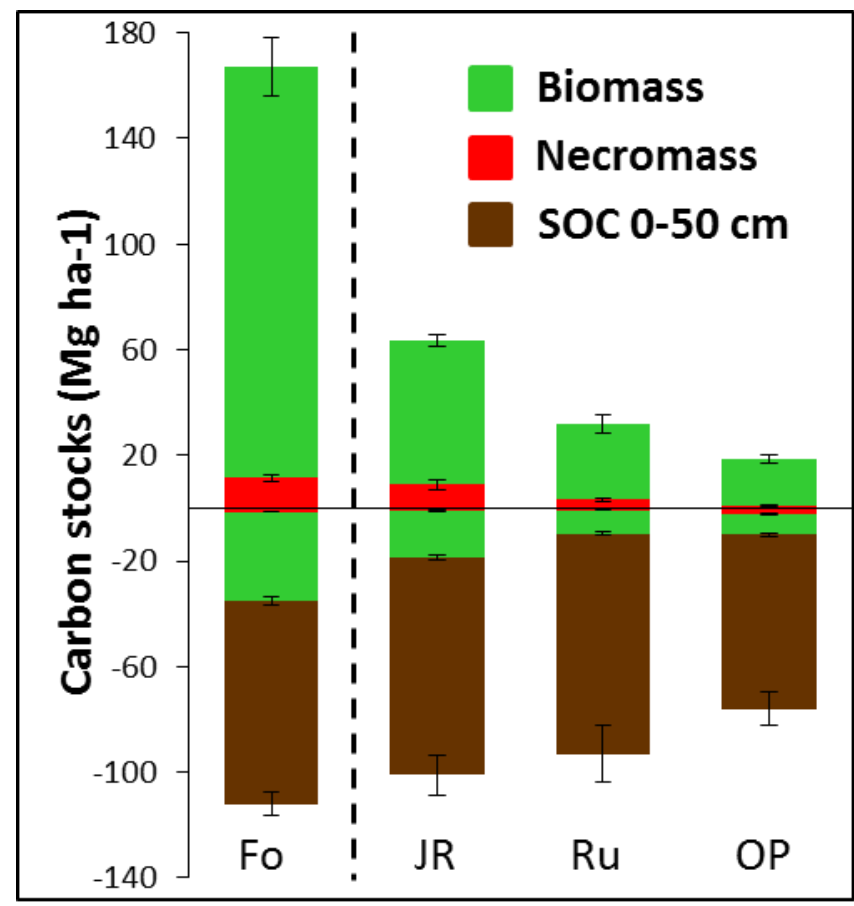

Figure 5-1: Aboveground and belowground carbon stocks in forest (Fo), jungle rubber (JR), rubber (R) and oil palm (OP) plantations. 
Mean \pm SE $(n=8)$. Negative values represent belowground C stocks. Stocks: Aboveground biomass, dead wood, coarse and fine roots and root necromass (Kotowska et al., 2015); litter (Krashevska et al., 2015); SOC 0-50 cm (Guillaume et al., 2015).

Indeed, SOC losses represented at most $7 \%$ of the total $\mathrm{C}$ losses in oil palm plantations. Furthermore, they contributed only about one third of the belowground C losses. For instance, the coarse root biomass decreased strongly in intensive plantations. The dynamic of $\mathrm{C}$ losses is different between the plant biomass and the SOC. On one hand, the biomass is a $\mathrm{C}$ source during the plantation establishment, whereas it acts as a $\mathrm{C}$ sink during the plantation maturation. On the other hand, the SOC is a long term C source because SOC losses continue during the plantation maturation. Consequently, the relative contribution of SOC to the total C losses increases during the plantation maturation.

At the beginning of the project, we hypothesized that the forest conversion leads to an increase of DOC leaching which correspondingly increases the subsoil carbon storage. Nevertheless, despite measuring an increase in DOC leaching under oil palm, we did not observe an increase in SOC stocks in the subsoil, possibly because the plantations were still too young ( $<17$ years old). However, the subproject A05 observed also an increase of DOC leaching at $1.5 \mathrm{~m}$ depth under oil palm, suggesting that the leached DOC did not accumulate at intermediate soil depths. Recent studies have found significant SOC losses in the subsoil of older plantations (Chiti et al., 2014; van Straaten et al., 2015), contradicting the hypothesis of $\mathrm{C}$ accumulation in the subsoil. Therefore, the subsoil SOC pool could experience the most C losses in older plantations. In summary, the $\mathrm{CO}_{2}$ emissions from mineral soils after tropical forest conversion to plantations are small compared to the $\mathrm{CO}_{2}$ emissions from the biomass. Even if the process rates involved in $\mathrm{C}$ and nutrient cycles are faster in the tropics, it still takes decades to observe a significant decrease of the $\mathrm{C}$ sequestrated in the subsoil, while it takes just hours to burn the $155 \mathrm{Mg} \mathrm{C} \mathrm{ha}^{-1}$ that are stored in the aboveground biomass of tropical forests. In conclusion, the contribution of tropical mineral soil to GHGE following deforestation is relatively low compared to the contribution of the vegetation. Nevertheless, the observed trend of establishing new plantations on soils with high $\mathrm{C}$ content indicates that the soils contribution to GHGE is increasing. 


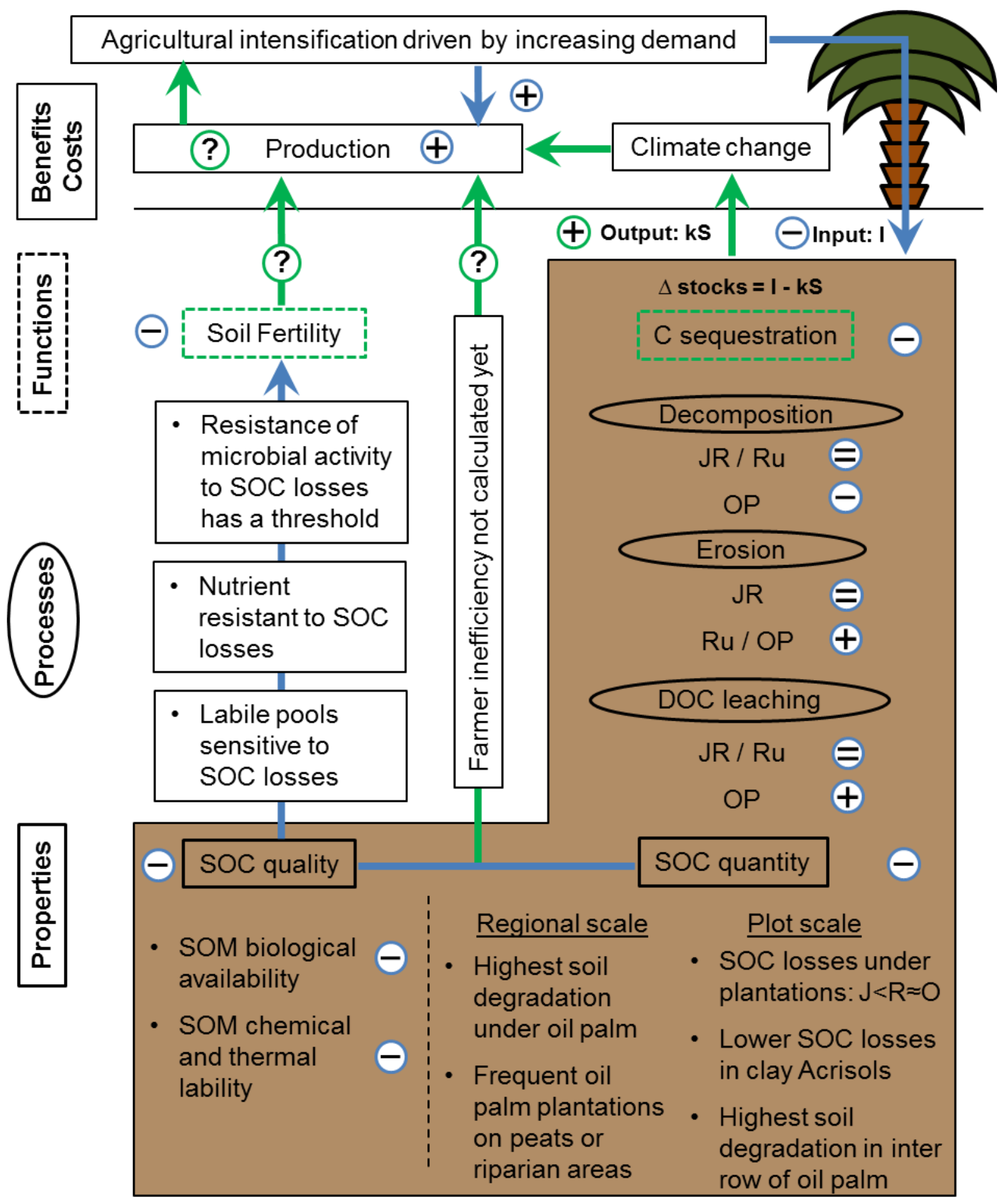

Figure 5-2: Synthesis of the main findings 


\section{Scaling SOC losses up to the landscape level}

Soil samples were collected in one pit at the midpoint of four trees in the interrows and in the landscape position representative of the plot. This sampling design can be associated to a stratified design were the SOC losses in the main stratum, in terms of area, were quantified. According to the study 1, the sampling location only affected SOC losses in oil palm plantations. Differences in SOC losses between sampling locations associated with the respective area of the locations could be used to increase the accuracy of SOC losses quantification at the plantation scale. Further measurements should be done under oil palm frond and roads. Nevertheless, the differences in SOC stocks in the top $5 \mathrm{~cm}$ between locations were not larger than $12 \%$; the depth where SOC losses were largest. A similar study conducted in the region used a different measurement approach, where soil samples were collected at 12 randomly-selected points in a 20 x $20 \mathrm{~m}$ plot (van Straaten et al., 2015). In total, they compared 11 oil palm and 16 rubber plantations to paired forest references located on similar landscape positions. Despite differences in sampling design and sites, both studies measured significant SOC losses only in the top $10 \mathrm{~cm}$ of soil. Further, SOC losses estimated under oil palms differed only of $1 \mathrm{Mg} \mathrm{C}^{-1}$ between both studies, supporting the observation that the differences in SOC losses resulting from the plantation structure were low under oil palms. In our study, SOC losses under rubber plantations, however, were $7 \mathrm{Mg} \mathrm{C} \mathrm{ha}^{-1}$ higher compared to the study of van Straaten et al. (2015). This is explained by the fact that the $\mathrm{C}$ contents in our rubber sites ( $2.6 \% \mathrm{C}$ in the Ah horizon) was in the low range of $\mathrm{C}$ contents found under rubber plantations in the province (median; $3.7 \% \mathrm{C}$ ). In contrast, the $\mathrm{C}$ content under oil palm $(2.1 \% \mathrm{C})$ was similar to the median of $\mathrm{C}$ contents under oil palm plantations in the province $(2.2 \% \mathrm{C})$.

In order to scale up SOC losses after forest conversion, at least two more factors should be taken into account. First, the soil type and/or the clay content are known to influence SOC losses after land-use changes (Powers et al., 2011). Higher clay content reduced SOC losses after forest conversion to oil palm and rubber plantations in Jambi province (van Straaten et al., 2015). This trend was observed in our study sites where we measured higher $\mathrm{C}$ contents in the clay Acrisols (Bukit) than in the loam Acrisols (Harapan) sites. Secondly, the landscape position has a strong impact on SOC stocks because of the high erosion and the frequent occurrence of riparian areas with high SOC in the lower landscape positions. The landscape position explained the high 
variability within plot observed by the subproject A05 in our study plots (Kara Allen and Marife Corre, personal communication). Because of the large plot dimensions (50 x $50 \mathrm{~m})$, the frequent slope changes in Jambi landscape and the small size of smallholder's plantations (2-3 ha), it was difficult to establish plots in homogenous landscape positions. As a result, all plots were a mixture of various landscape positions which include riparian areas. Therefore, the variability between land uses was much smaller than the variability within or between plots. In a random sampling design, the plot number should be increased to observe a significant effect of the landuse type. The landscape position should be included in a stratified design. In fact, SOC stocks differences depending on the landscape position (summit, upper slope, middle slope, lower slope and bottom) were measured in an oil palm plantation (PTPN6) in collaboration of the project A03. Finally, because oil palm plantations are frequently established in riparian areas (study 1), they should be included for scaling SOC losses up to the landscape scale.

Nonetheless, study 1 showed that it is not sufficient to assess SOC losses resulting from agricultural intensification by considering only the losses from forest conversion to plantations. Under conditions of land resources scarcity, sites history is more complex than a direct conversion from primary forest to plantations, and affects SOC losses differently. The dynamic of SOC stocks changes depending on the plantation age was assessed in recent studies (de Blécourt et al., 2013; van Straaten et al., 2015). However, there is a lack of information on the impact of different conversion pathways on SOC stock dynamics (e.g. secondary forest to fallow land to intensive plantation or re-establishment of oil palm plantations). Especially, the method and number of land-clearing events are important factors because of the high soil erosion associated with these events. In summary, up-scaling SOC losses at the landscape level remains a complex challenge. Nevertheless, a stratified model including the effect of plantation structure under oil palms, landscape position, clay content, age of the plantations and the number of clearing events should provide accurate results. Because data are already available for the effects of plantation type, structure and age, studies should focus on the effect of landscape position and clearing events. 


\subsection{Soil fertility}

Even though the SOC losses were small in comparison to the C losses from the plant biomass, the impacts on soil functioning were strong. Three measurements of microbial activity (basal respiration, microbial biomass and enzyme activity) showed that the microbial activity was lower under plantations compared to forest, indicating a decrease of SOM functions supporting microbial activity. Beside the decrease in quantity, forest conversion to plantations induced a decrease of SOM quality. Each technique used to characterize SOM showed that SOM was in a more advanced stage of decomposition under plantations. The quantity of SOM pools known to be more labile ( $\mathrm{LF}, \mathrm{K}_{2} \mathrm{SO}_{4}$-extractable DOC) was strongly reduced under plantations. Further, the decrease of hydrocarbon released at lower temperature during the pyrolysis can be interpreted as a decrease of SOM labile pools. Higher $\delta^{13} \mathrm{C}$ values in the $\mathrm{Ah}$ horizon under plantations suggest that the organic matter underwent more recycling events between the SOM and the microbial biomass. Indeed, this is the main process leading to ${ }^{13} \mathrm{C}$ enrichment in soil (Werth \& Kuzyakov, 2010; Gunina \& Kuzyakov, 2014). The decreases of H/C and the aliphatic/aromatic ratios indicate a condensation of organic matter and so, a stabilization of organic matter due to humification processes.

Nonetheless, according to the microbial biomass and the basal respiration, the microbial activity was resistant to the decrease of SOC and labile pools, indicating that the SOC availability was not the main limiting factor of microbial activity in all plantation types. Nutrients ( $\mathrm{N}$ and $\mathrm{P}$ ) were resistant to SOC decrease, resulting in a relative nutrient enrichment of SOM. Furthermore, the microbial activity decreased proportionally with the decrease of total nitrogen. This suggests that nutrients play an important role in the plantations to maintain the microbial activity and the functions they provide. Nonetheless, nutrient and $\mathrm{C}$ addition experiments would be necessary to test the factors limiting microbial activity under plantations. It is also possible that the limiting factor depends on the $\mathrm{C}$ content. Because $\mathrm{P}$ is one of the main limiting factors in tropical forests (Cleveland et al., 2006), the resistance of microbial activity at high C content (jungle rubber) could result from the resistance of $\mathrm{P}$ to SOC losses. Because the $\mathrm{N}$ content decreased faster than the available $\mathrm{P}, \mathrm{N}$ could be the limiting factor at medium $\mathrm{C}$ content (rubber). Finally, the $\mathrm{C}$ availability could be the main limiting factor at low $\mathrm{C}$ content (oil palm). 
The resistance of microbial activity to land-use intensification suggests that the functions provided by microorganisms were also resistant to land-use intensification up to a threshold ( $2.7 \% \mathrm{C}$ in our study sites). Nevertheless, it is particularly complex to relate changes in soil properties and processes to changes in functions or ecosystem services. There are three main reasons explaining this complexity: 1) functions depend on more than one soil property and process, 2) soil properties and processes affect generally more than one function and 3) ecosystem services (or benefits) depends on many functions (e.g. plant growth depends on nutrient and water regulating functions). SOC integrates this complexity by being correlated with all soil properties and processes influencing soil fertility. Furthermore, in contrast to parameters related to microbial activity, $\mathrm{C}$ content is a routine measurement that enables building large datasets. Therefore, correlating SOC with yield seems to be the most promising method to quantify the relationship between soil properties and ecosystem services. Study 1 was designed for this purpose. Environmental (study 1) and socio-economic data (yield, plantation and management characteristics) were collected. However, the farmer inefficiency (difference between the maximal potential output according to farmer input and the measured output) is not estimated yet. Once the data will be available, the farmer inefficiency will be correlated with the soil degradation to quantify the cost of soil degradation under oil palm and rubber plantations.

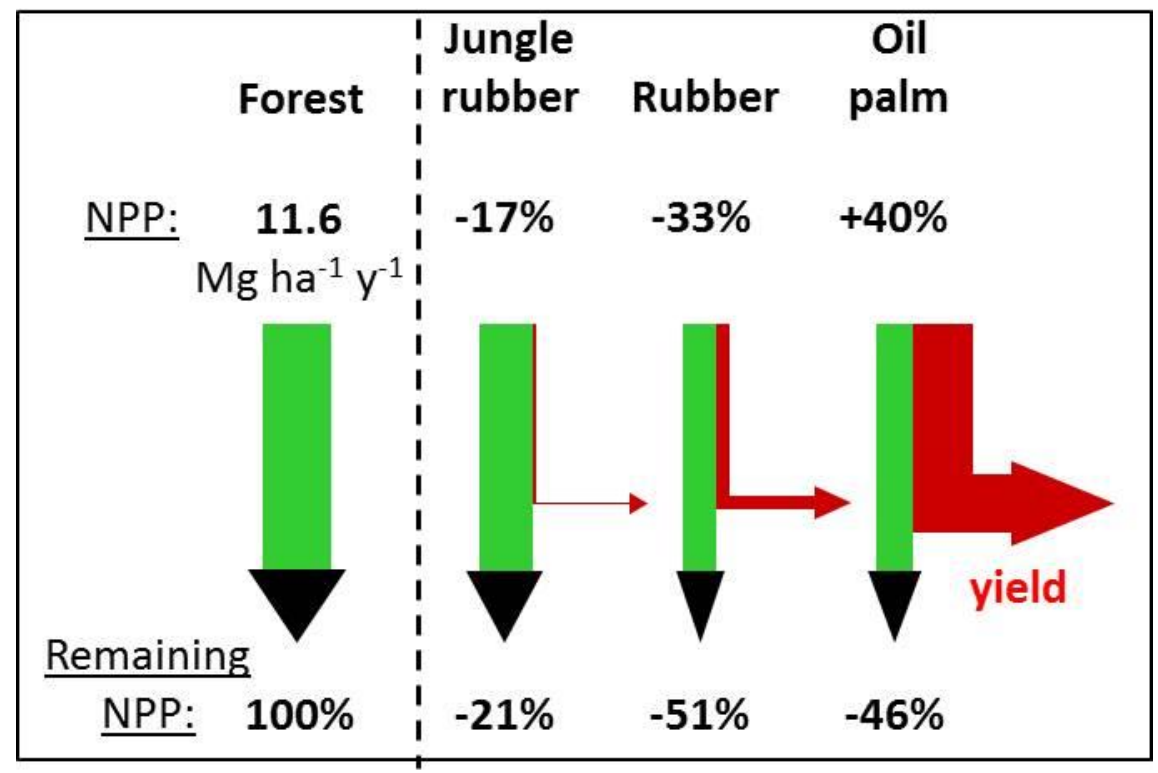

Figure 5-3: Net primary production in the land-use types.

Net primary production (NPP) in forest and relative changes in plantations with and without accounting for the yield (remaining NPP). Data from Kotowska et al. (2015). 


\subsection{Is oil palm the worst?}

This simple question was asked many times during the course of this project by people from various horizons. The thesis presented numerous results on environmental impacts of different plantation types on the soil. Almost without exception, the negative impacts under oil palm plantations were stronger than under jungle rubber and rubber plantations. Nevertheless, the differences were often small and non-significant between the two intensive plantations. Differences in soil erosion or chemical parameters $\left(\mathrm{C}, \mathrm{N}, \mathrm{P}\right.$ contents or $\left.\delta^{13} \mathrm{C}\right)$ were small. Differences in biological parameters (microbial activity) were generally larger, as indicated by a non-linear resistance of these parameters to SOC losses. Accordingly, oil palm plantations had a slightly worse impact on the soil than rubber plantations.

However, the question that should be asked is if oil palm cultivation per se, by the tree physiology or by specific practices that are not separable from its cultivation, is worse than other plantation types. In other terms, if the environmental impacts can be reduced by decreasing the management intensity. At the province level, oil palm cultivation was associated with much stronger negative impacts than rubber. The plantations were more frequently established on soils with high $\mathrm{C}$ content and, on average, the soils showed a critical level of degradation. Nevertheless, this was explained rather by the development of oil palm cultivation in a context of land scarcity then by the type of tree or the management practices. The soil degradation depended on the structure of the plantation under oil palm but not under rubber plantations. This was explained by the absence of aboveground litter resulting in increased erosion and reduced $\mathrm{C}$ input to the soil, especially in the inter rows. The absence of fresh $\mathrm{C}$ input from leaves was also the main factor explaining the lower microbial activity under oil palm plantations. However, the NPP remaining in the plantation after harvesting is similar in both plantation types (Fig. 5-3). Piling the oil palm frond together is a choice of management (better access to the tree, lower risk to be bitten by snakes, etc.) that could be modified. Increasing the groundcover by using the dead fronds or planting a cover crop could improve the soil fertility in oil palm plantations by reducing soil erosion and increasing $\mathrm{C}$ and nutrient input to the soil. However, there is at least one negative aspect that was not studied in this thesis which is inherent to oil palm physiology. Oil palms transpire as much as forest (Röll et al., 2015), leading to a higher risk of water scarcity (Merten et al., under review). Finally, oil palms have to be re-planted more often (every 25-30 
years) than rubber trees (> 40 years). This could be the main negative environmental aspect of oil palm over rubber cultivation. Indeed, the plantation establishment is a critical period associated with strong soil erosion (Gharibreza et al., 2013) in absence of groundcover.

In conclusion, oil palms are the worst for the soil functions not because of the tree itself but because it represents a new type of agricultural intensification in the tropics. Associated to a context of land scarcity, the return on land is achieved not any more by high labor input, like for rubber, but by high fertilizer input, and use of herbicides to save time. Fortunately, this thesis shows that there is room for improving management practices and reducing the environmental impacts of agricultural intensification in the tropics. 


\section{References}

Abood S a., Lee JSH, Burivalova Z, Garcia-Ulloa J, Koh LP (2015) Relative contributions of the logging, fiber, oil palm, and mining industries to forest loss in Indonesia. Conservation Letters, 8, 58-67.

Acton P, Fox J, Campbell E, Rowe H, Wilkinson M (2013) Carbon isotopes for estimating soil decomposition and physical mixing in well-drained forest soils. Journal of Geophysical Research: Biogeosciences, 118, 1532-1545.

Albrecht R, Sebag D, Verrecchia E (2014) Organic matter decomposition: bridging the gap between Rock-Eval pyrolysis and chemical characterization (CPMAS 13C NMR ). Biogeochemistry, 15, 3-4.

Amundson R, Berhe a. a., Hopmans JW, Olson C, Sztein a. E, Sparks DL (2015) Soil and human security in the 21st century. Science, 348, 1261071-1261071.

Andersen CM, Bro R (2003) Practical aspects of PARAFAC modeling of fluorescence excitation-emission data. Journal of Chemometrics, 17, 200-215.

Berhe AA, Harte J, Harden JW, Torn MS (2007) The Significance of the Erosion-induced Terrestrial Carbon Sink. BioScience, 57, 337.

Blagodatskaya E, Kuzyakov Y (2013) Active microorganisms in soil: Critical review of estimation criteria and approaches. Soil Biology and Biochemistry, 67, 192-211.

De Blécourt M, Brumme R, Xu J, Corre MD, Veldkamp E (2013) Soil Carbon Stocks Decrease following Conversion of Secondary Forests to Rubber (Hevea brasiliensis) Plantations. PLoS ONE, 8, e69357.

Bronick CJJ, Lal R (2005) Soil structure and management: A review. Geoderma, 124, 3-22.

Chen W, Westerhoff P, Leenheer J a., Booksh K (2003) Fluorescence Excitation-Emission Matrix Regional Integration to Quantify Spectra for Dissolved Organic Matter.

Environmental Science and Technology, 37, 5701-5710. 
Chiti T, Grieco E, Perugini L, Rey A, Valentini R (2014) Effect of the replacement of tropical forests with tree plantations on soil organic carbon levels in the Jomoro district, Ghana. Plant and Soil, 375, 47-59.

Cleveland CC, Reed SC, Townsend AR (2006) Nutrient regulation of organic matter decomposition in a tropical rain forest. Ecology, 87, 492-503.

Cox L, Celis R, Hermosin MC, Cornejo J, Zsolnay a., Zeller K (2000) Effect of organic amendments on herbicide sorption as related to the nature of the dissolved organic matter. Environmental Science and Technology, 34, 4600-4605.

Demyan MS, Rasche F, Schulz E, Breulmann M, Müller T, Cadisch G (2012) Use of specific peaks obtained by diffuse reflectance Fourier transform mid-infrared spectroscopy to study the composition of organic matter in a Haplic Chernozem. European Journal of Soil Science, 63, 189-199.

Disnar J-R, Guillet B, Kéravis D, Di-Giovanni C, Sebag D (2003) Soil organic matter (SOM) characterization by Rock-Eval pyrolysis: scope and limitations. Organic Geochemistry, 34, 327-343.

Euler M, Schwarze S, Siregar H, Qaim M (2015) Oil palm expansion among smallholder farmers in Sumatra, Indonesia. EFForTS Discussion Paper series 8, Georg-AugustUniversität, Göttingen, Germany.

FAOSTAT (2015) Production / Crops: Oil, palm fruit. http://faostat.fao.org. last accessed in October 2015.

Garnett T, Appleby MC, Balmford a et al. (2013) Sustainable Intensifi cation in Agriculture: Premises and Policies. Science Magazine, 341, 33-34.

Gharibreza M, Raj JK, Yusoff I, Othman Z, Tahir WZWM, Ashraf MA (2013) Land use changes and soil redistribution estimation using 137Cs in the tropical Bera Lake catchment, Malaysia. Soil and Tillage Research, 131, 1-10.

Gibbs HK, Ruesch a S, Achard F, Clayton MK, Holmgren P, Ramankutty N, Foley J a (2010) Tropical forests were the primary sources of new agricultural land in the 1980s and 1990s. Proceedings of the National Academy of Sciences of the United States of America, 107, 16732-16737. 
Guillaume T, Damris M, Kuzyakov Y (2015) Losses of soil carbon by converting tropical forest to plantations: Erosion and decomposition estimated by $\delta 13$ C. Global Change Biology, 21, 3548-3560.

Gunina A, Kuzyakov Y (2014) Pathways of litter C by formation of aggregates and SOM density fractions: Implications from 13C natural abundance. Soil Biology and Biochemistry, 71, 95-104.

Hansen MC, Potapov PV, Moore R, Hancher M, Turubanova SA, Tyukavina A (2013) HighResolution Global Maps of 21st Century Forest Cover Change. Science, 342, 850-853.

Hassouna M, Massiani C, Dudal Y, Pech N, Theraulaz F (2010) Changes in water extractable organic matter (WEOM) in a calcareous soil under field conditions with time and soil depth. Geoderma, 155, 75-85.

Haygarth PM, Ritz K (2009) The future of soils and land use in the UK: Soil systems for the provision of land-based ecosystem services. Land Use Policy, 26, 187-197.

Hsu JH, Lo SL (1999) Chemical and spectroscopic analysis of organic matter transformations during composting of pig manure. Environmental Pollution, 104, 189-196.

Jobbágy EG, Jackson RB (2000) The vertical distribution of soil organic carbon and its relation to climate and vegetation. Ecological Applications, 10, 423-436.

Keating BA, Carberry PS (2010) Sustainable production, food security and supply chain implications. Aspects of Applied Biology, 102, 7-20.

Keating B a., Carberry PS, Bindraban PS, Asseng S, Meinke H, Dixon J (2010) Eco-efficient Agriculture: Concepts, Challenges, and Opportunities. Crop Science, 50, S-109-S-119.

Keating BA, Herrero M, Carberry PS, Gardner J, Cole MB (2014) Food wedges: Framing the global food demand and supply challenge towards 2050. Global Food Security, 3, 125132.

Kotowska MM, Leuschner C, Triadiati T, Meriem S, Hertel D (2015) Quantifying above- and belowground biomass carbon loss with forest conversion in tropical lowlands of Sumatra (Indonesia). Global Change Biology, 10.1111/gcb.12979. 
Krashevska V, Klarner B, Widyastuti R, Maraun M, Scheu S (2015) Impact of tropical lowland rainforest conversion into rubber and oil palm plantations on soil microbial communities. Biology and Fertility of Soils, 51, 697-705.

Lal R (2001) Soil degradation by erosion. Land Degradation \& Development, 12, 519-539.

Lal R (2004) Soil carbon sequestration impacts on global climate change and food security. science, 304, 1623-1627.

Lal R (2006) Enhancing crop yields in the developing countries through restoration of the soil organic carbon pool in agricultural lands. Land Degradation \& Development, 209, 197209.

Lasco RD, Ogle S, Raison J, Verchot L, Wassmann R, Yagi K (2006) Volume 4: Agriculture, Forestry and Other Land Use. In: IPCC Guidelines for National Greenhouse Gas Inventories, Vol. 4, pp. 1-66.

Margenot AJ, Calderón FJ, Bowles TM, Parikh SJ, Jackson LE (2015) Soil Organic Matter Functional Group Composition in Relation to Organic Carbon, Nitrogen, and Phosphorus Fractions in Organically Managed Tomato Fields. Soil Science Society of America Journal, 79, 772 .

Margono BA, Potapov P V., Turubanova S, Stolle F, Hansen MC (2014) Primary forest cover loss in Indonesia over 2000-2012. Nature Climate Change, 4, 730-735.

Meisner A, Bååth E, Rousk J (2013) Microbial growth responses upon rewetting soil dried for four days or one year. Soil Biology and Biochemistry, 66, 188-192.

Meisner A, Rousk J, Bååth E (2015) Prolonged drought changes the bacterial growth response to rewetting. Soil Biology and Biochemistry, 88, 314-322.

Merten J, Röll A, Guillaume T et al. Water scarcity and oil palm expansion: social views and environmental processes. Ecology and Society, under review.

Ohno T (2002) Fluorescence inner-filtering correction for determining the humification index of dissolved organic matter. Environmental science \& technology, 36, 742-746. 
Powers JS, Corre MD, Twine TE, Veldkamp E (2011) Geographic bias of field observations of soil carbon stocks with tropical land-use changes precludes spatial extrapolation. Proceedings of the National Academy of Sciences, 108, 6318-6322.

Röll A, Niu F, Meijide A, Hardanto A, Hendrayanto H, Knohl A, Hölscher D (2015) Transpiration in an oil palm landscape: effects of palm age. Biogeosciences, 12, 1-15.

Schmidt MWI, Torn MS, Abiven S et al. (2011) Persistence of soil organic matter as an ecosystem property. Nature, $\mathbf{4 7 8}, 49-56$.

Sebag D, Disnar JR, Guillet B, Di Giovanni C, Verrecchia EP, Durand A (2006) Monitoring organic matter dynamics in soil profiles by "Rock-Eval pyrolysis": bulk characterization and quantification of degradation. European Journal of Soil Science, 57, 344-355.

Six J, Feller C, Denef K, Ogle SM, de Morales Sa JC, Albrect A (2002) Soil organic matter, biota and aggregation in temperate and tropical soils - Effects of no-tillage. Agronomie, 22, 755-775.

Stevenson JR, Villoria N, Byerlee D, Kelley T, Maredia M (2013) Green Revolution research saved an estimated 18 to 27 million hectares from being brought into agricultural production. Proceedings of the National Academy of Sciences of the United States of America, 110, 8363-8.

Van Straaten O, Corre MD, Wolf K, Tchienkoua M, Cuellar E, Matthews RB, Veldkamp E (2015) Conversion of lowland tropical forests to tree cash crop plantations loses up to onehalf of stored soil organic carbon. Proceedings of the National Academy of Sciences, 112, 9956-9960.

Tarigan SD, Sunarti, Widyaliza S (2015) Expansion of Oil Palm Plantations and Forest Cover Changes in Bungo and Merangin Districts, Jambi Province, Indonesia. Procedia Environmental Sciences, 24, 199-205.

Tilman D, Fargione J, Wolff B et al. (2001) Forecasting agriculturally driven global environmental change. Science, 292, 281-284.

Trumbore SE (1993) Comparison of carbon dynamics in tropical and temperate soils using radiocarbon measurements. Global Biogeochemical Cycles, 7, 275-290. 
Vitousek PM (1984) Litterfall, Nutrient Cycling, and Nutirent Limitation in Tropical Forests. Ecology, 65, 285-298.

Werth M, Kuzyakov Y (2010) 13C fractionation at the root-microorganisms-soil interface: A review and outlook for partitioning studies. Soil Biology and Biochemistry, 42, 1372-1384.

Zhou G, Liu S, Li Z et al. (2006) Old-growth forests can accumulate carbon in soils. Science (New York, N.Y.), 314, 1417. 


\section{Acknowledgements}

I would like to thanks all the persons that enable the writing of this thesis and to especially express my gratefulness to my supervisor Prof. Yakov Kuzyakov. Aside his support and the knowledge I gained from him during my $\mathrm{PhD}$ studies, I especially appreciated the freedom he gave me to conduct my $\mathrm{PhD}$, his patient and trust when I was presenting him my ideas and his reactivity to provide valuable feedback on short notice. Furthermore, I thank Prof. Daniela Sauer and Prof. Dirk Hölscher for evaluating my work.

I thank all the members of the CRC 990 that made this project a success. The time spent in Indonesia with all my fellow $\mathrm{PhD}$ students and friends was a highlight of my $\mathrm{PhD}$ studies. Being all together in Indonesia at the beginning of the project was a great help to understand the living in Indonesia and make a better field work. I appreciated the help of my Indonesian counterparts, especially Damris Muhammad, by showing us the way into their land, in the literal and figurative senses.

I have been impressed by the competences of my Indonesian assistant. Sujai Ahmad introduced me the tropical soils and their description. Toni Cranavo, helped by Muhammad Al-Muttaqii, made the DOC sampling possible. His independent and precise work was a great relief for me, who was supervising most of the time from Germany. With a more advanced knowledge in English and statistics, Indonesian students would have no difficulties to compete with international researchers.

I thank my student helpers, Thuy Loan Trinh, Huong Lê, Raffael Herth and Maire Holz for their precious help during the incubation experiment.

I appreciate to have found a friendly research group with researchers always ready to give a piece of advice and technicians always present to help for measurements or to help me finding my way in the laboratories. Spending time with my officemates, Sebastian Löppman and Per Schleuß was always a pleasure, at work and beside work. 
I am grateful that the friendship built with my former colleges at the University of Lausanne did lead to further collaboration during my $\mathrm{PhD}$ studies. I especially thank Remy Albrecht for introducing me to the FTIR and 3D fluorescence techniques and Prof. Eric Verrecchia for opening the doors of his laboratories and network.

Finally, I thank my family for their support, from the beginning to the end, and for enduring my "adventures" in foreign countries and receiving not enough any news from their son, brother or uncle.

Financial support for the research was provided by the German Research Council (DFG). 


\section{Appendix}

\subsection{Contribution to the studies}

Names order corresponds to the estimated importance of the each contribution

Study 1: Soil degradation in oil palm and rubber plantations under land resource scarcity

Study design: Thomas Guillaume, Anna Mareike Holtkamp, Yakov Kuzyakov, Bernhard

Brümmer

Sampling collection: Anna Mareike Holtkamp

Samples preparation and analysis: Thomas Guillaume, Muhammad Damris

Data Analysis: Thomas Guillaume

Data interpretation: Thomas Guillaume, Yakov Kuzyakov

Manuscript writing: Thomas Guillaume

Comments on manuscript: Yakov Kuzyakov, Anna Mareike Holtkamp, Bernhard Brümmer, Muhammad Damris

Study 2: Losses of soil carbon by converting tropical forest to plantations: Erosion and decomposition estimated by $\delta^{13} \mathrm{C}$

Study design: Yakov Kuzyakov, Thomas Guillaume

Sampling collection: Thomas Guillaume

Samples preparation and analysis: Thomas Guillaume, Muhammad Damris

Data Analysis: Thomas Guillaume

Data interpretation: Thomas Guillaume, Yakov Kuzyakov

Manuscript writing: Thomas Guillaume

Comments on manuscript: Yakov Kuzyakov, Muhammad Damris

Study 3: New approach for sensitivity of soil fertility indicators to land-use changes: Theory and examples from conversion of Indonesian rainforest to plantations 
Study design: Thomas Guillaume, Yakov Kuzyakov

Laboratory work: Thomas Guillaume, Deejay Maranguit

Data Analysis: Thomas Guillaume

Data interpretation: Thomas Guillaume, Yakov Kuzyakov

Manuscript writing: Thomas Guillaume

Comments on manuscript: Yakov Kuzyakov, Kukuh Murtilaksono, Deejay Maranguit

Study 4: Chemical characterization of soil organic matter

Study design: Thomas Guillaume, Remy Albrecht

Laboratory work: Thomas Guillaume (FTIR, 3D fluorescence), Remy Albrecht (FTIR), Thierry

Adatte (RE pyrolysis)

Data Analysis: Thomas Guillaume, Remy Albrecht

Data interpretation: Thomas Guillaume, Remy Albrecht, David Sebag

Study 5: Microbial response to easily available $\mathrm{C}$ input

Study design: Thomas Guillaume, Yakov Kuzyakov

Laboratory work: Thomas Guillaume

Data Analysis: Thomas Guillaume

Data interpretation: Thomas Guillaume, Jane Blagodatskaya, Yakov Kuzyakov

Study 6: Carbon translocation between topsoil and subsoil by dissolved organic mater

Study design: Yakov Kuzyakov, Thomas Guillaume

Sampling collection: Toni Cranavo, Muhammad Al-Muttaqii, Thomas Guillaume, Muhammad Damris

Data Analysis: Thomas Guillaume 


\subsection{Declarations}

1. I, hereby, declare that this Ph.D. dissertation has not been presented to any other examining body either in its present or a similar form.

Furthermore, I also affirm that I have not applied for a Ph.D. at any other higher school of education.

Göttingen,

(Signature)

(Name in block capitals)

2. I, hereby, solemnly declare that this dissertation was undertaken independently and without any unauthorized aid.

Göttingen,

(Signature)

(Name in block capitals) 


\subsection{Curriculum vitae}

Swiss

29.04.1983

Origin: Genève mobile phone : +491744633368

e-mail : tguilla@gwdg.de

Born in Lausanne

\section{Education}

- PhD candidate ; University of Göttingen

International Ph.D. Program for Agricultural Sciences

- Master in Biogeosciences ; University of Neuchâtel

10.2006-02.2009

Master Thesis: " Radioelements transfer from soil to plants"

- Advanced Studies in Biosafety and Plant Genetic Ressources Management

01.2008-11.2008

Universities of Genève and Lausanne

- Bachelor in Biology ; University of Lausanne

$10.2002-10.2005$

- Highschool, Biology/Chemistry; Gymnase August-Piccard (Lausanne)

08.1999-06.2002

\section{Professional experiences}

\section{- Laboratory scientist;}

University of Lausanne, Laboratory of Biogeosciences (Eric Verrecchia)

- Mathematic teacher;

Cycle d'orientation de Montbrillant, (Genève)

- Biology, physics and mathematics supply teacher;

Occasional replacement in secondary school (Genève)

- Project assistant ;

02.03.2009-30.09.2009

Unity of sustainable development, State of Vaud

\section{Internship}




\section{Conferences}

- $\quad$ EGU 2013: "Stock, turnover and functions of carbon in heavily weathered soils under lowland rainforest transformation systems", Thomas Guillaume and Yakov Kuzyakov; Poster

- Deutschen Bodenkundlichen Gesellschaft Jahrestagung 2013: "Properties and sequestration processes of carbon in heavily weathered soils under three lowland rainforest transformation systems", Thomas Guillaume and Yakov Kuzyakov; Poster

- $\quad$ BIOGEOMON 2014: "Assessing impacts of lowland rainforest transformation systems on soil organic matter and erosion using d13C"; Thomas Guillaume; Damris Muhammad and Yakov Kuzyakov; Poster

- International Symposium - Final Workshop CRC 990- Ecological and socioeconomic functions of tropical lowland rainforest transformation systems (Sumatra, Indonesia): "C cycle"; Thomas Guillaume et al.; Oral presentation

- $\quad$ EGU 2015: "SOC losses by converting tropical forest to plantations: Assessment of erosion and decomposition by $\delta 13 C$ approach"; Thomas Guillaume, Damris Muhammad and Yakov Kuzyakov; Oral presentation

- SUBSOM 2015: "Tropical forest conversion: SOC losses, erosion estimated by subsoil properties and effect on DOC"; Thomas Guillaume, Damris Muhammad and Yakov Kuzyakov; Poster

- Deutsche Bodenkundliche Gesellschaft Jahrestagung 2015 "Decrease of soil carbon stocks and availability by converting tropical forest to oil palm and rubber plantations, in Sumatra (Indonesia)" ; Thomas Guillaume, Damris Muhammad, Kukuh Murtilaksono and Yakov Kuzyakov; Oral presentation 